UNIVERSIDADE FEDERAL DE JUIZ DE FORA PROGRAMA DE PÓS-GRADUAÇÃO EM EDUCAÇÃO MATEMÁTICA MESTRADO PROFISSIONAL EM EDUCAÇÃO MATEMÁTICA

Alexandre Jenevain Junior

As concepções do professor de Matemática na sala de aula: como lidar com a diversidade dentro do espaço escolar?

Juiz de Fora

2020 


\section{Alexandre Jenevain Junior}

As concepções do professor de Matemática na sala de aula: como lidar com a diversidade dentro do espaço escolar?

Dissertação apresentada ao Programa de PósGraduação em Educação Matemática da Universidade Federal de Juiz de Fora como requisito parcial à obtenção do título de Mestre em Educação Matemática. Área de concentração: Educação Matemática.

Orientador: Marco Aurélio Kistemann Júnior

Juiz de Fora 
"As concepções do professor de Matemática na sala de aula: como lidar com a diversidade dentro do espaço escolar?"

Dissertação apresentada ao Programa de Pós-Graduação em Educação Matemática da Universidade Federal de Juiz de Fora como requisito parcial à obtenção do título de Mestre em Educação Matemática. Área de concentração: Educação Matemática.

Aprovada em 31 de março de 2021

\section{BANCA EXAMINADORA}
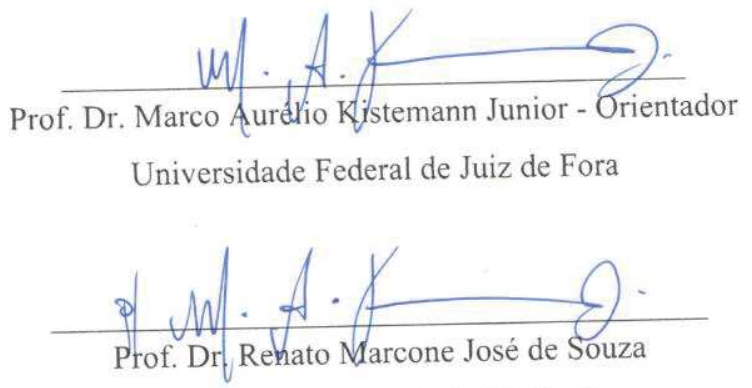

Universidade Federal de São Paulo

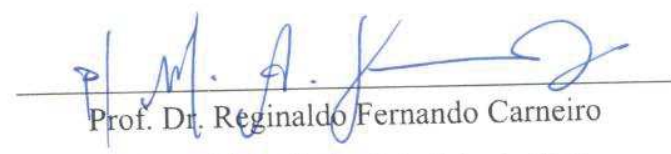

Universidade Federal de Juiz de Fora 
Dedico este trabalho a todas as pessoas que sofrem opressão por pertencerem a grupos minoritários, em nosso país. 


\section{AGRADECIMENTOS}

Agradeço, primeiramente, aos meus pais, por terem investido e incentivado minha busca por uma educação pública de qualidade, além de me apoiarem em todos os momentos da minha vida.

À minha irmã, pelos conselhos e por sempre mostrar-me novas direções.

Aos meus familiares, por sempre consolidarem um lugar acolhedor e dialogável em nossa família.

Aos meus amigos, por estarem presentes nos momentos de produção dessa dissertação.

Ao meu companheiro, por todas as vezes que mudou minha visão, quando eu achava impossível chegar a este dia.

Ao meu orientador, por ter apostado em minha proposta.

A todas as pessoas envolvidas na produção do produto audiovisual e a todas as pessoas que serão representados através deste trabalho, por resistirem todos os dias diante de uma sociedade tão esmagadora e preconceituosa. 
"Definitivamente não somos iguais, e é maravilhoso saber que cada um de nós que está aqui é diferente do outro, como constelações. $\mathrm{O}$ fato de podermos compartilhar esse espaço, de estarmos juntos viajando não significa que somos iguais; significa exatamente que somos capazes de atrair uns aos outros pelas nossas diferenças, que deveriam guiar o nosso roteiro de vida. Ter diversidade, não isso de uma humanidade com o mesmo protocolo. Porque isso até agora foi só uma maneira de homogeneizar e tirar nossa alegria de estar vivos." (KRENAK, 2019, p. 33). 


\section{RESUMO}

Considerando-se que a escola é um espaço plural e que diferentes sujeitos se constituem passando por esse lugar, esta dissertação buscou desnudar as concepções de docentes de Matemática a respeito de temas sociais que, normalmente, não são abordados na área de exatas. Para isso, com o auxílio da História Oral, entrevistamos licenciados em Matemática, na cidade de Juiz de Fora, estado de Minas Gerais, inseridos em três diferentes contextos educacionais: professores recém-formados, professores de escolas públicas e professores de escolas particulares. Visando a uma melhor coleta de dados, atentamo-nos para o fato de que nenhum entrevistado trabalhe em mais de um contexto ao mesmo tempo. Entendendo que abordaremos assuntos que passam por questões históricas e pessoais, convidamos todos os professores que tiverem acesso a essa dissertação para que, através deste trabalho, tenham um contato cuidadoso e tecnicamente preparado para temas como Racismo, Comunidade LGBTQIA+, Gênero e Sexualidade e Bullying e, além disso, saiam do lugar hierárquico e engessado que a nossa disciplina nos coloca, podendo, assim, em concomitância com o produto educacional, iniciarmos debates sociais e ampliarmos nosso entendimento sobre a diversidade que compõe o ambiente escolar.

Palavras-chave: Educação Matemática. Diversidade. Formação de Professores. Questões Raciais. Gênero e Sexualidade. Comunidade LGBTQIA+. 


\begin{abstract}
Considering that the school is a diverse environment and that different subjects are constituted also passing through this place, this dissertation sought to expose the preconceptions of Mathematics teachers regarding social themes that usually are not addressed in STEM. For this, with the aid of Oral History, we interviewed graduates in Mathematics, in the city of Juiz de Fora, state of Minas Gerais, inserted in three different educational contexts: recently graduated teachers, public school teachers and private school teachers. Aiming at a better data collection, we made sure that no interviewee was included in more than one of the aforementioned educational contexts. Understanding that we will address topics that go through historical and personal issues, we aim to provide Mathematics educators with work that was carefully and technically prepared to help them address topics such as Racism, LGBTQIA + Community, Gender and Sexuality and Bullying. In addition, we hope to leave the hierarchical and rigid place that our discipline places us, thus being able to, in conjunction with the educational product, initiate social debates and broaden our understanding of the diversity that make up the school environment.
\end{abstract}

Key-words: Math Education. Diversity. Racial Questions. Gender and Sexuality. LGBTQIA+ Community. 


\section{LISTA DE ILUSTRAÇÕES}

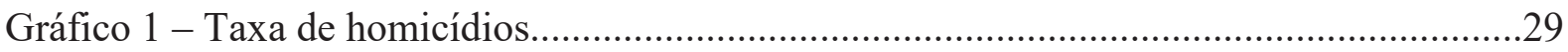

Gráfico 2 - Taxa ajustada de frequência escolar líquida da população residente de 6 a 24 anos de idade, segundo grupos de idade e nível de ensino. 


\section{LISTA DE TABELAS}

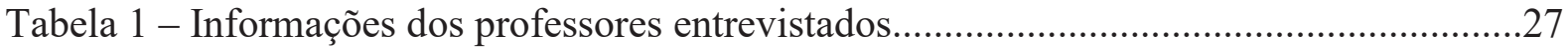




\section{LISTA DE ABREVIATURAS E SIGLAS}

IBGE Instituto Brasileiro de Geografia e Estatística

LGBTQIA+ Lésbicas, Gays, Bissexuais, Travestis, Transgêneros e Transexuais, Queer, Intersexuais, Assexuais e mais.

UNIFESP Universidade Federal de São Paulo

Ciep Centro Integrado de Educação Pública

ENEM Exame Nacional do Ensino Médio

BNCC Base Nacional Comum Curricular

UFRJ Universidade Federal do Rio de Janeiro 


\section{SUMÁRIO}

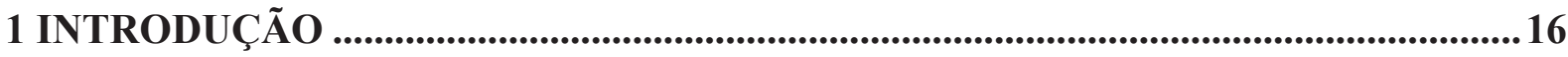

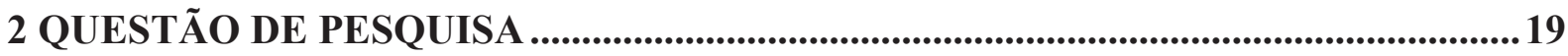

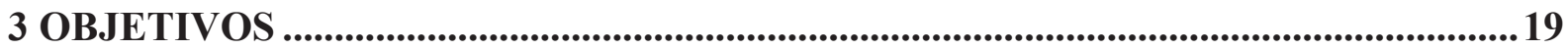

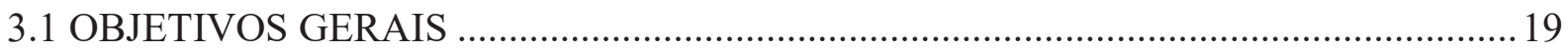

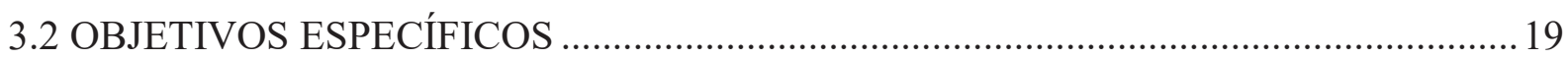

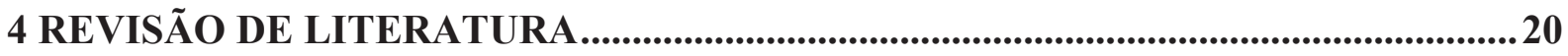

5 FUNDAMENTAÇÃO TEÓRICA............................................................................2

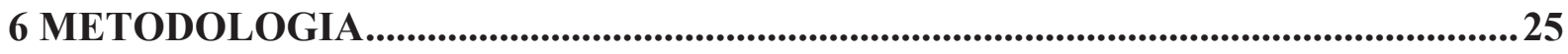

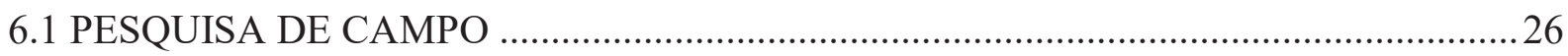

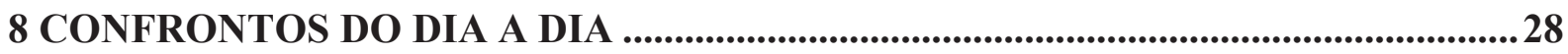

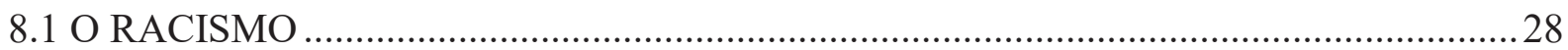

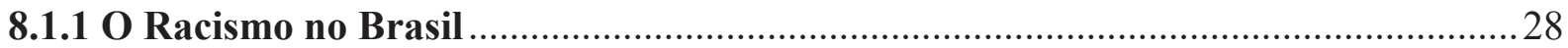

8.1.2 O racismo na concepção dos professores de Matemática ........................................ 32

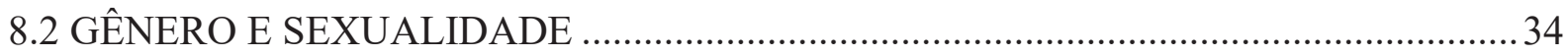

8.2.1 Gênero e Sexualidade na visão dos professores de Matemática: devemos abordar

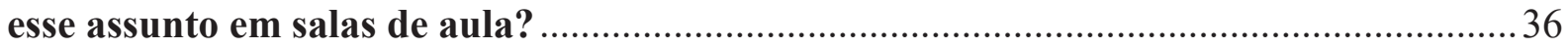

8.3 BREVE HISTÓRIA DO MOVIMENTO LGBTQIA+, DA SIGLA E DA LINGUAGEM

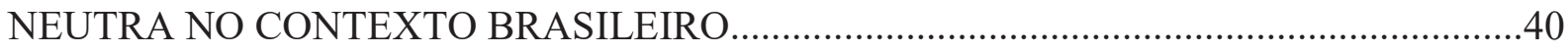

8.3.1 Confrontos entre a escola e a comunidade LGBTQIA+ através de relatos de

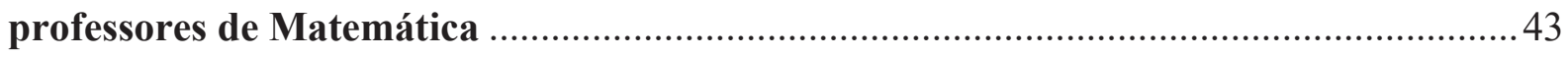

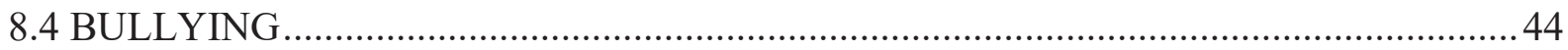

8.5 O INCENTIVO À CULTURA NAS ESCOLAS E A HIERARQUIZAÇÃO DA

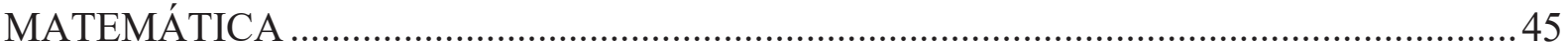

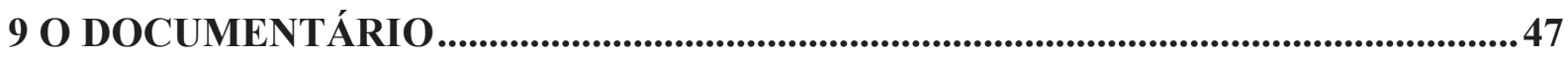

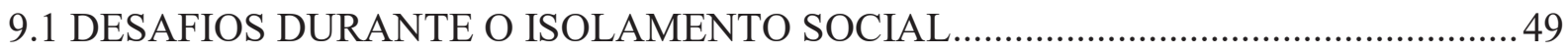

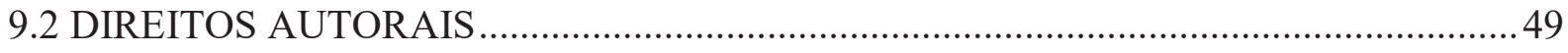

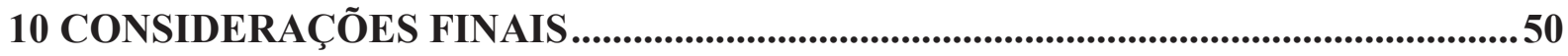


11 REFERÊNCIAS

APÊNDICE A - Pesquisas da CAPES relacionadas aos temas apresentados...................57

ANEXO A - Entrevistas Transcritas ........................................................................................59

ANEXO B - DOCUMENTÁRIO TRANSCRITO .......................................................114

ANEXO C - Termo de autorização de uso de imagem e voz ............................................. 122

ANEXO D - Direitos Autorais das Músicas..................................................................135 


\section{INTRODUÇÃO}

Desde que iniciamos nossa vida escolar, percebemos o quão difícil é conviver em sociedade. Quando crianças, somos inseridos em um ambiente próximo à realidade que temos em casa. As professoras são "tias", os alunos são "coleguinhas" e o contexto educacional vai se moldando com a finalidade de fazer sentirmo-nos pertencentes a um espaço já conhecido.

Contudo, viver em sociedade nos faz esbarrar em diversas classes sociais, pensamentos, ideais, etnias e religiões, e toda essa pluralidade coloca-nos em confronto com sentimentos desconhecidos. Sentir-se fora de sua zona de conforto pode não ser uma tarefa fácil, ainda mais quando falamos de alunos dos anos iniciais. A partir desse momento, podemos observar a construção da personalidade e dos pensamentos críticos de cada indivíduo e, com isso, devemos começar a levantar questões que abordem a diversidade presente na sociedade.

Infelizmente, ainda vemos lacunas nessa questão que, por sua vez, podem ser justificadas pelo despreparo dos professores ao lidar com essas realidades, oriundas da pouca formação oferecida em relação a esses temas e dos preconceitos enraizados em grande parte das pessoas gerando, assim, uma escassez de debates que visam a desconstruir alguns pensamentos sociais impostos ao longo do tempo.

Desde pequeno, fui amparado pela presença da minha família; alcancei boas notas e, consequentemente, criei uma ótima relação com meus professores. Mas, em minha trajetória escolar, faltou-me um afeto: entenderem-me como indivíduo. Comecei meus estudos em uma rede de ensino particular do meu bairro. Era perceptível o lugar onde eu me enquadrava, o de uma das crianças mais carentes desse colégio, em que tive minha vaga sustentada pelo suor dos trabalhos dos meus pais que, por sua vez, estendiam-se durante doze horas diárias. Lembro-me dos pedidos de desconto na mensalidade, por estarem sem dinheiro, mas de nunca deixarem de investir naquilo que achavam mais importante: minha educação. Nessa escola, comecei a conviver com diferenças sociais, ideológicas e políticas, fato que influenciou diretamente a formação da minha identidade.

Karl Marx ${ }^{1}$ levanta alguns pontos importantes sobre a educação e a formação da identidade. Entre eles, destaco:

\footnotetext{
${ }^{1}$ Karl Marx nasceu em 1818, na Alemanha. Foi um pensador dos elementos fundamentais do capitalismo enquanto sistema econômico, analisando suas formas de desenvolvimento, assim como a mercadoria, a moeda, o capital, o trabalho, a mais-valia, a acumulação de capital e as crises.
} 
A educação tem de assegurar o desenvolvimento integral da personalidade. Com a reaproximação da ciência e da produção, o ser humano pode tornar-se um produtor no sentido mais completo. Assim sendo, suas potencialidades podem ser reveladas e desenvolver-se. Todo um universo de necessidades vem à tona nessas condições, ativando o indivíduo em todas as esferas da vida social, inclusive o consumo, o prazer, a criação e o gozo da cultura, a participação na vida social, a interação com os outros seres humanos e a autorrealização. (BOTTOMORE, 2012, p.423).

Dessa forma, devemos assegurar, também, o desenvolvimento da personalidade e não somente o desenvolvimento intelectual dos alunos, o que não acontece, normalmente, justamente por não se abordar assuntos relacionados à diversidade, dentro dos ambientes escolares.

Minha segunda experiência escolar foi em uma escola da rede pública de ensino, onde ingressei no segundo ano no Ensino Fundamental devido à falta de recursos financeiros dos meus pais, dificuldade, esta, que impossibilitou minha permanência em uma instituição privada. É impressionante perceber como o contexto social mudou drasticamente. Dessa vez, eu era um aluno com uma das melhores situações financeiras daquele espaço e, para fundamentar essa percepção, lembro-me de um episódio em que uma amiga da escola veio em minha casa e comparou o tamanho da minha sala, afirmando ser o tamanho de toda a sua residência. Muitas vezes, meus amigos de turma iam às aulas somente para almoçar, uma vez que muitos alunos viviam em condições precárias, de extrema pobreza, faltando, inclusive, alimento em suas residências.

Nesse momento, eu não tinha maturidade suficiente para entender a dimensão de como essas realidades poderiam influenciar em nosso aprendizado, mas pergunto-me, hoje, se era imperceptível apenas para nós, estudantes, ou para todas as pessoas que compunham aquele espaço, visto que não me lembro de ter ocorrido algum tipo de intervenção em toda a minha vida educacional. Sabíamos sobre a existência desses problemas, mas a forma como lidar com eles não nos foi ensinado.

Esbarrando em outros problemas, vi-me imerso em minha fragilidade e em minha inocência. Todos os dias, alunos maiores queriam mostrar valentia contra os demais meninos da classe, e afetavam-me com ameaças e agressões. Durante meses, talvez anos, enfrentei tal situação sem nenhuma intervenção pedagógica, apenas com o suporte da minha família. Percebi, nesse momento, que as diferenças não só estão presentes, mas também influenciam diretamente todos os indivíduos. Além disso, de alguma forma, eu sentia-me diferente. Comecei a conviver com algo que eu, particularmente, só tomei consciência aos doze anos: 
minha orientação sexual. E a partir dessa percepção, fui tomando posse da minha identidade. Quando falo de identidade, recordo-me de uma citação do livro Identidade e diferença, organizado por Tomaz Tadeu da Silva:

[...] parece ser fácil definir "identidade". A identidade é simplesmente aquilo que se é: "sou brasileiro", "sou negro", "sou heterossexual", "sou jovem", "sou homem". A identidade assim concebida parece ser uma positividade ("aquilo que sou"), uma característica independente, um "fato" autônomo. Nessa perspectiva, a identidade só tem como referência a si própria: ela é autocontida e autossuficiente. Na mesma linha de raciocínio, também a diferença é concebida como uma entidade independente. Apenas, neste caso, em oposição à identidade, a diferença é aquilo que o outro é: "ela é italiana", "ela é branca", "ela é homossexual", "ela é velha", "ela é mulher". Da mesma forma que a identidade, a diferença é, nesta perspectiva, concebida como autorreferência, como algo que remete a si própria. A diferença, tal como a identidade, simplesmente existe. (SILVA, 2003, p. 74).

Fechando minha experiência escolar, exponho que mudei, mais uma vez, de instituição e fui matriculado em uma escola da rede estadual, chamada Escola Estadual Estêvão de Oliveira. Por ficar localizada em uma região central da cidade, pude perceber uma ampla divergência de contextos sociais. Nesse espaço, não cabia mais uma distinção de renda familiar, simplesmente, porque não era mais tão perceptível essa diferença.

Diante dos fatos por mim relatados até aqui, surgiu a necessidade de entender e de perceber como os professores de Matemática lidam com assuntos cotidianos considerados tabus, para analisar, a partir do produto educacional pretendido, meios de investir em uma melhor formação social por parte dos professores e, assim, buscar melhorar a realidade de muitos alunos que precisam desse apoio dentro do ambiente escolar.

Saliento que essa temática é escassa na área da Matemática, o que me permite destacar poucos pesquisadores formados em Matemática que abordam temas relacionados ao proposto por este projeto. Dentre eles, destacam-se o professor doutor Tomaz Tadeu da Silva, que escreveu o livro Identidade e Diferença, e a professora doutora Maria da Conceição Ferreira Reis Fonseca, em seu livro Relações de gênero, Educação Matemática e Discurso, em parceria com a professora doutora Maria Celeste Reis Fernandes de Souza, formada em Pedagogia e doutora em Educação. Além disso, podemos citar uma dissertação, da mestre Luiza Gabriela Razera de Souza, intitulada Quem calculava? Representações de gênero na relação mulher matemática na obra o homem que calculava de Malba Tahan. Até o momento, essas foram as únicas pesquisas de estudiosos formados em Matemática que relacionam a diversidade à presente proposta de dissertação. 
Por muitos anos, o ensino de Matemática foi fundamentado por profissionais que não se preocuparam em entender os contextos em que os alunos estão inseridos, diferentemente de outras licenciaturas, que englobam as áreas de Ciências Humanas e de Ciências Sociais. Como os professores estão em espaços nos quais a pluralidade existe, não podemos separar a ciência da parte social.

\section{QUESTÃO DE PESQUISA}

Por meio das perspectivas brevemente abordadas na introdução desta tese, emerge a necessidade de se elaborar uma questão que, por sua vez, norteie todo o conteúdo exposto neste trabalho, bem como sirva de base para que as respostas aos questionamentos relativos à abordagem teórica deste trabalho possam ser esclarecidas. Dessa forma, tem-se a seguinte pergunta-base para a temática desta dissertação: Quais as concepções de professores de Matemática em relação a alguns temas sobre a diversidade e a pluralidade dos estudantes em sala de aula?

\section{OBJETIVOS}

\subsection{OBJETIVOS GERAIS}

Desnudar as concepções de professores de Matemática a respeito de temas sociais que, normalmente, não são abordados na área de Exatas.

\subsection{OBJETIVOS ESPECÍFICOS}

1) Identificar as concepções dos professores de Matemática sobre diversidade e pluralidade.

2) Entender, de acordo com a realidade em que cada professor entrevistado está inserido, posicionamentos e atitudes quando confrontados, em suas salas de aula, com temas que, normalmente, não são discutidos nas aulas de Matemática.

3) Produzir um documentário audiovisual, a fim de auxiliar em uma possível formação de professores, visando, também, a abrir discussões sobre diferentes temas relacionados à diversidade e à pluralidade. 


\section{REVISÃO DE LITERATURA}

A revisão de literatura é extremamente importante para uma pesquisa, pois informa, aos leitores e aos profissionais, os estudos e as pesquisas relacionadas ao que se pretende apresentar.

Segundo Noronha e Ferreira,

Trabalhos de revisão são estudos que analisam a produção bibliográfica em determinada área temática, dentro de um recorte de tempo, fornecendo uma visão geral ou um relatório do estado-da-arte sobre um tópico específico, evidenciando novas ideias, métodos, subtemas que têm recebido maior ou menor ênfase na literatura especializada. Assim, a consulta a um trabalho de revisão propicia ao pesquisador tomar conhecimento, em uma única fonte, do que ocorreu ou está ocorrendo periodicamente no campo estudado. (NORONHA; FERREIRA, 2000, p.191).

Segue, portanto, a revisão de literatura realizada.

Iniciando a pesquisa, precisamos entender qual é a importância da relação entre família e escola na vida dos alunos. Segundo Janete dos Santos Reis, a boa relação famíliaescola constitui elemento importante para o processo de formação integral da criança. A família, embora venha passando por transformações, continua sendo uma instituição fundamental e de base para o desenvolvimento do ser humano. (REIS, 2013, p.9).

De fato, para acompanhar as mudanças nas rotinas dos estudantes, quando estes começam suas trajetórias escolares, é essencial que essa relação seja muito bem fundamentada. Concomitantemente, a formação da personalidade e da identidade dos alunos começa a tomar outras proporções. Quando convivemos em outros espaços e quando somos inseridos em novas realidades, nossa forma de ver o mundo sofre transformações.

Aproximamo-nos, então, daquilo que identificamos e, consequentemente, sentimo-nos - ou não - pertencentes a alguns grupos, sejam eles sociais, étnicos, religiosos, dentre outros, embora o fato de que, quando temos pouca idade, não temos consciência da dimensão e do impacto dessas inclusões ou exclusões. Quando adolescentes, porém, já observamos uma percepção mais profunda desses assuntos. A formação da identidade e a percepção das diferenças, portanto, demarca fronteiras, como disse Tomaz Tadeu da Silva, ao falar da produção social da identidade e da diferença:

Afirmar a identidade significa demarcar fronteiras, significa fazer distinções entre o que fica dentro e o que fica fora. A identidade está sempre ligada a 
uma forte separação entre "nós" e "eles". Essa demarcação de fronteiras, essa separação e distinção, supõem e, ao mesmo tempo, afirmam e reafirmam relações de poder. (SILVA, 2000, p. 03).

Afirmar e reafirmar relações de poder abre espaço para pensamentos de superioridade, fazendo com que muitas pessoas encarem algumas diferenças como algo inferior. Nesse momento, começa a opressão e o preconceito, ligados ao julgamento prévio, sem conhecer ou sem entender o modo de viver de cada um.

Nossa sociedade não oferece a mesma oportunidade a todos. Um aluno que vive em um bairro nobre e que estuda em uma rede de ensino particular pode ter acesso aos conhecimentos escolares de uma forma diferente, bem como a outras formas de cultura, como teatro, cinema, livros e exposições de arte, em comparação àqueles que moram e que estudam em bairros considerados periféricos, que sofrem a limitação desses acessos. Dulcineia Boscolo, em sua tese de doutorado, fala sobre a importância de reconhecer a diversidade no espaço escolar:

Reconhecer a diversidade existente no espaço escolar é fazer desse um meio de transformação, de busca da valorização da diferença e da singularidade de cada sujeito e, nesse sentido, o processo de incluir com sucesso um estudante exige o ato cauteloso de identificar as sutilezas de suas aprendizagens ao longo do caminho escolar. Ocorre que, devido à cultura escolar e ao sistema de ensino, os educadores, em certa medida e frequentemente, se eximem da responsabilidade de buscar compreender cada um de seus alunos e identificar a maneira como aprendem, para lhes oferecer o estímulo necessário à sua aprendizagem. O conhecimento geográfico, histórico, social e cultural do lugar é uma referência para compreender o aluno e a sua realidade. (BOSCOLO, 2018, p.159).

Em sua fala, Dulcineia expõe um ponto importante sobre cultura. Nesse aspecto,

Bourdieu (1993) traz dois conceitos: o primeiro deles é o de habitus:

É a sua posição presente e passada na estrutura social que os indivíduos, entendidos como pessoas físicas, transportam com eles, em todo tempo e lugar, sob a forma de habitus. Os indivíduos "vestem" os habitus como hábitos, assim como o hábito faz o monge, isto é, faz a pessoa social, com todas as disposições que são, ao mesmo tempo, marcas da posição social e, portanto, da distância social entre as posições objetivas, entre as pessoas sociais conjunturalmente aproximadas e a reafirmação dessa distância e das condutas exigidas para "guardar suas distâncias" ou para manipulá-las estratégica, simbólica ou realmente reduzi-las, aumentá-las ou simplesmente mantê-las (BOURDIEU, 1983, p. 75).

O outro conceito é o de capital cultural, evidenciado por Bourdieu em seu texto Os três estados do capital cultural (1979): 
O capital cultural pode existir sob três formas: no estado incorporado, ou seja, sob a forma de disposições duráveis do organismo; no estado objetivado, sob a forma de bens culturais - quadros, livros, dicionários, instrumentos, máquinas, que constituem indícios ou a realização de teorias ou de críticas dessas teorias, de problemáticas, etc.; e, enfim, no estado institucionalizado, forma de objetivação que é preciso colocar à parte porque, como se observa em relação ao certificado escolar, ela confere ao capital cultural - de que são, supostamente, a garantia - propriedades inteiramente originais. (BOURDIEU, 1979, p.02).

Considerando-se que o habitus faz a pessoa social e que o capital cultural de um indivíduo relaciona-se diretamente a esse habitus, é imprescindível perceber como esses termos regem nossa sociedade, tornando-se uma moeda que valoriza alunos que desempenham ações consideradas superiores, como, por exemplo, aqueles que apresentam uma aptidão maior para tocar um instrumento musical. Além disso, é constante uma segregação, ao considerar alunos mais ou menos inteligentes, de acordo com o desenvolvimento em áreas de exatas, ou até mesmo a percepção cultural de cada estudante, que pode ser justificada pelo acesso ou pelo não acesso a galerias de arte, museus, oportunidades de viagens, entre outros bens socioculturais

Dessa forma, a escola, a depender de fatores como localização e tipo de instituição, captura, também, o que seu corpo discente traz, adequando-se às suas necessidades, e podendo, assim, abrir espaço para uma defasagem de abordagem de assuntos sociais ou de assuntos que não se enquadram em seus objetivos principais. Com essa justificativa, restringimos nossa pesquisa às escolas brasileiras de ensino. Atentando para isso, decidimos focar essa revisão somente entre pesquisadores brasileiros, a fim de captarmos a realidade das pesquisas desses temas em nosso país. Achamos incoerente relacionar revisões de literatura de pesquisadores de outros lugares, diante da discordância entre realidades culturais, em comparação com o Brasil.

Pesquisando no banco de teses da CAPES, percebemos que não existem muitos trabalhos inter-relacionando Matemática e diversidade social, de gênero, cultural, étnica, racial, entre outras. Dessa forma, decidi filtrar a pesquisa em cinco eixos iniciais. São eles:

1. Educação Matemática e Escola sem partido: retornou um resultado.

2. Educação Matemática e Racismo: retornou um resultado.

3. Educação Matemática e Homofobia: retornou quatro resultados.

4. Educação Matemática e Sexualidade: retornou três resultados. 
5. Educação Matemática e LGBT: retornou cinco resultados.

$\mathrm{Na}$ análise inicial dos resultados encontrados, somente um demonstrou uma conexão entre uma obra de Matemática e um dos temas abordados nesse projeto, que é o de Gênero e Sexualidade. Essa pesquisa é da mestra Luiza Gabriela Razera de Souza, com o estudo intitulado Quem calculava? Representações de gênero na relação mulher matemática na obra o homem que calculava de Malba Tahan, já citado anteriormente. A tabela completa das pesquisas realizadas encontra-se no Apêndice A.

Diante da escassez de trabalhos, na educação matemática, que se relacionam aos temas, decidimos amparar nossa revisão em professores que já trabalharam com eles, ainda que não sejam professores de Matemática, para, então, buscar uma similaridade de ideias, com a finalidade de amparar os resultados esperados nessa pesquisa através de uma boa base teórica e, consequentemente, para findar a realização de um bom produto educacional.

\section{FUNDAMENTAÇÃO TEÓRICA}

A respeito do termo concepções, precisamos, antes, entender o conceito de construtivismo. Para Glaserfeld (1983), o construtivismo procura ultrapassar o dilema da primazia do sujeito ou da realidade do conhecimento, encarando este não como uma representação da realidade exterior, mas como constituindo a própria estrutura e organização da experiência. (GLASERFELD, 1983, p. 49).

Essa mesma fala de Glaserfeld está em um estudo intitulado Concepção dos Professores de Matemática e Processor de Formação, do autor João Pedro da Ponte. Nesse estudo, Ponte (1992) diz que o construtivismo é um ponto de vista geral, que inclui múltiplas correntes. Nesse mesmo trabalho, é exposto o que se entende sobre concepção:

[...] Elas constituem como que "miniteorias", ou seja, quadros conceptuais que desempenham um papel semelhante ao dos pressupostos teóricos gerais dos cientistas (Confrey, 1990, p. 20). As concepções condicionam a forma de abordagem das tarefas, muitas vezes orientando-nos para abordagens que estão longe de ser as mais adequadas. Estreitamente ligadas às concepções estão as atitudes, as expectativas e o entendimento que cada um tem do que constitui o seu papel numa dada situação (Ponte et al., em publicação). (PONTE, 1992, p. 08-09). 
Embora tenhamos estudos emergentes, o conceito de diversidade ainda é algo pouco explorado, no Brasil. Isso pode ser justificado observando-se a carência de definição dessa palavra, que é evitada, por muitos, nas abordagens de seus trabalhos. Mas, Thomas Jr. (1991) traz uma visão interessante acerca disso:

A diversidade inclui todos, não é algo que seja definido por raça ou gênero. Estende-se à idade, história pessoal e corporativa, formação educacional, função e personalidade. Inclui estilo de vida, preferência sexual, origem geográfica, tempo de serviço na organização, status de privilégio ou de nãoprivilégio e administração ou não administração (THOMAS JR, 1991, p.03).

Sabemos que ensinar Matemática esbarra em desafios pedagógicos, políticos, estruturais e cognitivos, e discorrer sobre metodologias alternativas para obter êxito nesse processo deve ser uma atividade contínua. Para distribuir melhor as áreas de pesquisa, a SBEM divide a Educação Matemática em grupos de trabalho, conhecidos como GT. Diante de todas as discussões por mim levantadas até esse momento, e depois de pesquisar e refletir, concluí que minha pesquisa de mestrado enquadra-se no GT13, possuindo como objetivo:

Agregar pesquisadores preocupados com o desenvolvimento de uma Educação Matemática "para todos", na qual as particularidades associadas as práticas matemáticas dos diferentes aprendizes são valorizadas e entendidas. Aborda pesquisas que buscam caminhos para uma cultura educacional que respeite a diversidade de aprendizes presente nos diferentes contextos educacionais, dentro e fora do contexto escolar. Contempla estudos que contribuem para uma compreensão profunda dos processos de ensino e de aprendizagem de matemática, focando questões culturais, teóricas, metodológicas, pedagógicas e epistemológicas. (SBEM, 2013).

Ainda pautado pela produção de uma dissertação de caráter social dentro da Educação Matemática, em Educação Matemática Crítica: a questão da democracia Skovsmose (2013), podemos encontrar inspiração para sustentar essa pesquisa:

O axioma básico da Educação Crítica é que a educação não deve servir como reprodução passiva de relações sociais existentes e de relações de poder [...]. A educação tem de desempenhar um papel ativo na identificação e no combate das disparidades sociais. Naturalmente, a educação não tem um papel importante nas mudanças sociais e tecnológicas - tais mudanças não são consequências de empreendimentos educacionais, mas a educação deve lutar para ter um papel ativo paralelo ao de outras forças sociais críticas (SKOVSMOSE, 2013, p. 32). 
Uma das formas mais eficazes de se produzir dados sobre as diversas realidades dos professores que ensinam Matemática, dos alunos e dos profissionais que participam do ambiente escolar, são as entrevistas. Segundo Ricardo Santiago e Valéria Barbosa de Magalhães:

\begin{abstract}
A fonte oral descortina o significado que eles tiveram para as pessoas que os viram ou vivenciaram e tanto os fatos quanto as percepções sobre tais acontecimentos são importantes na construção do conhecimento. Dessa maneira podemos coletar um material rico e verídico, uma vez que o próprio indivíduo compartilha suas experiências e vivências. (SANTIAGO; MAGALHÃES, 2015, p.25).
\end{abstract}

Por isso, utilizaremos a História $\mathrm{Oral}^{2}$, que ingressou no ambiente acadêmico brasileiro em 1970, e "se consagrou por ser não somente a história dos grandes homens, dos heróis, dos líderes, dos grandes políticos - mas, principalmente, por ser a história das pessoas comuns." (SANTHIAGO; MAGALHÃES, 2015, p.25).

\title{
6 METODOLOGIA
}

Essa é uma pesquisa de caráter qualitativo, com o objetivo de produzir um produto educacional no formato de um documentário audiovisual que desnude como os professores de Matemática lidam com temas e situações autênticas na sociedade, quando ocorrem dentro do espaço educacional.

Segundo Godoy (1995), a abordagem qualitativa oferece três diferentes possibilidades para se realizar uma pesquisa: a pesquisa documental, o estudo de caso e a etnografia. O estudo de caso caracteriza-se como um tipo de pesquisa cujo objeto é uma unidade que se analisa profundamente. Visa ao exame detalhado de um ambiente, de um simples sujeito ou de uma situação em particular.

Visando a analisar como os docentes de Matemática encaram temas sociais no ambiente escolar, decidimos entrevistar esses docentes, respeitando-se três contextos

\footnotetext{
${ }^{2}$ Um forte movimento de História Oral eclodiu, em nosso país, no início dos anos 1990, e teve a Associação Brasileira de História Oral fundada em 1994. Segundo SANTHIAGO, R.; MAGALHÃES, V. B (2015) a História Oral pode ser entendida de duas maneiras: como um método que registra memórias narradas, através de entrevistas, e como resultado desse método, isto é, como fonte de informação.
} 
principais: professores recém-formados, professores de escolas públicas e professores de escolas particulares - não havendo professores que trabalham em mais de um contexto ao mesmo tempo. Escolhemos essas restrições para coletar informações em realidades diferentes e em espaços plurais. Três professores foram entrevistados, e um professor foi criado a partir da minha própria experiência, seja como aluno, seja como professor. Este último irá compor somente o documentário, como personagem fictício, não influenciando a pesquisa e a veracidade dos dados dessa dissertação.

Como mencionado anteriormente, utilizamos a História Oral como ferramenta, ainda que não tenhamos passado por todos os processos que ela exige para fundamentar, de fato, uma metodologia. O livro História Oral na Sala de Aula (2015) dos autores Ricardo Santiago e Valéria Barbosa de Magalhães, norteia, de forma clara e objetiva, os passos para realizar uma boa coleta de dados. Nele, é aconselhado conhecer os equipamentos a serem utilizados: "Ainda mais importante que possuir o equipamento ideal, é saber manejá-lo. O entrevistador deve conhecer ao máximo as limitações, potencialidades e necessidades de seu equipamento" (BARBOSA; SANTIAGO, 2015, p. 89). Além disso, os autores mostram como agir no momento da entrevista:

Durante a entrevista, uma atitude de respeito e profundo interesse pela fala do outro - que naquele momento é o foco das atenções - é imprescindível. Além disso, são precisos certo desprendimento e jogo de cintura para que assuntos dolorosos e de difícil abordagem sejam tratados (BARBOSA; SANTIGAGO, 2015, p. 113).

Outros pontos levantados são importantes. Entre eles, como produzir dados ao tratar de diversos assuntos sociais e também os passos para uma boa análise do material coletado.

Os trechos das entrevistas serão expostos em cada capítulo, levando-se em consideração os temas conversados entre mim e os professores. A dissertação seguirá, então, um fluxo intercalado entre os estudos, os dados estatísticos e as vivências de autores acerca de cada assunto, em concomitância com a opinião dos docentes sobre a temática. As entrevistas transcritas completas estão no Anexo $A$, dessa dissertação.

\subsection{PESQUISA DE CAMPO}


Para preservar as identidades dos professores entrevistados, optamos pelo uso de nomes fictícios. As idades foram mantidas, em conformidade com os dados originais fornecidos nas entrevistas. Essas informações estão na tabela abaixo:

Tabela 1 - Informações dos professores entrevistados

\begin{tabular}{|l|c|}
\hline \multicolumn{1}{|c|}{ Professor(a) } & Idade \\
\hline Amanda Araújo & 31 \\
\hline Ivani Lima & 51 \\
\hline Marcelo Ferreira & 31 \\
\hline Henrique Coelho & 27 \\
\hline
\end{tabular}

Fonte: informações dos professores entrevistados.

A professora Amanda Araújo tem 31 anos, leciona em uma instituição na cidade de Juiz de Fora, e possui mestrado em Educação. Escolhemos essa professora, pois, em contato prévio, pudemos perceber seu engajamento em causas sociais e em atos políticos, utilizando a educação como ferramenta de inclusão e de defesa de minorias.

A professora Ivani Lima tem 51 anos, acabou de se formar em Licenciatura em Matemática, mas possui outra graduação, na área de Engenharia. Escolhemos essa professora, pois, em contato prévio, pudemos perceber posicionamentos diferentes dos da professora Amanda, gerando um contraponto de ideias.

O professor Marcelo Ferreira, na verdade, é a representação fictícia de uma professora entrevistada, de 31 anos, com vivência em uma instituição federal, durante o período de licenciatura, desenvolvendo, nessa época, atividades em monitoria, e atuando, também, como professora bolsista substituta, em alguns momentos, dentro dessa mesma instituição. Escolhemos essa professora, pois, em contato prévio, pudemos perceber seu engajamento em assuntos raciais, apresentando-se como uma mulher negra e militante em nossa sociedade.

O professor Henrique Coelho é fictício e aparecerá somente no produto educacional.

Todas as informações foram conferidas com os entrevistados, isto é, nenhuma opinião foi criada para apresentá-los, mas sim, uma descrição formada em conjunto. Não 
dizemos em qual contexto cada professor trabalha para evitar estereótipos, mas existe um de escola particular e dois de escolas públicas.

O capítulo seguinte dará enfoque a cada um dos temas abordados nas entrevistas, mostrando dados estatísticos e pesquisas de profissionais que vivenciam e estudam questões raciais, questões de gênero e sexualidade, aspectos da comunidade LGBTQIA+ e bullying. Além disso, existe um capítulo que se refere ao incentivo à cultura nas escolas brasileiras, à posição hierárquica das disciplinas, em especial o lugar de importância que a Matemática ocupa nas instituições, e ao que a Base Nacional Comum Curricular (BNCC) estabelece sobre o papel dos docentes nas salas de aula ao ensinar essa disciplina.

\section{CONFRONTOS DO DIA A DIA}

A partir deste momento, abordaremos, teoricamente, os temas norteadores das entrevistas. Em cada um deles, serão apresentados dados estatísticos, pesquisas e discussões sobre os assuntos, em concomitância com as opiniões dos professores que cederam as entrevistas acerca de cada temática proposta.

\subsection{O RACISMO}

Nesse capítulo, vamos falar sobre o racismo. Sim, precisamos falar sobre o racismo, assim como precisamos falar sobre os temas subsequentes. Os professores das áreas de Exatas não estão acostumados a abordar esse assunto, mas entendendo a escola como um lugar de pluralidade de ideias, de pensamentos, de ideologias, de religiões, de políticas, dentre outras questões, é fundamental que saiamos dos nossos lugares para buscar compreender o lugar do outro. Uma das professoras entrevistadas, Amanda Araújo, fez uma colocação interessante a respeito disso. Ela pontuou: "O quanto que a gente consegue se sensibilizar, questionar e problematizar quando toca a nossa pele, aquela coisa assim 'nossa eu senti na pele', e o quanto é um esforço muito grande para a gente conseguir sensibilizar quando toca a pele do outro. Se não sentir na pele, passa muito batido.”

\subsubsection{O Racismo no Brasil}


“Nunca entre em uma discussão sobre racismo dizendo, 'mas eu não sou racista'. O que está em questão não é um posicionamento moral, individual, mas um problema estrutural.” (RIBEIRO, 2019, p.13-14).

A fala da autora Djamila Ribeiro, filósofa, feminista negra, escritora e professora da UNIFESP, convida-nos a refletir sobre o contexto em que o nosso país está situado. De acordo com o informativo Estudos e Pesquisas - Informação Demográfica e Socioeconômica n.41, do IBGE, divulgado em 2019, mais da metade da população brasileira declara-se preta ou parda. Pretos e pardos são maioria em nosso país. Logo, deveríamos esperar que uma grande parte dos cargos gerenciais no mercado de trabalho estivessem ocupados por essa população. Entretanto, os dados mostram uma expressiva contradição. Em 2018, enquanto $68,6 \%$ dos cargos gerenciais, no Brasil, eram ocupados por brancos, somente 29,9\% deles eram ocupados por pretos ou pardos.

Outro dado alarmante é a taxa de homicídios por 100 mil habitantes. Em 2017, entre a população branca, essa taxa foi de 16,0. Já entre pretos e pardos, a taxa foi 43,3. Em outras palavras, uma pessoa preta ou parda tem 2,7 mais chances de ser vítima de homicídio intencional, quando comparada a uma pessoa branca. Além disso, um ponto que merece nossa atenção é o aumento dessa taxa entre pessoas pretas ou pardas, em comparação à taxa entre as pessoas brancas. Essa taxa manteve-se constante, como mostra o gráfico a seguir:

Gráfico 1 - Taxa de homicídios

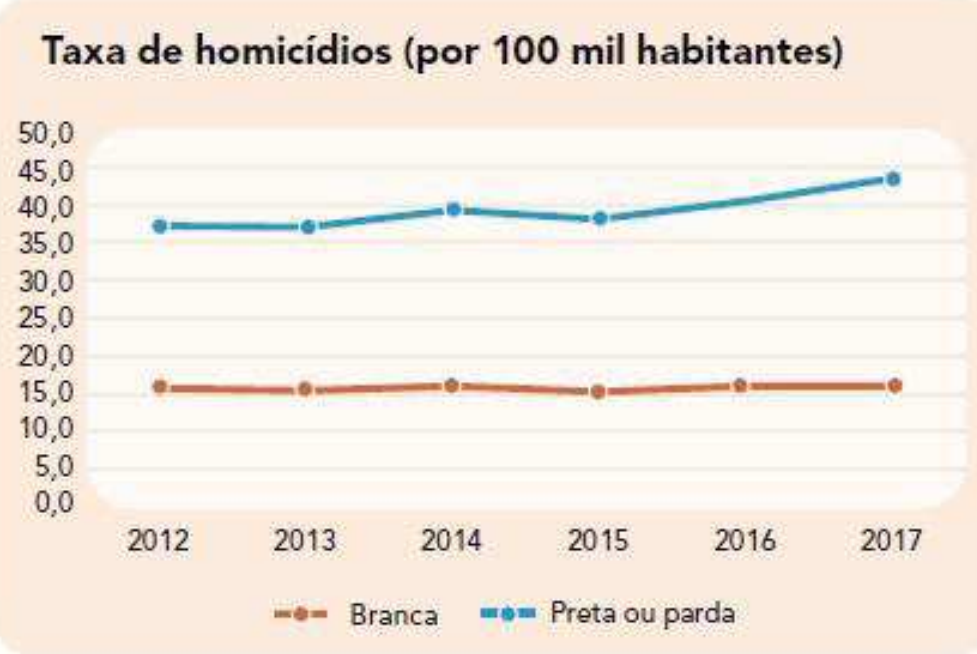

Fonte: Ministério da Saúde, Secretaria de Vigilância em Saúde e Sistema de Informações sobre Mortalidade - SIM. 
Quando falamos em educação, também percebemos uma diferença. Podemos observar, pelo gráfico abaixo, que, em 2018, todos os níveis de ensino eram ocupados, majoritariamente, por pessoas brancas:

Gráfico 2 - Taxa ajustada de frequência escolar líquida da população residente de 6 a 24 anos de idade, segundo grupos de idade e nível de ensino

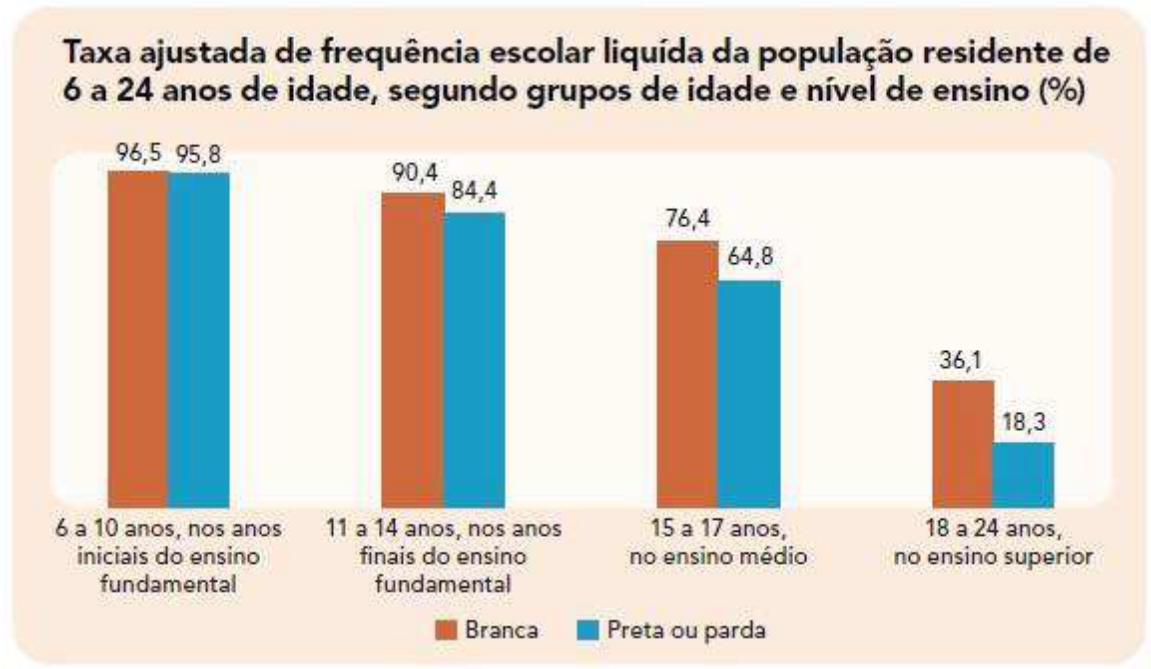

Fonte: IBGE, Pesquisa Nacional por Amostra de Domicílios Contínua 2018.

Em 2019, pela primeira vez na história, o número de negros matriculados em instituições de ensino superior ultrapassou o número de brancos matriculados nessas mesmas instituições. Segundo o IBGE, as matrículas de pretos e pardos, naquele ano, somaram 50,3\% do total de pessoas ingressantes em um curso superior.

Ao depararmo-nos com assuntos relacionados a grupos minoritários em direitos e em oportunidades, e ao entramos em debates que abordam, por exemplo, temas como racismo, homofobia e machismo, é relativamente normal escutarmos alguns termos. Analisando-se os dados mostrados anteriormente pelas pesquisas do IBGE, precisamos nos aprofundar em um termo conhecido como racismo estrutural, que vem aparecendo nas discussões, para explicar como se constituiu o racismo, em nosso país.

Segundo o advogado, filósofo e professor da Universidade Presbiteriana Mackenzie, Silvio Almeida, em seu livro Racismo Estrutural: 
O Racismo é uma decorrência da própria estrutura social, ou seja, do modo 'normal' com que se constituem as relações políticas, econômicas, jurídicas e até familiares, não sendo uma patologia social e nem um desarranjo institucional. O racismo é estrutural. Comportamentos individuais e processos institucionais são derivados de uma sociedade cujo racismo é regra e não exceção. $\mathrm{O}$ racismo é parte de um processo social que ocorre 'pelas costas dos indivíduos e lhes parece legado pela tradição'. Nesse caso, além de medidas que coíbam o racismo individual e institucionalmente, torna-se imperativo refletir sobre mudanças profundas nas relações sociais, políticas e econômicas. (ALMEIDA, 2019, p. 50).

Além do racismo estrutural, existe um outro termo recorrente, conhecido como lugar de fala. Segundo Djamila Ribeiro, para entendermos essa expressão, precisamos levantar os seguintes questionamentos: “'Quem pode falar?', 'O que acontece quando nós falamos?' e 'Sobre o que é nos permitido falar?"' (RIBEIRO, 2019, p.77). Seguindo essa mesma linha de pensamento, a autora ainda destaca, nessa mesma seção:

Esses questionamentos são fundamentais para que possamos entender lugares de fala. Dentro desse projeto de colonização, quem foram os sujeitos autorizados a falar? O medo imposto por aqueles que construíram as máscaras serve para impor limites aos que foram silenciados? Falar, muitas vezes, implica receber castigos e represálias e justamente por isso, muitas vezes prefere-se concordar com o discurso hegemônico como modo de sobrevivência? E, se falarmos, podemos falar sobre tudo ou somente sobre o que é permitido falar? Numa sociedade supremacista branca e patriarcal, mulheres brancas, mulheres negras, homens negros, pessoas transsexuais, lésbicas, gays podem falar do mesmo modo que homens brancos cis heterossexuais? Existe o mesmo espaço e legitimidade? Quando existe algum espaço para falar, por exemplo, para uma travesti negra, é permitido que ela fale sobre Economia, Astrofísica, ou só é permitido que fale sobre temas referentes ao fato de ser uma travesti negra? (RIBEIRO, 2019, p.77).

Entender, então, o conceito de lugar de fala é entender quem está falando, o que acontece com quem está falando e sobre o que é permitido que uma pessoa fale. Essas percepções esbarram diretamente em outras questões. A primeira é: o que é privilégio?

Privilégio não é sobre indivíduos sendo pessoas ruins, mas é sobre todo um sistema que favorece certos grupos e prejudica outros. Estes sistemas - como classismo, sexismo, supremacia branca etc. - tem apoio estrutural de leis, da mídia e de políticas que afetam nosso dia a dia. A maioria de nós não é ensinado sobre o quanto estes sistemas são uma parte influente no modo como o mundo funciona. (JOHNSON, 2015, p. 5). 
Em nossa sociedade, uma das questões que podem ser levantadas sobre o que é ser privilegiado, a meu ver, é ter o direito de falar, em qualquer espaço, sem que nada de negativo aconteça.

Um outro conceito importante, já citado por Jhonson anteriormente, é o de supremacia branca. Acrescentando-se aos estudos, podemos citar Almeida (2019, p. 75): “A supremacia branca é uma forma de hegemonia, ou seja, uma forma de dominação que é exercida apenas pelo exercício bruto do poder, pela pura força, mas também pelo estabelecimento de mediações e pela formação de consensos ideológicos.”.

Agora que sabemos um pouco mais sobre o racismo, vamos analisar o que pensam os professores de Matemática sobre esse assunto.

\subsubsection{O racismo na concepção dos professores de Matemática}

Como pudemos ver, a pesquisa de campo dessa dissertação consistiu em entrevistar alguns professores que possuem diferentes vivências educacionais. Buscamos abranger, na primeira parte da entrevista, temas relacionados às questões raciais na sala de aula. Para isso, levantamos a primeira questão: Devemos falar sobre o racismo na sala de aula de Matemática?. A partir dela, a professora Ivani Lima respondeu:

Acho que as coisas têm que ser ditas naturalmente e, principalmente, eu acho que é a educação infantil a primeira educação, quando as coisas começam a se formar na cabeça dos alunos. As diferenças têm que ser apontadas na infância. O seu olhinho é diferente do olhinho dele, a sua sobrancelha diferente, o seu ombro é diferente, a sua altura é diferente, o tipo de rosto é diferente, os dedinhos são diferentes...entendeu? Eu acho que falta isso muito na escola básica do Brasil." A professora ainda destaca: "se isso fosse trabalhado na infância normalmente, não somente a cor da pele, eu acho que seria um detalhe.

Já de acordo com o professor Marcelo Ferreira, o racismo não é falado como o feminismo ou como as questões LGBTQIA+: “[...] ainda é muito tabu se falar sobre racismo. É muito tabu, ainda é muito mal visto; quem fala, quem se posiciona. E é uma coisa que é recorrente, "tá" no imaginário brasileiro. E as pessoas acham que são casos isolados, mas não são casos isolados. É uma coisa constante [...]". Ele continua e diz: "tem que haver um esforço pessoal de desconstrução em todos esses aspectos, e minha desconstrução veio muito por conta do meu cabelo.”. 
A professora Amanda Araújo, por sua vez, faz uma colocação interessante à respeito desse tema, quando indagada sobre a presença de negros em seu local de trabalho e sobre os lugares que eles ocupam. Segundo ela, ainda é um ambiente escasso: "Minorias, sempre. Sempre minorias. Há a presença de figuras que ocupam esse lugar da representatividade, mas elas ainda em minoria quantitativa, ainda ocupando um espaço de minoria, porque são muito sufocadas pelo dito e pelo não dito, pelo feito e pelo não feito, pelo que fica nas entrelinhas, pelo que é escancarado... Então, é um espaço carente, sim, e é um espaço que, assim, aí quando a gente vai pensar nisso, a gente pensa assim: "por que ainda é carente? Porque gente, enquanto nação, olha quanto tempo que a gente vem se constituindo, enquanto democracia, olha quanto tempo que a gente vem se constituindo, enquanto, direitos humanos, enquanto tantos debates já 'tão' aí há tanto tempo, mas, né, tem muitas forças que elas querem amarrar no chão mesmo, né? Aí, essa briga de forças.”.

O professor Marcelo Ferreira foi além e disse que, em seu trabalho, já vivenciou situações de racismo: "No meu local de trabalho, eu já vi situações; já vi situações em sala de aula, muitas situações - tanto comigo, quanto com outras pessoas - e é isso, assim. Até, por exemplo, motorista de Uber. Qualquer lugar, em qualquer momento. Como é uma sociedade extremamente racista, então, é mais fácil a probabilidade de você encontrar um racista no meio da rua é muito grande. Então, é algo como uma subjetividade coletiva que paira, né, a partir de uma cultura que foi construindo essa ideia.".

Quando questionada sobre o sistema de cotas, a professora Ivani Lima respondeu que é a favor da cota social, porque "a cota social iria entrar todos os negros de baixa renda, entendeu? Que tivesse escalas - eu nunca estudei sobre isso, eu não sei como eu faria isso. Mas, eu sei que tem erros sérios. Do jeito que 'tá', não deveria existir'. A professora continua argumentando que "um branco pobre, hoje, quase que impossível entrar numa faculdade".

Para finalizar a parte sobre racismo com os professores, perguntei para cada um deles: você acha que devemos falar sobre racismo na sala de aula de Matemática?. A professora Ivani Lima acha todos os assuntos "extremamente naturais, e isso vem naturalmente, por quê? Porque primeiro que eu acho muito difícil existir um branco nato, né? Já não existe, na sociedade, mais um branco nato.”.

Já o professor Marcelo Ferreira foi enfático: "não necessariamente, talvez, falar sobre racismo. Talvez, como o momento pede, eu acho que é fundamental que se fale. Mas, pensando, assim, numa sociedade que já superou isso, eu acho que o ideal seria, 
simplesmente, sempre contextualizar momentos históricos, contextualizar dados, sabe? Contextualizar as coisas e discutir, abrir sempre discussão sobre isso.”.

\subsection{GÊNERO E SEXUALIDADE}

Inicialmente, como professor de Matemática, pesquisei sobre os discursos relacionados às masculinidades que rodeiam minha área. Segundo o livro Relações de gênero, Educação Matemática e discurso,

o discurso da superioridade masculina em matemática que produz a racionalidade como própria do masculino, e a irracionalidade como própria do feminino, multiplica-se em nossa sociedade moderna, associando-se a enunciados de outros campos. Associam-se, por exemplo, a algumas interpretações sobre as diferenças entre mulheres e homens que se apoiam no campo da biologia, explicando que tais diferenças se produzem organicamente. (SOUZA; FONSECA, 2010, p.62).

Podemos fazer uma analogia com o relato da professora Amanda, em sua entrevista: "no ambiente de trabalho, eu já vivi anos em um mesmo ambiente de trabalho, em que eu não conseguia falar em reunião nenhuma. Eu não conseguia falar, porque a partir do momento que eu abria a boca, havia uma figura que levantava a voz pra falar mais alto, junto comigo, e sobre outro assunto. E havia uma força nessa figura e nessa postura assumida que eu nunca conseguia terminar o meu raciocínio; às vezes, eu não conseguia nem começar a falar direito. Então, eu passei por isso durante muitos anos, sabe? E 'tô' nomeando como uma figura, mas era a figura de um homem branco, da área de Exatas, heterossexual, cristão, cisgênero, com mais experiência, com mais títulos acadêmicos.".

O curioso é observar que, historicamente, as mulheres são maioria no magistério e nas licenciaturas. Segundo dados do censo escolar 2017, as mulheres são maioria na educação básica, representando $80 \%$ de todos os docentes.

Para tentar entender por quê mulheres são silenciadas em um espaço majoritariamente composto por elas, precisamos analisar como a dicotomia do masculino e do feminino constitui as relações da nossa sociedade:

O esquema binário que situa o masculino e o feminino como categorias excludentes estende-se para definições do que é ser homem e do que é ser mulher, professor e professora em nossa sociedade. Essa dicotomia cristaliza concepções do que devem constituir atribuições masculinas e femininas e 
dificulta a percepção de outras maneiras de estabelecer as relações sociais. $\mathrm{O}$ cuidado, por exemplo, é visto como uma característica essencialmente feminina (VIANNA, 2001, p. 93).

Essas construções do "ser homem" e de "ser mulher", em nossa sociedade, esbarram diretamente no conceito de gênero. Guacira Lopes Louro, doutora em Educação e professora titular aposentada da Universidade Federal do Rio Grande do Sul, em seu livro Gênero, Sexualidade e Educação (2003, p.25) diz que "Ao afirmar que o gênero institui a identidade do sujeito (assim como a etnia, a classe, ou a nacionalidade, por exemplo) pretende-se referir, portanto, a algo que transcende o mero desempenho de papéis, a ideia é perceber o gênero fazendo parte do sujeito, constituindo-o.”.

Considerando, então, o que foi exposto por Vianna (2001) e por Louro (2003), podemos perceber que, embora nossa atenção não deva se restringir somente a gênero como o papel por nós exercidos na sociedade, a forma como o gênero nos constitui como sujeitos pode influenciar diretamente nos lugares que ocupamos nessa mesma sociedade.

Mas, com a evolução das discussões sobre gênero, emerge um outro conceito extremamente importante para o nosso entendimento das construções dos sujeitos: o conceito de sexualidade.

Ainda segundo Louro:

[...] os sujeitos podem exercer sua sexualidade de diferentes formas, eles podem "viver seus desejos e prazeres corporais" de muitos modos (Weeks, apud Britzman, 1996). Suas identidades sexuais se constituiriam, pois, através das formas como vivem sua sexualidade, com parceiros/as do mesmo sexo, do sexo oposto, de ambos os sexos ou sem parceiros/as. Por outro lado, os sujeitos também se identificam, social e historicamente, como masculinos ou femininos e assim constroem suas identidades de gênero. Ora, é evidente que essas identidades (sexuais e de gênero) estão profundamente interrelacionadas. (LOURO, 2003, p.26-27).

Constatamos, então, a sexualidade como algo inter-relacionado ao gênero e às questões sociais, mas trata-se, também, de algo individual. Está diretamente ligada à forma de nos relacionarmos afetivamente, amorosamente e emocionalmente.

Para entendermos melhor como esse tema é tratado entre os docentes de Matemática, vamos analisar as posições defendidas pelos professores entrevistados acerca do tema gênero e sexualidade na sala de aula. 


\subsubsection{Gênero e Sexualidade na visão dos professores de Matemática: devemos abordar esse assunto em salas de aula?}

Esse capítulo começará com uma experiência pessoal, na qual tive a oportunidade de levar o tema gênero e sexualidade para um colégio particular e católico, durante uma proposta de aula, em uma disciplina cursada no mestrado. Gosto de enfatizar que é uma instituição particular e católica para mostrar que, aos poucos, podemos ocupar espaços inicialmente inimagináveis. O referido colégio fica localizado na cidade de São Gonçalo, estado do Rio de Janeiro. Com 91 anos de história, é um dos colégios mais tradicionais da região. Para minha feliz surpresa, fui extremamente bem acolhido. Trabalhei com uma turma de estudantes do segundo ano do Ensino Médio, através da plataforma Google Meet, na qual quarenta e três alunos estiveram presentes.

Minha proposta foi baseada em uma junção entre a Matemática e um tema social. É evidente perceber, ao ver um jornal ou ao navegar pela internet, por exemplo, que os gráficos, as tabelas e os números percentuais são importantes marcadores de informação e de interpretação. Nesse sentido, podemos destacar a Literacia Estatística:

A literacia estatística refere-se ao estudo de argumentos que utilizam a estatística como referência, ou seja, à habilidade de argumentar usando corretamente a terminologia estatística. Entendemos que a literacia estatística inclui também habilidades básicas e importantes que podem ser usadas no entendimento de informações estatísticas. (CAMPOS; WODEWOTZKI; JACOBINI, 2011, p.23).

Findando gerar dados estatísticos com os estudantes, a fim de eles analisarem a produção entendendo a construção desses processos, construí um questionário com algumas questões que envolvem Gênero e Sexualidade, através da ferramenta Google Forms. Enviei esse questionário à professora regente da turma, com quinze dias de antecedência à aula, para que os estudantes pudessem responder. Vinte e seis pessoas responderam às perguntas. Um recurso interessante do Google Forms é a apresentação de gráficos gerados a partir dos resultados obtidos nas respostas. Qual é sua identidade de gênero?, Qual é sua orientação sexual?, Você sabe qual é a diferença entre sexo biológico, identidade de gênero e orientação sexual? e Algum professor de Matemática já abordou esse assunto em sua escola?, foram algumas das perguntas presentes nesse material. 
O primeiro momento da aula foi composto por uma breve introdução ao tema proposto e também por uma explicação acerca dos termos presentes nas questões por mim levantadas, o que poderia ter gerado dúvidas entre os estudantes. Feito isso, iniciamos a análise dos dados e levantamos alguns pensamentos para possíveis discussões.

Para minha surpresa, os estudantes não apresentaram dificuldades com nenhum termo. Eles sabiam o que significava ser cisgênero e transgênero, assim como o tipo de atração emocional, física e afetiva de cada orientação sexual, por exemplo. Inclusive, nessa turma, existem pessoas que já se percebem e se entendem como não-binárias e também como não-heterossexuais.

Em relação às discussões, existem dois pontos de destaque: o primeiro ponto que me chamou a atenção foi que um estudante disse, ao responder à pergunta qual é sua orientação sexual?, que "não tinha se definido ainda". Durante a aula, conversamos sobre a necessidade de que os indivíduos têm de afirmar, a todo momento, para a sociedade, diversos aspectos de suas vidas. Um deles relaciona-se ao fato de haver uma certa pressão por deixar claro ou por justificar o porquê de nos sentirmos atraídos afetivamente e emocionalmente por alguém. Para minha surpresa, o mesmo estudante retirou o "ainda" de sua resposta, deixando-a somente como "eu não me defini". Considero de grande valia para reflexão esse episódio, pois, ao se retirar a ideia temporal que a palavra "ainda" traz, tal fato mostra-nos que essa discussão pôde, de certa forma, ter tirado o peso de, em algum momento, ter que expor, para a sociedade, nossa orientação sexual e, consequentemente, com quem vamos nos relacionar.

O segundo ponto importante foi perceber que o problema de não abordar questões de gênero e sexualidade dentro dessa escola não está nos estudantes ou em como eles vão lidar com esse tema. Pessôa, Pereira e Toledo (2017), escreveram um trecho que considero cabível para uma possível generalização. Segundo esses autores:

[...] em sua maioria, o problema de não abordar o assunto dentro das escolas está em seus gestores, professores e familiares, mas não nos alunos. Talvez o maior desafio que enfrenta o professor quando lida com questões que se referem a gênero e sexualidade, seja justamente a necessidade de romper com os seus próprios paradigmas, de se colocar num processo contínuo de desconstrução e reconstrução de valores socialmente construídos (muitos dos quais historicamente superados, modificados e sem sentido). A primeira questão sobre gênero e sexualidade com a qual o professor precisa lidar na escola refere-se ao conflito que pode haver entre o seu papel como o profissional que deve garantir o respeito e a compreensão relativos à diversidade de valores, crenças, condições e escolhas de outrem e as suas 
escolhas pessoais, que não devem ser apregoadas a ninguém, mas aceitas e respeitadas como as de qualquer outra pessoa. Para ser professor e enfrentar os desafios da educação atual, será preciso enfrentar-se a si mesmo. (PESSOA; PEREIRA; TOLEDO, 2017, p. 28).

Continuando essa questão, em seu livro Formação Continuada de Professores: Gênero e Sexualidade na Rede Municipal de Juiz de Fora, Ana Cristina Ferreira dos Santos, mestra em Educação e professora da rede municipal de ensino da cidade de Juiz de Fora, faz uma colocação interessante sobre a falta de abordagem de assuntos relacionados a Gênero e Sexualidade nas escolas. Segundo ela, "o silêncio tem sido uma estratégia para ocultar e negar a sexualidade presente na vida da sociedade pela escola.” (SANTOS, 2017, p.97). Nessa perspectiva, a autora reitera que "[...] mais do que pensar sobre práticas sexuais, a educação que se pretenda para a sexualidade é tornar os alunos capazes de vivencias sua sexualidade de forma consciente. Tentar esconder a sexualidade ou silencia-la é uma impossibilidade no atual contexto da sociedade." (SANTOS, 2017, p.97).

A Universidade Federal de Juiz de Fora oferece uma disciplina intitulada Gênero, Sexualidade e Educação. Para a produção desta dissertação, assisti a algumas de suas aulas. O docente que as ministrava disse que eu era o seu primeiro aluno da Matemática. Contudo, essa matéria tornou-se uma eletiva para a Pedagogia e, mesmo que não seja obrigatória para outras licenciaturas, como em História e Sociologia, por exemplo, muitos alunos desses cursos fazem essa disciplina. Resolvi expor essa situação para percebermos que a falta de incentivo não é somente dos pais ou dos gestores da educação básica, mas também das grades curriculares das licenciaturas da área de Exatas.

Analisando-se as falas dos entrevistados, a professora Amanda Araújo, disse que “por muito tempo, via a escola como um 'sacro-lugar'; separado, santificado, protegido, e não é assim". Hoje, ela diz que enxerga a escola como um "recorte da sociedade", afirmando ser "um dos espaços da sociedade".

Outras indagações podem fazer-nos pensar sobre a defasagem de se tratar assuntos sociais na Matemática. Segundo Godoy (2020), uma parte da população de docentes e de futuros membros dessa comunidade que, por sua vez, lecionarão a Matemática escolar considera que a contextualização e a interdisciplinaridade devem ser associadas à história da Matemática, às Ciências da Natureza e às Engenharias, mas não às Ciências Humanas.

Através da análise de dados dos professores de Matemática, observamos que as opiniões sobre gênero e sexualidade, nas escolas, divergem. 
Para a professora Amanda, "existe uma tendência muito forte, especialmente se fortalecendo nos últimos anos, não à toa, de diminuir o pouquíssimo espaço que já havia sido conquistado". Complementando sua fala, a professora deixa o relato de uma experiência que viveu: “[...] esse ano aconteceu uma situação numa outra turma de Ensino Fundamental; não é restrito ao Ensino Fundamental, é que eu 'tô' me lembrando, agora, de uma agressão verbal, de uma violência, na verdade, uma violência verbal, de um grupo de meninos contra um grupo de meninas, e essa violência verbal baseava, em, vamos dizer assim, partia dos meninos, em colocar aquelas meninas num lugar de 'quaisquerzinhas'. O termo usado foi isso, foi 'suas quaisquerzinhas', no sentido de que tem um lugar da mulher que é valorizado e um outro lugar da mulher que é diminuído". Amanda disse que apresentou uma proposta de intervenção diante dessa situação. Essa proposta consistiu em pesquisar sobre mulheres que contribuíram, de alguma forma, para o desenvolvimento científico mundial e, posteriormente, apresentar os resultados encontrados para toda a turma.

A professora Ivani pensa que o tema gênero e sexualidade deve ser abordado em sua sala de aula, mas "tem que ter amparo de pessoas que realmente entendem do assunto". "Então, se você não sabe tudo, cala, para, - 'olha, isso é um assunto, realmente, que eu não sei.' - Entendeu? Então, o que eu vejo, hoje, é que todo mundo quer dar o 'pitaco' e saber de tudo e não sabe.".

Já para o professor Marcelo, "o ser humano é muito complexo, ele é muito complexo, sabe? E muito plural. E ninguém cabe nas caixinhas que sempre nos deram de ser homem, de ser mulher, de família. Ninguém cabe nessas caixinhas, sabe? E, aí, tentam constantemente aparar as arestas pra que você encaixe naquele lugar. Isso não existe. E, hoje, a gente sabe que, na ciência, a diversidade é fundamental; é fundamental pra pensamentos diferentes, visões diferentes, experiências diferentes que enriquecem muito. Pesquisas e, né? Todo o conhecimento científico. É fundamental a diversidade. Então, sim, com certeza."

Existe a ideia de que falar sobre gênero e sexualidade nas escolas é sinônimo de "ensinar e incentivar os estudantes a fazerem sexo". Sobre isso, o professor Marcelo disse que não concorda. Segundo ele, “[...] é uma coisa bem diferente, o fazer, né, o ato sexual, da sexualidade. E a sexualidade, ela abarca a questão do corpo, do conhecimento do seu próprio corpo e, também, de saber se defender, de saber o que que pode e o que que não pode, sabe? A gente vê, aí, também, por exemplo, quantas crianças... Então, casos de abuso que são denunciados justamente porque a criança não sabe o que é. E é aquela coisa, gente, criança não é de pai e de mãe, não é de família. Criança é do mundo, somos seres do mundo, sabe? A 
gente tem que ser criado pro mundo. E muitos valores familiares, muitas vezes, estão completamente deturpados e errados, e isso afeta toda uma sociedade. Então, é muito fundamental, também, falar de gênero e sexualidade.”

\title{
8.3 BREVE HISTÓRIA DO MOVIMENTO LGBTQIA+, DA SIGLA E DA LINGUAGEM NEUTRA NO CONTEXTO BRASILEIRO.
}

O movimento LGBTQIA+, no Brasil, sofreu resistências específicas para poder, de fato, emergir e instaurar-se socialmente. Isso porque enquanto alguns países do mundo já observavam o aparecimento de grupos rebeldes - compostos por jovens homossexuais, principalmente após o ano de 1969, no qual podemos citar, como inspiração para essa nova onda de protestos, a Rebelião de Stonewall ${ }^{3}$ - nosso país vivia uma fase controlada por um poder beligerante: a Ditadura Militar.

\begin{abstract}
A sexualidade passou a ser, em certa medida, tema pertinente à segurança nacional para os militares. Os desejos e afetos entre pessoas do mesmo sexo também foram alvo do peso de um regime autoritário com pretensão de sanear moralmente a sociedade e forjar uma nova subjetividade à imagem e semelhança da família nuclear, monogâmica, patriarcal e heterossexual. (GREEN; QUINALHA; CAETANO; FERNANDES, 2018, p. 10).
\end{abstract}

Com a finalidade de controlar a população, o período da ditadura censurava cenas em novelas, músicas em rádios e peças de teatro que, de alguma forma, pudessem despertar um pensamento contestador e incentivar uma possível rebelião.

O regime implantado em 1964 contribuiu também para a generalização de uma prática de pressão psicológica que podemos chamar de "lavagem cerebral", que consistia num conjunto de pressões exercidas sobre determinadas pessoas com tal intensidade, que lhes acarretava uma espécie de desestruturação da personalidade e acabando por induzi-las a aceitar passivamente, determinadas orientações de comportamento (DE OLIVEIRA, 2003, p. 30).

Foi no final da década de 1970 que a censura perdeu um pouco sua força, dando lugar ao surgimento de um importante jornal na cidade do Rio de Janeiro: O Lampião.

\footnotetext{
${ }^{3}$ Rebelião de Stonewall: o início da história da luta por direitos da comunidade LGBT, por vezes, é atribuído às manifestações contra a invasão do bar Stonewall Inn, no episódio que ficou conhecido como "rebelião de Stonewall" (APOLINÁRIO; MANFREDINI; GRALAK; MINATOGAWA; PERRONI, 2019, p. 97).
} 
Este era editado no Rio de Janeiro por jornalistas, intelectuais e artistas homossexuais e distribuído por todas as bancas do país. Seus editores pretendiam originalmente não só lidar francamente com a homossexualidade, como também forjar alianças com outras "minorias" com reivindicações específicas, como os negros, feministas, índios e representantes do movimento ecológico. (GREEN; QUINALHA; CAETANO; FERNANDES, 2018, pg.42).

A partir desse momento, alguns grupos surgiram a fim de discutir assuntos que envolvem a homossexualidade e como era ser homossexual naquela época. Inicialmente, na cidade de São Paulo, o grupo Somos - Grupo de Afirmação Homossexual, apareceu em um debate promovido pela Universidade de São Paulo, no qual os membros puderam estabelecer contato com grupos que também debatiam a homossexualidade. Posteriormente, mulheres lésbicas aproximaram-se desses grupos com a finalidade de ganharem espaço nos debates, ainda que elas fossem minoria.

Com essa crescente luta pela visibilidade lésbica, outras pessoas também foram integrando-se a esses grupos. Inicialmente, eram conhecidos como "simpatizantes", surgindo a sigla GLS, que se referia a Gays, Lésbicas e Simpatizantes. Só em 1990 que foram integradas outras duas letras: "B", que se referia a Bissexuais e "T", que se referia a Transsexuais, sendo a letra "T" a primeira letra a representar gênero, e não orientação sexual, como eram as outras três. Em 2008, na $1^{\text {a }}$ Conferência Nacional GLBT, realizada em Brasília, decidiu-se que a letra "L" deveria abrir a sigla, visando a uma maior representatividade lésbica dentro da comunidade que, por sua vez, ainda era dominada por homens. A mudança transformou a sigla em LGBT. Muitas mudanças foram surgindo em concomitância aos novos estudos e, com elas, outras pessoas foram expressando formas de ser e de sentir diferentes das já existentes, fazendo surgir uma sigla mais completa, visando à inclusão de cada vez mais pessoas: LGBTQIA e mais (+).

Segundo Rita Von Hunty, drag queen criada e performada pelo professor e ator Guilherme Terreri Lima Pereira, no vídeo intitulado Saúde mental, sexualidade, homofobia e suicídio $L G B T Q I A+$, da série É preciso falar, produzida pelo Instituto Vita Alere, o uso do “+”, na sigla, significa que "a comunidade está aberta, porque o gênero e a sexualidade ainda estão abertos. Se a gente entende o gênero humano e a sexualidade humana como não polares, dicotômicos, mas como um espectro difuso e infinito, a gente não pode terminar a sigla onde ela já está.". 
Assim como vemos um movimento que leva em consideração acontecimentos históricos e a inclusão de um maior número de pessoas na comunidade, outra questão importante, nesse sentido, vem sendo discutida: a Língua Portuguesa e a linguagem neutra.

De acordo com o professor titular da UFRJ, da área de Psicanálise, Luciano Elia:

Para a Psicanálise, sobretudo a partir da reelaboração que Lacan empreendeu dos textos freudianos, o sujeito só pode ser concebido a partir do campo da linguagem. Embora Freud não se refira explicitamente a isso, todas as suas elaborações teóricas 16 sobre o inconsciente, nome que delimita o campo primordial da experiência psicanalítica do sujeito, o estruturam como sistema quer de representações (Vorstellungen), de traços de memória (Erinnerzeichen), de signos de percepção (Wahrnehmungszeichen), que se organizam em condensação e deslocamento. Ora, uma teoria como essa exige, metodologicamente, a referência a uma ordem simbólica, a um sistema de articulação de elementos materiais simbólicos, ou seja, à linguagem. (ELIA, 2004, p.36).

Considerando-se a fala de Lacan de que a linguagem constitui o sujeito, é importante perceber que a binaridade de gênero, na Língua Portuguesa, constitui somente sujeitos masculinos ou femininos. Por esse motivo, podemos observar a necessidade das discussões sobre uma linguagem neutra:

A finalidade primordial da linguagem neutra é mostrar a desconstrução de gênero, o rompimento do binarismo nas formas escrita e falada. Uma das línguas oficiais do Brasil - a língua portuguesa (LP) - não possui um "gênero neutro", pois nela nota-se essa "caixinha binária", pois sempre falase o copo, a televisão, ou seja, marca o gênero masculino e o feminino em tudo. Não faz exceção quando refere-se às pessoas. A LP diferencia tudo em masculino e feminino. Com esse avanço da linguagem neutra um novo pronome de tratamento foi criado na língua inglesa, em que suas palavras, em grande parte são consideradas neutras, pois é a partir dos pronomes que se é atribuído um gênero. (LAU, 2017, p. 02).

Por esses motivos, torna-se necessário que docentes estejam sempre integrados a esses assuntos. Acompanhar as questões que envolvem a comunidade LGBTQIA+ e também as mudanças e as flexões da Língua Portuguesa, faz-nos ter entendimento de que a construção das identidades e de suas pluralidades passa por esses lugares e, tendo consciência disso, precisamos buscar, cada vez mais, a integração de pessoas em nossos discursos. 


\subsubsection{Confrontos entre a escola e a comunidade LGBTQIA+ através de relatos de professores de Matemática}

"Em uma das escolas que eu trabalhei recentemente, há cerca de dois anos, a gente recebeu um aluno que vinha em três anos; em um ano era a terceira escola, se eu não me engano, ele 'tava' no último ano do Ensino Médio, já nos meses finais, concluindo o Ensino Médio, com nota de PISM, tentar faculdade, vontade, desejo de fazer Ensino Superior, e tudo mais, e duas escolas que havia passado antes, ele saiu das duas escolas, porque ele tinha sofrido com discursos e com ações de transfobia e de homofobia pesadíssimas. Sempre é pesadíssimo, né? E, assim, inclusive de... - eu não sei se eu podia falar isso, mas posso inclusive dos professores dele dizerem pra ele coisas do tipo assim 'ah, 'cê' vai pro inferno', 'nossa, mas você era uma menina tão linda'. Tratarem ele pelo artigo feminino o tempo inteiro e se recusarem, apesar dele ser um rapaz, se recusarem a ter esse respeito com ele, com a pessoa que ele era. E pra mim foi engraçado, porque eu conheci ele na entrada de uma dessas instituições; e aí ele virou pra mim e falou assim - você é professora aqui? -, eu falei assim - sou -, aí ele falou assim - ah, então, eu 'tô' tentando uma vaga, você sabe se tem vaga pro terceiro ano? Porque eu 'tô' tentando uma vaga, 'tô' querendo 'vim' estudar aqui -. E aí a gente teve aquela conversa de dois minutos. Em outro momento, semanas depois, eu já nem lembrava mais de ter encontrado com ele, a diretora dessa escola me encontrou em um momento que eu tava em reunião com a supervisora e falou assim: - olha, nós temos um assunto muito delicado pra tratar. Eu vou chamar aqui uma pessoa que 'tá' matriculada aqui na escola e 'tá' vindo hoje pelo primeiro dia. Era uma menina, mas agora é um menino. Então, a gente vai ter que saber como lidar com isso. - Aí, 'tô' eu lá sentadinha, com a minha perninha cruzada (risos), entra o rapaz que conversou comigo no portão. E aí eu fiquei pensando assim 'cara, a gente não sabe, a escola não sabe receber'. A escola não sabe. Aí, vem o problema do nome social, aí vem o problema do banheiro, que banheiro que usa, aí vem o problema de a turma não pode saber, e o menino tá 'cagando' pra isso. Pra ele não fazia diferença. Ou fazia, mas não fazia diferença esconder. A gente não sabe lidar.”

Esse relato foi dado pela professora Amanda, em sua entrevista.

A escola possui a vantagem de ser uma das instituições sociais em que é possível o encontro de diferentes presenças. "Ela é, também, um espaço sociocultural marcado por símbolos, rituais, crenças, culturas e valores diversos." SILVA (2015, p.15). Considerando-se que é impossível separar o que acontece dentro da escola com o que ocorre fora dela, 
devemos ou não ter consciência sobre assuntos relacionados à comunidade LGBTQIA+, sendo professores de Matemática? E, caso ocorra uma situação como a que foi relatada pela professora Amanda em nossa sala de aula, como devemos proceder?

A professora Ivani expõe que precisamos ter um preparo ou convidar alguém que tenha esse preparo para conversar com os estudantes em nossas salas de aula: "Abordar por abordar? Entendeu? Então, eu não tenho conhecimento, por exemplo, de transgênero. Eu não tenho conhecimento clínico, físico, emocional. - Ô, gente, 'vão' fazer o seguinte? Eu não tenho conhecimento sobre esse assunto, mas eu exijo que tenha respeito. Vamos parar, e eu vou trazer uma pessoa pra conversar com vocês; eu vou trazer na escola quem puder, quem quiser. 'Vamo' conversar no meio de um médico, de um psicólogo, de um psicopedagogo?’.

Essas experiências fazem-nos perceber que a escola realmente precisa desenvolver mais essas discussões. A forma como cada um lida com essas situações, em sala de aula, pode produzir diferentes modos de pensamento e, consequentemente, de construção de sujeitos.

Não obstante, diante de tudo o que foi abordado nos capítulos anteriores, e para concluir a linha de raciocínio que envolve os temas sociais que decidimos focar nessa pesquisa, podemos estender nossas discussões para um assunto mais amplo: o Bullying.

\subsection{BULLYING}

Segundo Vieira (2009), compreende-se Bullying o ato de:

colocar apelidos, ofender, zoar, gozar, encarnar, sacanear, humilhar, fazer sofrer, discriminar, excluir, isolar, ignorar, intimidar, assediar, aterrorizar, amedrontar, perseguir, tiranizar, dominar, agredir, bater, chutar, empurrar, ferir, roubar e quebrar pertences. (VIEIRA, 2009, p.48-49).

A escola é um espaço plural e, da mesma forma que a diversidade pode ser considerada positiva, podemos abrir margem para a exclusão de quem não a considera importante para a sociedade:

Diferenças, distinções, desigualdades... A escola entende disso. Na verdade, a escola produz isso. Desde seus inícios, a instituição escolar exerceu uma ação distintiva. Ela se incumbiu de separar os sujeitos - tornando aqueles que nela entravam distintos dos outros, os que a ela não tinham acesso. Ela dividiu também, internamente, os que lá estavam, através de múltiplos mecanismos de classificação, ordenamento, hierarquização. A escola que nos foi legada pela sociedade ocidental moderna começou por separar adultos de 
crianças, católicos de protestantes. Ela também se fez diferente para os ricos e para os pobres e ela imediatamente separou os meninos das meninas. (LOURO, 1997, p.57).

Identificar o que norteia uma situação de Bullying é essencial. Nesse sentido, considero que um dos problemas principais dos gestores e dos professores é a ausência de debates sobre assuntos que podem ser incentivadores para atitudes de opressão.

Observa-se que os pesquisadores, de forma geral, ao dissertarem sobre as supostas "causas" do que chamam bullying, dentre as quais se destacam os fatores econômicos, sociais, culturais e particulares, não as problematizam. Tal atitude desemboca na defesa da expressão genérica do "educar para a paz" utilizada por Fante (2005). Desta forma, as influências familiares, de colegas, da escola e da comunidade, as relações de desigualdade e de poder, a relação negativa com os pais e o clima emocional frio em casa parecem considerados naturais e apartados das contradições sociais que os produziram. (ANTUNES; ZUIN, 2008, p. 36).

De maneira geral, é importante entender o motivo que coloca as áreas de Exatas como áreas que não induzem um pensamento crítico. Por isso, vamos entender melhor o que dizem os parâmetros curriculares sobre qual o papel da Matemática e dos professores que a lecionam nas escolas.

\subsection{O INCENTIVO À CULTURA NAS ESCOLAS E A HIERARQUIZAÇÃO DA MATEMÁTICA}

Segundo a BNCC (Base Nacional Comum Curricular), na competência número três, abordar a cultura nas escolas deve ser incentivada com a finalidade de:

Valorizar e fruir as diversas manifestações artísticas e culturais, das locais às mundiais, e também participar de práticas diversificadas da produção artístico-cultural. (BNCC, 2017, p.9).

Contudo, a própria BNCC diz que as áreas que mais contribuem para esse aprendizado são as áreas de Humanas e de Linguagens. Se a própria base não valoriza que profissionais da área de Exatas tratem assuntos sociais em suas aulas, como essa área ganha espaço no ambiente escolar para falar desses temas? Quando tiramos as vertentes culturais e artísticas de cena, a Matemática ganha uma outra posição no ambiente escolar. "As demais ciências que me perdoem, mas a Matemática é sua soberana. Rainha e, ao mesmo tempo, 
prestativa servidora de todas as outras, a quem generosamente socorre com clareza e eficácia”. (GARBE, 2018, p.28).

Durante grande parte da minha trajetória escolar, e até mesmo da minha vida universitária, escutei esse argumento exposto pelo professor Gilberto Garbe. Pessoas com uma predileção para a Matemática sempre foram consideradas inteligentes. Inclusive, algumas pesquisas realizadas na Inglaterra dizem que o gênero também está relacionado a um bom desempenho matemático.

Os meninos apresentavam melhor resultado no aprendizado da matemática do que as meninas, quando ambos estavam na mesma sala de aula. Ao separá-los, porém, as alunas obtiveram notas mais elevadas. Isto prova, de acordo com a cientista política da UFRGS, que os professores investiam mais nos garotos por imaginar que o interesse deles por matemática seria maior do que o das garotas (PINTO, 1999, p. 17).

Querendo saber o que os professores entrevistados pensam sobre o que disse Garbe; Pinto (1999) e, percebendo que, até hoje, existe uma posição hierárquica que algumas disciplinas ocupam na grade curricular e nos vestibulares, levantei a seguinte questão: Por que a Matemática é considerada mais importante do que Artes, por exemplo?

Em meu diálogo com a professora Ivani acerca desse assunto, ela diz que: "a Matemática não é mais importante. Desconsidero isso, até porque, eu gostava muito mais de esporte, de ficar dentro da quadra, do que ficar dentro da sala de aula".

Eu insisti, dizendo: "mas, acho que, socialmente, a gente vê que se dá muito mais importância para Matemática e Português, e menos importância para as outras áreas.” E ela concordou, afirmando: "sim, porque são as profissões que eles consideravam - isso é época, né, isso é cíclico. Tanto que antigamente as mulheres bordavam, faziam... Então, assim, isso é cíclico, né? A gente pode ir mudando isso aos poucos.”.

Continuando, ela afirma: "hoje, eu vejo a briga do pessoal de Literatura, de não sei o quê, querendo mais horários nas aulas e tudo. Por quê? Porque a Redação se tornou uma coisa importante no ENEM.". E, para encerrar, a professora considera que "[...] daqui a pouco, a Matemática não é tão importante, acho até que deveria diminuir muito essa quantidade de forma aleatória que vem sendo dada. Mas, é um assunto que, profissionalmente, as pessoas mais inteligentes são as que sabem Matemática. Se a cultura ainda é essa, né? A fama ainda é essa, os pais ainda exigem isso.”. 
Para encerrar seu pensamento, Ivani diz que "não são só os professores que querem dar. Os pais ainda exigem, os filhos ainda querem porque querem ser mais bem sucedidos. Né? Então, assim, a pessoa que faz Artes, tirando alguns mega talentos internacionais, né, não são ricas. Então, você vai querer que seu filho aprenda uma coisa que ele não vai ter dinheiro?".

A fala da professora Ivani pode ser complementada pela fala do professor Marcelo, que diz o seguinte: "se você for pensar no âmbito artístico, constantemente não é uma profissão de futuro, porque não é valorizada, não tem valor. Não se vive de arte, principalmente, aqui, no Brasil. Tem até um colega, um amigo da minha mãe, que ele pintava aqui no Brasil - porque ele tinha inspiração aqui no Brasil - mas, ele ia lá pra Austrália pra poder vender as obras dele. Então, assim, não sei muito sobre o contexto fora daqui, mas, aqui, não se vive, assim. Meu marido é tatuador e é complicado. É bem complicado. Você viver da arte é bem complicado. E é muito triste, porque tem tanto potencial. A gente vê, em várias áreas, pessoas que abriram mão daquele potencial, daquela vocação, pra viver uma outra realidade que pode ser opressora; pode não ser o lugar que a pessoa quer e, talvez, ela nem produza tanto. Talvez, ela não consiga produzir tanto, porque não é aquilo que traz paixão, sabe? Não é aquilo que dá 'tesão'. Então, é complicado. E, sim, nas escolas, também, a questão cultural, ela é muito pouco abordada, sabe? Ela é muito pouco abordada. E uma riqueza cultura é fundamental, sabe? Eu vejo, assim - porque eu, também, dei uma 'roletada' aí, no Brasil. Morei no Sul, morei, também, no Nordeste, e vim morar aqui, também -. e é interessante, porque é assim que você consegue abarcar a realidade. São bolhas, né? A gente vive em bolhas sociais que a gente só sabe daquela realidade. As pessoas não têm consciência disso e não conseguem sair dessas bolhas. Então, é fundamental a gente quebrar, começar a quebrar essas bolhas, e ter mais noção da realidade. E, isso, a cultura é fundamental pra isso. Traz críticas políticas, traz potencial de resistência. Sem a cultura, acho que a gente nem sobreviveria resistindo sem as músicas, sem a arte, no geral. E ela é muito plural e muito rica. Aqui, no Brasil, caramba! Tenho conhecido cantores e atores e pessoas que eu não conhecia antes, porque não eram pauta da escola e poxa! Tanta coisa rica, aí, que a gente pode trazer pras crianças, pros adolescentes. E é isso.”.

\section{O DOCUMENTÁRIO}


Ao entrar no mestrado em Educação Matemática, os alunos são informados sobre a necessidade de se produzir um produto educacional. Esse produto, por sua vez, deve ser útil e aplicável em sala de aula para complementar todo o trabalho feito nas dissertações dos mestrandos do programa. Pesquisando e analisando os anos anteriores, a fim de inspirar-me sobre o que poderia ser feito, percebi que, assim como o tema abordado é considerado raro, poderíamos criar um material, igualmente inesperado, para auxiliar para auxiliar a formação de professores.

Apenas uma aluna, dentro do perceptível por mim, fez um documentário audiovisual, no programa de mestrado de que participo. E, diante da escassez desse tipo de ferramenta, surgiu-me a vontade de usá-la como um fundamental suporte para o meu trabalho.

Diante desse desafio, apareceu, também, uma imensa insegurança. Eu, professor de Matemática, que possuía noções básicas de edição para postar videoaulas em meus canais profissionais, deparei-me com um amplo estudo acerca de recursos de iluminação, câmeras para gravação, programas de edição de vídeo, microfone para captação de voz e todos os detalhes exigidos para a produção desse tipo de conteúdo. Como se não bastasse, além de todo aparato técnico, precisei pesquisar grupos de atores residentes na cidade de Juiz de Fora e convidá-los para fazer parte de um projeto educacional, sem remuneração ou qualquer finalidade lucrativa.

Inesperadamente, um amigo, que também é ator, indicou-me o nome de três pessoas: Andreza Dias, Michel Costa e Saulo Machado. Ambos já se conheciam e fizeram parte de um dos grupos mais conhecidos da cidade, o Grupo Divulgação, que possui sede na casa de cultura da Universidade Federal de Juiz de Fora, mas não possui vínculo direto com a instituição. Quando convidei e expliquei, para esses atores, qual era o teor do projeto e as ideias somente por mim visualizadas até o momento, e, sem saber muito se realmente ficaria como esperado, fui amparado de forma imediata pela aceitação desse convite que, ao meu ver, era como "mergulhar no desconhecido". Inclusive, gostaria de aproveitar para agradecê-los pelo excepcional trabalho realizado no papel dos professores e por terem apostado em mim. Meses depois, uma outra atriz compôs o time de professores do documentário: Fernanda Sevarolli, realizando um excepcional trabalho. Gostaria de agradecer, também, aos atores que fizeram os papéis dos alunos. São eles: Felipe Ribeiro, Gabriela Mara, Rodrigo Luiz, João Pedro Vieira, Mariana Machado, Ítalo Pontes, Gabriela Mara, Lizandra Dantas, Luan Pedretti, Filipe Krepe e Rodrigo Luiz. 
Com a parte técnica e artística pronta, decidi arriscar um pouco mais. Entrei em contato com cantores que sempre me inspiraram com suas músicas e que são referência de luta e de resistência em nosso país e pedi, de forma humilde, e já sabendo o quão difícil seria, algumas de suas canções para compor o documentário. Para minha surpresa, dois grandes nomes da música popular brasileira aceitaram minha proposta: Criolo e Elza Soares. Uma mistura de felicidade e de responsabilidade tomou conta do meu dia a dia e, quanto mais eu evoluía na criação desse produto, mais gratidão por tudo ter corrido de forma tão natural eu sentia. Além disso, alguns artistas em ascensão, como o cantor WD, o rapper João Gama e a cantora MC Xuxu, também cederam suas composições para o documentário.

\subsection{DESAFIOS DURANTE O ISOLAMENTO SOCIAL}

O processo de gravação do documentário começou sem o cenário de isolamento social, visto que a pandemia de Coronavírus ainda não havia tomado as graves proporções que são vistas atualmente. Pouco se ouvia falar sobre o assunto, no Brasil. De forma abrupta, o vírus chegou a nosso país, mudando completamente nossa forma de viver e se relacionar. As aulas foram suspensas, e novos acessórios puderam ser vistos nas ruas, como as máscaras e o álcool em gel. Perante essa nova realidade, tivemos que nos adaptar. Cessamos as gravações por, aproximadamente, seis meses, enquanto estudávamos novas formas de continuá-las com segurança para todos os envolvidos. Além disso, tivemos que adaptar o roteiro inicial por não possuir mais salas de aula e escolas para gravar, a fim de evitar aglomerações. Inicialmente, focaríamos nas histórias dos professores e abriríamos o discurso de acordo com os acontecimentos dentro do espaço escolar. Com a pandemia, decidimos focar mais nas histórias de alguns alunos e associá-las aos depoimentos dos professores coletados nas entrevistas.

Optando somente pelas pessoas realmente necessárias no local de gravação, e tomando todos os cuidados possíveis, retomamos as gravações. Após muita discussão, chegamos à conclusão da necessidade de inserir o isolamento social e os problemas educacionais que os professores enfrentaram durante esse tempo, no documentário final.

\subsection{DIREITOS AUTORAIS}


Os direitos do uso de imagem dos atores e dos fonogramas cedidos pelos cantores estão devidamente anexados, respeitando-se todas as leis que a produção audiovisual exige.

\section{CONSIDERAÇÕES FINAIS}

Muitos podem ter começado essa dissertação em busca de uma resposta para a pergunta inicial: como lidar com a diversidade dentro da sala de aula? No decorrer deste trabalho, considero que ficou claro, para os leitores, que não existe uma forma correta, mas um ponto é essencial: o diálogo. Paulo Freire (1970) fala sobre a essencialidade de dialogar:

É através deste que se opera a superação de que resulta um termo novo: não mais educador do educando do educador, mas educador-educando com educando-educador. Desta maneira, o educador já não é o que apenas educa, mas o que, enquanto educa, é educado, em diálogo com o educando que, ao ser educado, também educa. Ambos, assim, se tornam sujeitos do processo em que crescem juntos [...]. (FREIRE, 1970, p. 80).

No processo de escrita da dissertação, tive contato com temas que, anteriormente, não conhecia de forma aprofundada. Temas que englobam questões raciais e termos que aparecem quando tratamos desse assunto são um exemplo. Afinal, como dialogar com professores, quando não sabemos como levantar, de forma coerente e com um bom embasamento teórico, os debates a serem propostos por esta dissertação?

Por esse motivo, além das questões LGBTQIA+, as quais eu domino devido ao fato de estudar e de vivenciar, há mais tempo, as problemáticas que envolvem essa comunidade, aprendi, também, sobre o outro. Como disse a professora Amanda, em sua entrevista, "é muito difícil entender a dor do outro, pois, ela não toca na gente". E eu, de uma forma muito sutil, respeitosa e subjetiva, consegui adentrar, através do lugar que ocupo na sociedade - que é de homem e branco - em discussões sob a minha perspectiva, sem deixar de fundamentar-me em pesquisadores e em escritores que passam e sentem os assuntos referentes a essas discussões.

Baseado nisso, mais do que um primeiro contato com temas sociais que normalmente não são abordados por pessoas que lecionam Matemática, a proposta principal dessa dissertação foi incentivar conversas a fim de que se possa entender a construção de mundo dos nossos colegas de trabalho, sejam eles da mesma área ou de áreas diferentes, bem como entender as vivências dos estudantes. Todos compõem o espaço escolar e todos colaboram para que a diversidade aconteça. Afinal, como disse, novamente, a professora 
Amanda, em sua entrevista, "a escola é um recorte da sociedade", e não podemos colocá-la como um espaço inatingível.

Para o produto educacional, também passei por novas experiências, desde o manuseio de um celular para gravar as cenas, até a escrita de roteiros, gerenciamento de atores e edição de vídeos. Não possuía noção sobre quase nada para a criação do documentário e, por isso, pude ampliar meus conhecimentos na área audiovisual, ao passar por esse processo.

Com esse documentário, esperamos que os debates cheguem a mais pessoas, principalmente aos docentes das áreas de Exatas e seus estudantes. Sabemos que as ferramentas tecnológicas colaboram para que mais espaços sejam alcançados e sabemos, também, que o mundo audiovisual pode passar sensações e sentimentos que vão além da leitura dessa dissertação. Por esse motivo, produzimos, durante quase dois anos, uma obra intitulada "XÆ" e, como o próprio nome diz, buscamos retratar histórias que surgem nas escolas de forma recorrente e que são confrontadas diariamente por grande parte dos professores de Matemática. Expomos, então, corpos e sujeitos que, de certa forma, não se sentem pertencentes aos padrões sociais normativos impostos, além de retratarmos a realidade pessoal de professores ao deixarem os muros das escolas, mostrando que o simples fato de dominar uma disciplina não nos prepara para enfrentarmos muitas realidades. Em consequência, estamos propondo, ainda, uma possível formação de professores nos temas por mim abordados, utilizando, como ponto de partida, este trabalho. 


\section{REFERÊNCIAS}

ANTUNES, Deborah Christina; ZUIN, Antônio Álvaro Soares. Do Bullying ao preconceito: os desafios da barbárie à educação. Revista Psicologia \& Sociedade, n. 20, v. 1, p. 33-42, 2008.

APOLINÁRIO, Eleonora Beatriz Ramina; MANFREDINI, Giulia Aniceski; GRALAK, Mariana Mehl; MINATOGAWA, Mayume Christine; PERRONI, Thais Cattani. As representações do movimento de Stonewall nos Estados Unidos. Epígrafe, São Paulo, v.7, n.7, p. 97-108, 2019.

BOSCOLO, Dulcineia. O desenvolvimento profissional do professor: o conceito geográfico de lugar. São Paulo, 2018. Disponível em: $<$ https://sucupira.capes.gov.br/sucupira/public/consultas/coleta/trabalhoConclusao/viewTrabal hoConclusao.jsf?popup=true\&id_trabalho=6461753>. Acesso em: 02 out. 2019.

BOTTOMORE, Tom. Dicionário do pensamento Marxista. Rio de Janeiro, Zahar, 2012, p.423.

BOURDIEU, Pierre. Les trois états du capital culturel. Actes de la recherche en sciences sociales. Paris, n. 30, p.2, 1979.

BOURDIEU, Pierre. Sociologia. São Paulo: Ática, p. 75, 1983.

Censo Escolar 2017 - Notas Estatísticas. Brasília, 2018. Disponível em: $<$ https://drive.google.com/file/d/1diB1miZTKvuVByb9oXIXJgWbIW3xLL_f/view>. Acesso em 08 set. 2020.

DE OLIVEIRA, Cristiane Costa Bicunha. Ditadura no Brasil: da Violência a Coerção Social. Lins: Faculdade Auxilium de Filosofia, Ciências e Letras, 2003.

DONÁRIO, A; SANTOS, R. B. Reflexões em economia. Conceitos fundamentais. Centro de Análise Económica de Regulação Social (CARS), Universidade Autónoma de Lisboa, p.34, 2016. 
ELIA, Luciano. O conceito de sujeito. Psicanálise passo a passo. Rio de Janeiro: Jorge Zahar, 50 ed. 2004.

Estudos e Pesquisas - Informação demográfica e socioeconômica - nº̛1, 2019.

FREIRE, Paulo. Pedagogy of the Oppressed. New York: Herder \& Herder, 1970.

GARBI, Gilberto. Revista do professor de Matemática. № 96, p.28, 2018.

GLASERSFELD, Von E. Learning as a constructive activity. In J. Bergeron \& $\mathrm{N}$. Herscovics (Eds.), Proceedings of the Fifth PME-NA, Montreal, 1993.

GODOY, Elenilton V. Revista de Administração de Empresas / EAESP / FGV, São Paulo, p. $21-29,1995$.

GODOY, Elenilton V; MUSHA, Fernanda D.; LIMA, Yasmin C.; SILVA, Marcio A.. Ensino em Revista. Uberlândia, MG, v.27, n.3, p.979-1004.

JOHNSON, Maisha. O Que Privilégio Significa (E O Que Não Significa). Disponível em $<$ https://edisciplinas.usp.br/pluginfile.php/4118463/mod_resource/content/1/O\%20que\%20pri vile $\%$ CC $\% 81$ gio $\% 20$ significa $\% 20 \% 28 \mathrm{e} \% 20$ o $\% 20$ que $\% 20$ na $\%$ CC $\% 83$ o $\% 20$ significa $\% 29 \% 2$ 0_\%20Na\%CC\%830\%20Me\%20Kahlo.pdf>. Acesso em 06 ago. 2020.

LAU, Héliton D. O uso da linguagem neutra como visibilidade e inclusão para pessoas trans não-binárias na Língua Portuguesa: A voz “del@s” ou “delxs"? Não! A vos “delus”, Paraná, p.2, 2017.

LOURO, Guacira Lopes. Gênero, Sexualidade e Educação: uma perspectiva pósestruturalista. 6 ${ }^{\text {a }}$ Edição, Petrópolis: Editora Vozes, 2003.

LOURO, Guacira Lopes. Gênero, sexualidade e educação: uma perspectiva pósestruturalista. Petrópolis: Editora Vozes, p. 57, 1997. 
NORONHA, Daisy Pires; FERREIRA, Sueli Mara S. P. Revisões de literatura. In: CAMPELLO, Bernadete Santos; CONDÓN, Beatriz Valadares; KREMER, Jeannette Marguerite (orgs.). Fontes de informação para pesquisadores e profissionais. Belo Horizonte: UFMG, 2000.

PINTO, Céli R. Meninos no pátio; meninas na aula. Extra Classe, Porto Alegre, p. 17, 1999.

PONTE, João Pedro da. Concepções dos professores de Matemática e Processos de Formação. In: Educação Matemática: Temas de Investigação. Instituto de Inovação Educacional, Lisboa, p. 8-9,1992.

Disponível em: <http://www.educ.fc.ul.pt/docentes/jponte/artigos_pt.htm>. Acesso em: 10 fev. 2021.

REIS, Janete. Relação família-escola: a experiência de uma escola pública da periferia de Salvador - BA. Dissertação da Universidade Católica do Salvador. Superintendência de Pesquisa e Pós-Graduação. Mestrado em Família na Sociedade Contemporânea. Salvador, p.9, 2013.

Revista de Estudos Aplicados em Educação (REAe), v. 2, n. 3. jan./jun. 2017.

RIBEIRO, Djamila. Feminismos Plurais - Lugar de Fala. São Paulo, p. 77, 2019.

RIBEIRO, Djamila. Pequeno manual antirracista. $1^{a}$ ed. São Paulo: Companhia das Letras, 2019.

SANTHIAGO, Ricardo; MAGAlHÃES, Valéria Barbosa de. História Oral na Sala de Aula. Autêntica, p.25, 2015.

SBEM. GT13. Diferença, Inclusão e Educação Matemática. 2013. Disponível em: $<$ http://www.sbembrasil.org.br/sbembrasil/index.php/grupo-de-trabalho/gt/gt-13>. Acesso em: 03 de out. 2019. 
SILVA, Tomaz. A produção social da identidade e da diferença. Disponível em: $<$ http://www.diversidadeducainfantil.org.br/PDF/A\%20produ\%C3\%A7\%C3\%A3o\%20social $\% 20 \mathrm{da} \% 20$ identidade $\% 20 \mathrm{e} \% 20 \mathrm{da} \% 20$ diferen $\% \mathrm{C3} \% \mathrm{~A} 7 \mathrm{a} \% 20 \% 20$ Tomaz $\% 20$ Tadeu $\% 20 \mathrm{da} \%$ 20Silva.pdf>. Acesso em: 03 de out. 2019.

SILVA, Tomaz. Identidade e diferença: as perspectivas dos estudos culturais. Petrópolis: Vozes, p.74, 2003.

SILVA, Vanja M. B. A diversidade em sala de sula: um desafio sempre atual. Buritis, MG, p. 15, 2015.

ALMEIDA, Silvio. FEMINISMOS PLURAIS - RACISMO ESTRUTURAL. São Paulo, p. 50, 2019.

THOMAS JR., R.R. Beyond race and gender: unleashing the power of your total work force by managing diversity. New York: AMACOM, 1991.

VIANNA, Claudia P. O Sexo e o Gênero da Docência. Cadernos Pagu (17/18), p.81-103, $2001 / 2002$.

VIEIRA, Rafael Rodrigues. Bullying: estudo de caso em escola particular. Dissertação de Mestrado - Universidade de Brasília, Instituto de Psicologia, Programa de Pós-Graduação em Psicologia Social, do Trabalho e das organizações, 2009.

GREEN, James N.; QUINALHA, Renan; CAETANO, Márcio; FERNANDES, Marisa. História do Movimento LGBT no Brasil. $1^{\text {a }}$ Edição, 2018, São Paulo, p. 10.

HUNTY, Rita V; PEREIRA, Guilherme T. L. Programa É Preciso Falar \#7 - Vita Alere. Disponível em: $<$ https://www.youtube.com/watch?v=81zxnxTmFbY\&t=146s\&ab_channel=VitaAlerePreven \%C3\%A7\%C3\%A3oePosven\%C3\%A7\%C3\%A3odoSuic\%C3\%ADdio $>$. Acesso em: 26 jan. 2021. 
KRENAK, Ailton. Ideias Para Adiar O Fim Do Mundo. $1^{\text {a }}$ Edição, São Paulo, Companhia de Letras, p. 33, 2019.

BNCC. Base Nacional Comum Curricular, p.9, 2017. Disponível em: $<$ http://basenacionalcomum.mec.gov.br/>. Acesso em: 15 fev. 2021. 
APÊNDICE A - Pesquisas da CAPES relacionadas aos temas apresentados

\begin{tabular}{|c|c|c|c|c|}
\hline Título & Autor & Ano & Tipo & Pesquisa \\
\hline $\begin{array}{c}\text { Uma investigação } \\
\text { junto a uma } \\
\text { formação política } \\
\text { de um docente de } \\
\text { Matemática }\end{array}$ & $\begin{array}{l}\text { Diego Marques } \\
\text { Mesquita }\end{array}$ & 2018 & Dissertação & 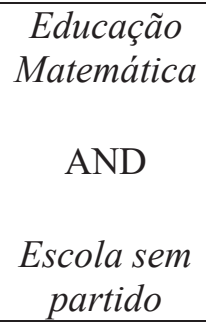 \\
\hline $\begin{array}{c}\text { Escola e relações } \\
\text { étnico-raciais: } \\
\text { uma análise das } \\
\text { enunciações de } \\
\text { alunos de uma } \\
\text { instituição pública } \\
\text { de Estrela-RS }\end{array}$ & Mônica Nunes & 2017 & Dissertação & $\begin{array}{c}\text { Educação } \\
\text { Matemática } \\
\text { AND } \\
\text { Racismo }\end{array}$ \\
\hline $\begin{array}{c}\text { Os discursos de } \\
\text { gênero e } \\
\text { diversidade sexual } \\
\text { nas escolas } \\
\text { estaduais da } \\
\text { região de Mogi das } \\
\text { Cruzes } \\
\end{array}$ & $\begin{array}{l}\text { Márcia Cunha } \\
\text { dos Santos }\end{array}$ & 2014 & Dissertação & $\begin{array}{c}\text { Matemática } \\
\text { AND } \\
\text { Homofobia }\end{array}$ \\
\hline $\begin{array}{c}\text { Gênero, } \\
\text { sexualidade e } \\
\text { educação: } \\
\text { histórias de } \\
\text { homossexuais e } \\
\text { seus discursos } \\
\text { sobre os } \\
\text { movimentos sociais }\end{array}$ & $\begin{array}{l}\text { Carla Adriana } \\
\text { Menegotto }\end{array}$ & 2015 & Dissertação & $\begin{array}{c}\text { Matemática } \\
\text { AND } \\
\text { Homofobia }\end{array}$ \\
\hline $\begin{array}{c}\text { Diversidade } \\
\text { Sexual, Escola e } \\
\text { Família: } \\
\text { contribuições para } \\
\text { as práticas de } \\
\text { ensino }\end{array}$ & $\begin{array}{c}\text { Roberta Ribeiro } \\
\text { Cicco }\end{array}$ & 2017 & Tese & $\begin{array}{c}\text { Matemática } \\
\text { AND } \\
\text { Homofobia }\end{array}$ \\
\hline $\begin{array}{c}\text { Percepções } \\
\text { docentes sobre } \\
\text { sexualidade } \\
\text { humana na } \\
\text { perspectiva do } \\
\text { letramento } \\
\text { científico nos anos } \\
\text { iniciais do ensino } \\
\text { fundamental }\end{array}$ & $\begin{array}{c}\text { Adriano Santos } \\
\text { de Mesquita }\end{array}$ & 2018 & Dissertação & $\begin{array}{c}\text { Educação } \\
\text { Matemática } \\
\text { AND } \\
\text { Sexualidade }\end{array}$ \\
\hline $\begin{array}{l}\text { Sexualidade na } \\
\text { escola: } \\
\text { encaminhamentos }\end{array}$ & $\begin{array}{c}\text { Josiane da Silva } \\
\text { Quirino } \\
\text { Rodrigues }\end{array}$ & 2013 & Dissertação & $\begin{array}{c}\text { Educação } \\
\text { Matemática }\end{array}$ \\
\hline
\end{tabular}




\begin{tabular}{|c|c|c|c|c|}
\hline $\begin{array}{c}\text { metodológicos na } \\
\text { perspectiva dos } \\
\text { professores de } \\
\text { Ciências }\end{array}$ & & & & $\begin{array}{c}\text { AND } \\
\text { Sexualidade }\end{array}$ \\
\hline $\begin{array}{l}\text { Quem calculava? } \\
\text { Representações de } \\
\text { gênero na relação } \\
\text { mulher matemática } \\
\text { na obra o homem } \\
\text { que calculava de } \\
\text { Malba Tahan }\end{array}$ & $\begin{array}{l}\text { Luíza Gabriela } \\
\text { Razera de Souza }\end{array}$ & 2013 & Dissertação & $\begin{array}{c}\text { Educação } \\
\text { Matemática } \\
\text { AND } \\
\text { Sexualidade }\end{array}$ \\
\hline $\begin{array}{c}\text { Using Supervised } \\
\text { Machine Learning } \\
\text { and Sentiment } \\
\text { Analysis } \\
\text { Techniques to } \\
\text { Predict } \\
\text { Homophobia in } \\
\text { Portuguese Tweets }\end{array}$ & $\begin{array}{c}\text { Vinícius Gomes } \\
\text { Pereira }\end{array}$ & 2018 & Dissertação & $\begin{array}{c}\text { Matemática } \\
\text { AND } \\
L G B T\end{array}$ \\
\hline $\begin{array}{l}\text { Diversidade Sexual } \\
\text { e Ensino de } \\
\text { Ciências: } \\
\text { Buscando Sentidos }\end{array}$ & $\begin{array}{c}\text { Leandro Jorge } \\
\text { Coelho }\end{array}$ & 2014 & Dissertação & $\begin{array}{c}\text { Matemática } \\
\text { AND } \\
\text { LGBT }\end{array}$ \\
\hline $\begin{array}{l}\text { Professoras trans } \\
\text { brasileiras: } \\
\text { ressignificações de } \\
\text { gênero e de } \\
\text { sexualidades no } \\
\text { contexto escolar }\end{array}$ & $\begin{array}{l}\text { Neil Franco } \\
\text { Pereira de } \\
\text { Almeida }\end{array}$ & 2014 & Tese & $\begin{array}{c}\text { Matemática } \\
\text { AND } \\
L G B T\end{array}$ \\
\hline $\begin{array}{c}\text { Sexualidade, } \\
\text { Evolução e } \\
\text { Educação: o } \\
\text { conceito } \\
\text { darwinista da } \\
\text { seleção sexual e } \\
\text { suas implicações } \\
\text { para o ensino de } \\
\text { ciências }\end{array}$ & Gustavo Piovezan & 2014 & Tese & $\begin{array}{c}\text { Matemática } \\
\text { AND } \\
L G B T\end{array}$ \\
\hline $\begin{array}{l}\text { Das ruas para a } \\
\text { escola: } \\
\text { considerações } \\
\text { sobre a inclusão } \\
\text { social de sujeitos } \\
\text { trans na educação } \\
\text { de jovens e adultos }\end{array}$ & $\begin{array}{c}\text { Guilherme } \\
\text { Augusto Maciel } \\
\text { Ribeiro }\end{array}$ & 2017 & Dissertação & $\begin{array}{c}\text { Matemática } \\
\text { AND } \\
L G B T\end{array}$ \\
\hline $\begin{array}{c}\text { Gênero e } \\
\text { sexualidade na } \\
\text { escola: da } \\
\text { educação legal à } \\
\text { educação real }\end{array}$ & Ana Paula Brasil & 2017 & Dissertação & $\begin{array}{c}\text { Matemática } \\
\text { AND } \\
\text { LGBT }\end{array}$ \\
\hline
\end{tabular}




\section{ANEXO A - Entrevistas Transcritas}

\section{ENTREVISTA 1}

Entrevistador: Mas vai ser mais uma conversa. Aí, uma outra coisa: tem um termo de sigilo, que eu não trouxe...

Amanda: não, mas eu sei...

Entrevistador: Mas, a gente se encontra sempre, assim, qualquer coisa eu te entrego aqui no colégio.

Como vai funcionar: ninguém vai saber que você foi uma das entrevistadas, como um respaldo, até, de preservar sua identidade como pessoa, como professora, porque, às vezes, "cê" vai dar opiniões que nem todo mundo do colégio concorda, e... né?

Amanda: Uhum.

Entrevistador: E... tem esse termo de sigilo falando exatamente isso que eu te falei aqui, agora, tá?

Aí, Amanda, a primeira pergunta é: quando você escuta falar sobre gênero e sexualidade, o que que você pensa?

Amanda: Então, olha só: pra mim, são coisas novas, por quê? Até um grande momento da minha vida, e até um passado recente, eu nunca tinha ouvido falar. E se alguém já tinha falado perto de mim, eu nem dei bola. Não parecia nada assim... até importante, ou eu nem tinha lembrança de já ter ouvido. Até o momento em que eu, de fato, eu não ouvi de passagem, mas eu ouvi falar a respeito de gênero e sexualidade, e, aí, eu ouvi falar que isso constitui a todos nós, a quem somos.

Entrevistador: Sim.

Amanda: Então, eu entendi assim: é um negócio muito importante, porque ele constitui a cada um de nós, né? A maneira como somos em relação a todas as relações que a gente estabelece, ou a gente escolhe deixar de estabelecer, ou é impedido de estabelecer durante a vida, como a gente se posiciona, hábitos, comportamentos, escolhas, tudo "tá" relacionado a isso. Eu... é... sou um pouco tímida pra poder falar formalmente a respeito de gênero e sexualidade, porque eu acho que falta em mim conhecimento.

Entrevistador: Entendi. 
Amanda: E especialmente como educadora, eu acho que a gente sempre tem que ser muito cuidadoso quando a gente vai abordar um assunto, abrir um debate, se posicionar, da maneira que for, seja a posição que a gente for tomar; a gente tem que ser cuidadoso, a gente tem que saber sobre o que a gente "tá" falando, não pode ser o que a gente só ouviu falar. Então, assim... é... eu sou tímida... No entanto, há em mim uma coisa que grita pela importância. Então, eu procuro me informar, eu procuro ter contato, eu procuro estudar.

Entrevistador: Tá. Agora...

Amanda: Respondi?

Entrevistador: Respondeu super bem!

Amanda: O gravador deixa a gente um pouco nervoso, né? (risos). Não, mentira!

Entrevistador: Você tá... (interrupção/corte da fala pela entrevistada).

Amanda: Só um pouquinho.

Entrevistador: É? Mas a gente vai se soltando.

Amanda: É que a gente quer falar bonito! (risos).

Entrevistador: Não, mas você já fala bonito, Amanda! (risos).

É... e na escola, Amanda... assim, qual é a importância desse tema dentro da escola? E se você já presenciou, em algum momento, alguma situação que você precisou de entrar nesse assunto.

Amanda: O tempo inteiro. Por quê? Até o dia que a gente tava conversando, eu falei a respeito disso. Eu já tive muito essa visão, eu acho que ela ainda é majoritária em vários setores da sociedade, em vários níveis, de que a escola é um "sacro-lugar”; separado, santificado, protegido, e não é assim. Eu, hoje, enxergo a escola, já há algum tempo, como um recorte da sociedade. Ela é um dos espaços da sociedade. Então, é... do mesmo jeito que nós somos constituídos por um batalhão de coisas e as questões relacionadas a gênero e sexualidade são uma das coisas dentro desse batalhão, seja fora da escola, seja em outros espaços institucionais como a escola e na escola, também. Então, assim, o tempo inteiro a gente se depara com situações que é... eu acho que na sociedade, no ponto que a gente "tá" agora, como humanidade mesmo, gritam por atenção, a como que identidade de gênero se constitui e se move socialmente; a como que sexualidades se constituem e se movem, e "tão" o tempo inteiro - nos constituem e se solidificam - mas "tão" o tempo todo se reorganizando e 
se tornando outros modos, também. Então, assim, muito. É... factual. Indo em fatos... é... eu já me deparei, assim, não vou citar nada, tá? Nada.

Entrevistador: Uhum, sim.

Amanda: É o tempo inteiro, o dia inteiro; é o tempo inteiro como é dentro da escola, como é fora. Mas, eu já me deparei com turmas... é... extremamente... a primeiro momento, assim, turmas, por exemplo, de Ensino Fundamental, "tô" me lembrando de uma turma especial. Em primeiro momento, você... a minha análise foi assim: "Nossa! Tem uma agressividade - no sentido negativo, quando a gente usa a palavra agressividade - em relação a gênero e sexualidade acontecendo nessa turma o tempo inteiro". É um bombardeando o outro o tempo inteiro com piadinha, isso que a gente chama de piadinha, com... é... contato físico inapropriado, com... é... agressões menos veladas e com... um... talvez, eu possa chamar de desconhecimento mesmo. E aí, em segundo momento, quando eu parei pra pensar a respeito disso, eu falei assim, “não, essa turma, ela 'tá' gritando por saber o que que é isso tudo que 'tá' acontecendo em relação a gênero e em relação à sexualidade. Uma turma de ensino fundamental, numa idade aí que a gente categoriza como início da adolescência. Então, que a gente já se comporta em relação a eles - todos nós, crianças e adultos - nos comportamos em relação a pessoas que estão nessa fase de determinados modos bem encaixotadinhos, tem que tratar o adolescente assim, e o adolescente, ele se comporta assado. Então, assim, sendo bombardeados por isso o tempo inteiro. E, assim, solicitando que houvesse um cuidado com isso. Por ser dentro da escola, que houvesse um cuidado escolar com isso. Se fosse na família, com certeza acontece lá também, um cuidado familiar com isso; se fosse em outro espaço, cuidados que competem a cada uma dessas... desses lugares e desses grupos que lá estão. Então, assim, o tempo inteiro isso acontece. Esse ano, eu até te contei, também, esse ano aconteceu uma situação numa outra turma de Ensino Fundamental; não é restrito ao Ensino Fundamental, é que eu "tô" me lembrando agora, de uma agressão verbal, de uma violência, na verdade, uma violência verbal, de um grupo de meninos contra um grupo de meninas, e essa violência verbal, um dos... uma das coisas em que ela se... baseava, vamos dizer assim, é em colocar aquelas... partia dos meninos, em colocar aquelas meninas num lugar de "quaisquerzinhas". O termo usado foi isso, foi "suas quaisquerzinhas", no sentido de que tem um lugar da mulher que é valorizado, e um outro lugar da mulher que é diminuído.

Entrevistador: Uhum. 
Amanda: Que é menor, que é, talvez, sujo, que é, talvez, é... pra ser, assim... que pode ser escancarado, que pode ser humilhado. Então, assim... isso "tá" acontecendo o tempo inteiro. (pausa para uma respiração mais profunda)

Se eu tiver sendo muito é... fugindo assim, voando muito...

Entrevistador: Não, você "tá" sendo sensacional!

Amanda: Não, mas fala um exemplo, “cê" me situa.

Entrevistador: Não, Amanda, tá tranquilo! Eu quero que você seja aberta mesmo!

Amanda: Porque eu viajo, né?! (risos).

Entrevistador: Até porque, assim, a gente vai pegar a entrevista e não significa que a gente vai usar e...

Amanda: Sim, sim.

Entrevistador: E tem que ter material pra saber o que a gente vai coletar.

Amanda: Claro!

Entrevistador: "Tá” excelente, Amanda, fica tranquila! Eu vou mudar um pouco agora.

E racismo dentro da escola, "cê" já presenciou? "Cê" acha que tem o que falar sobre?

Amanda: O tempo inteiro. Aí eu podia repetir quase tudo o que eu falei a respeito de gênero e sexualidade em relação a racismo. A escola, como em outros espaços institucionalizados - e não - da sociedade, "tá" acontecendo o tempo inteiro. É, hoje eu "tava" pensando a respeito disso, eu não lembro mais o que me disparou, mas foi alguma coisa aqui da escola, talvez eu lembre. Alguma situação que aconteceu dentro de sala de aula. É... e aí eu "tava" pensando assim, no quanto que a gente é... sensível, eu acho que isso vai da experiência humana... É, acho que isso vai da experiência humana mesmo. O quanto que a gente consegue se sensibilizar e questionar e problematizar quando toca a nossa pele, aquela coisa de "nossa, eu senti na pele", e o quanto é um esforço muito grande pra gente conseguir se sensibilizar quando toca a pele do outro, né? Não sentir na pele passa muito batido...

Entrevistador: Sim.

Amanda: E aí eu pensando a respeito disso, eu pensei, por exemplo, - só um exemplo dessas muitas coisas que nos constituem, quem somos, são muitos exemplos - o quanto, muitas 
vezes, me passou tão batido circunstâncias muito parecidas a respeito, por exemplo, de racismo, ou a respeito de intolerância com outra religião, ou a respeito de uma intolerância em relação à sexualidade do outro ou ao gênero do outro, o quanto que muitas vezes, numa circunstância, me passou, assim... nem me passou. Passou tão longe de mim que nem me passou. E outras vezes, eu consegui perceber. Mas, muito é... por conta disso. Porque quando a gente não sente na pele, às vezes a gente acha assim “ah, não acontece, não!”. Era esse ponto que eu queria chegar! Entendeu? "Ah, não, que isso, gente! A gente tá em 2019, 'cê' vai me falar, Alexandre, que tem racismo? Ah, 'cê' é bobo, isso é coisa de antigamente". Porque muitas, muitas vezes, se a gente não sentir na pele, e às vezes a gente tá sendo...

Entrevistador: Deixa de existir...

Amanda: É... Às vezes a gente tá sensível pra uma questão, porque aquela a gente sente na pele, e uma outra questão, também social, não. Porque "ah, não, isso não existe mais". O tempo inteiro é uma enxurrada. É só sensibilizar o olhar, sensibilizar o ouvido, que você percebe. Você percebe no que você vê, porque, às vezes, não é o que é dito; é um olhar, é uma maneira de tratar, é uma exclusão; como você percebe no ouvir, também. Aquilo que não é dito diretamente, é aquilo que "tá" nas entrelinhas, a piadinha, ou o não dizer algum coisa... Em outras circunstâncias seria dito, mas naquela eu não digo, porque o tempo inteiro "tá" acontecendo.

Entrevistador: Uhum. E, na escola que você trabalha, nas escolas, né, que você trabalha, que é mais de uma escola. Você vê representatividade nesse sentido? Professoras negras, diretoras negras...

Amanda: Minorias, sempre. Sempre minorias. É... há a presença de figuras que ocupam esse lugar da representatividade, mas elas ainda em minoria quantitativa, ainda ocupando um espaço de minoria é... porque são muito sufocadas pelo dito e pelo não dito, pelo feito e pelo não feito, pelo que fica nas entrelinhas, pelo que é escancarado... Então, é um espaço carente, sim, e é um espaço que, assim, aí quando a gente vai pensar nisso, a gente pensa assim: "por que ainda é carente? Porque gente...” É... enquanto nação, olha quanto tempo que a gente vem se constituindo, enquanto democracia, olha quanto tempo que a gente vem se constituindo, enquanto, é... direitos humanos, enquanto... é... tantos debates já "tão" aí há tanto tempo, mas, né, tem muitas forças que elas querem amarrar no chão mesmo, né? Aí, essa briga de forças.

Entrevistador: Agora, outro tema. "Tá" achando muito rápido a mudança de tema? 
Amanda: Não, "tô" indo! (risos).

Entrevistador: Sobre a comunidade LGBTQIA+. Como é tratado na sua escola? A escola fala sobre isso? Tem alguma representatividade?

Amanda: Existe uma resistência, aí eu vou generalizar, e ao mesmo tempo eu "tô" falando dos espaços em que eu frequento, né? Existe uma tendência muito forte, especialmente, se fortalecendo nos últimos anos, não à toa, de diminuir o pouquíssimo espaço que já havia sido conquistado. Então, assim, eu já presenciei, eu já fui personagem de situações assim. Essa primeira turma que eu citei de Ensino Fundamental, em que eu sentia muita agressividade deles e, ao mesmo tempo, eu pensava assim: “essa agressividade é agressividade, sim, mas é agressividade de falar assim: que que é isso? O que é tudo isso?". E aí, de haver uma resistência hierárquica do tipo assim, "ah não, mas esse assunto aqui a gente não pode abordar, não... Porque se a gente abordar esse assunto aqui... 'noooossa'! Vai chover pai aqui na recepção. 'Noooossa', lá na Superintendência, o que vai ter de denúncia! 'Noooossa', o que vai dar de falar na internet, JF da depressão... Só vai dar o nome da escola”. Tem vários espaços que eu frequento, eu já fui personagem desse diálogo.

Entrevistador: Tentar estabelecer um diálogo e ter resistência.

Amanda: Um corte mesmo, tipo assim: "nem na sua aula 'cê' abre a boca pra falar disso, hein? Porque 'cê' vai arrumar problema e não é só pra você, não, então, não ouse.” Então, sim, há uma resistência muito grande, é... há muitas pessoas muito motivadas, muito interessadas em escavar esses espaços e defender que os espaços já criados não mínguem, não sejam desfocados, mas há uma resistência muito grande que esse espaço tem dentro da escola, é absurdo, assim.

Entrevistador: E "cê” já presenciou alguma cena de homofobia?

Amanda: O tempo inteiro.

Entrevistador: Mesmo diálogo dos outros, né?

Amanda: Ah! O mesmo diálogo.

Eu queria falar um negócio, posso?

Entrevistador: Não, eu só "tô" vendo se tá gravando... (risos).

Amanda: Em relação a isso mesmo. É... em uma das escolas que eu trabalhei recentemente, recentemente também, há cerca de dois anos, a gente recebeu um aluno que vinha em três 
anos, em três anos; em um ano era a terceira escola, se eu não me engano, ele tava no último ano do Ensino Médio, já nos meses finais, concluindo o Ensino Médio, com nota de PISM, tentar faculdade, vontade, desejo de fazer Ensino Superior e tudo mais, e duas escolas que havia passado antes, ele saiu das duas escolas porque ele tinha sofrido é... com discursos e com ações de transfobia e de homofobia pesadíssimas. Sempre é pesadíssimo, né? E assim, inclusive de... eu não sei se eu podia falar isso, mas posso, inclusive dos professores dele dizerem pra ele coisas do tipo assim "ah, "cê' vai pro inferno", "nossa, mas você era uma menina tão linda". Tratarem ele pelo artigo feminino o tempo inteiro e se recusarem, apesar dele ser um rapaz, se recusarem a ter esse respeito com ele, com a pessoa que ele era. E pra mim foi engraçado, porque eu conheci ele na entrada de uma dessas instituições; e aí ele virou pra mim e falou assim "você é professora aqui?", eu falei assim "sou”, aí ele falou assim "ah, então, eu 'tô' tentando uma vaga, você sabe se tem vaga pro terceiro ano? Porque eu 'tô' tentando uma vaga, 'tô' querendo 'vim' estudar aqui'. E aí a gente teve aquela conversa de dois minutos. Em outro momento, semanas depois, eu já nem lembrava mais de ter encontrado com ele, a diretora dessa escola me encontrou em um momento que eu "tava" em reunião com a supervisora e falou assim: "olha, nós temos um assunto muito delicado pra tratar. Eu vou chamar aqui uma pessoa que 'tá' matriculada aqui na escola e 'tá' vindo hoje pelo primeiro dia. Era uma menina, mas agora é um menino. Então, a gente vai ter que saber como lidar com isso.” Aí, 'tô' eu lá sentadinha, com a minha perninha cruzada (risos), entra o rapaz que conversou comigo no portão. E aí eu fiquei pensando assim "cara, a gente não sabe, a escola não sabe receber". A escola não sabe. Aí, vem o problema do nome social, aí vem o problema do banheiro, que banheiro que usa, aí vem o problema de a turma não pode saber, e o menino tá "cagando" pra isso. Pra ele não fazia diferença... Ou fazia, mas não fazia diferença esconder. A gente não sabe lidar.

Entrevistador: E... "cê" acha que o professor de Matemática sabe menos ainda do que outros professores? Quando a gente fala dos professores, por exemplo, da área de Humanas?

Amanda: Não...

Entrevistador: Você acha que é um geral, assim?

Amanda: Acho que a gente não sabe lidar e ponto final (risos). Ou, pelo menos, um ponto e vírgula (risos). Mas, não. Não, porque o que que acontece: tem, sim, um certo pensamento, tem, sim, uma certa inclinação? Tem. Alexandre, tem. O que te faz escolher Exatas ou Humanas... Tem. Um certo jeito de pensar que reflete no seu jeito de ver a vida, de ver o 
mundo e de ver o outro e tudo mais. No entanto, não há garantias. Então, assim... é... a mesma... o mesmo, digamos assim, o mesmo corpo docente que uma área de ensino, ali, pode se posicionar super do tipo assim, “olha, eu não 'tô' sabendo lidar, não, mas 'vamo' junto?" ou então assim "mas, eu vou aprender, pera aí que eu vou aprender, pera aí que eu preciso..." O problema "tá" em mim que não sei lidar com o outro. O problema não "tá" no outro. Você pode ter uma outra área de ensino que, pressupostamente - a gente pressupõe - que são super abertos, super descolados, assim no sentido de conhecimento, de malemolência, de jogo de cintura, de saber lidar mesmo com, por exemplo, receber um aluno transsexual que não sabe, e que cria resistência e que tem ali umas convicções, assim, muito assim... duras, muito... é... de exclusão, muito de... eu vou falar: não aceitação, porque pressupõe-se que é algo a ser aceitado.

Entrevistador: Eu ia te perguntar, agora, Amanda, sobre o que você pensa do papel da mulher na sociedade. Mas "cê" já falou bastante coisa em gênero e sexualidade, como eu te perguntei. Você tem alguma coisa a adicionar neste tema? Se você vê alguma diferença na composição dos espaços entre mulheres e homens, composição de salários, de cargos e alguma coisa assim?

Amanda: Gritantes, também, né? Eu acho que o papel... é... das minorias, mas não juntando todo mundo no mesmo saco, porque não tem como - que temos nossas especificidades, digamos assim, como grupos - é... esses espaços, eles são... usurpados, marginalizados o tempo inteiro, né? E aí, diferença salarial, de oportunidade de trabalho, de ascensão profissional, de lugar que "cê" pode frequentar. Não precisa nem ser em relação a trabalho...

Entrevistador: A maneira que você pode se vestir...

Amanda: A maneira como você pode se vestir e se comportar... é... de que maneiras você pode se relacionar com outras pessoas nas diversas relações que a gente estabelece com o outro, seja familiar, seja de amizade, seja amorosa, seja de chefe e funcionário, de aluno e professora, ou aluna e professor. Então, assim: pros diversos grupos que a gente, né, eu chamo de... não sei se "tá" errado falar isso, mas que eu chamo de minorias, esses espaços são, bem generalizando mesmo, eles são espaços 'beeem' saqueados mesmo, bem... digamos, colonizados pelo que "tá" instituído como padrão. Aí a gente pode falar do padrão de cor de pele, do padrão de gênero, de sexualidade, de... é... de lugar que "cê" nasceu, de classe social, né? 
Entrevistador: Última questão, foi rapidinho, né?

Amanda: Foi?

Entrevistador: "Cê" "tá” nervosa?

Amanda: Eu "tô", eu "tô" tímida (risos).

Entrevistador: É, ô, Amanda...

Amanda: Eu "tô" focando ali na bandeira, isso aqui "tá" uma loucura (risos).

Entrevistador: Mas, Amanda, eu já falei isso até com o Léo, cara "cê" tem uma oratória que a gente fica, assim, olhinho brilhando...

Amanda: Eu "tô" suando, mas não é porque a sala "tá" fechada, não...

Entrevistador: É, ô, Amanda, agora é... Considerando isso tudo que a gente conversou até aqui: você, você já sofreu algum tipo de opressão dentro de um ambiente de trabalho, ou então, na sua trajetória escolar? Como que foi isso?

Amanda: Sim, é... eu... no ambiente de trabalho eu já vivi anos em um mesmo ambiente de trabalho em que eu não conseguia falar em reunião nenhuma. Eu não conseguia falar, porque a partir do momento que eu abria a boca, é... havia uma figura (risos) que levantava a voz pra falar mais alto, junto comigo, e sobre outro assunto. E havia uma força nessa figura e nessa postura assumida que eu nunca conseguia terminar o meu raciocínio; às vezes, eu não conseguia nem começar a falar direito. Então, eu passei por isso durante muitos anos, sabe? E... "tô" nomeando como uma figura, mas era a figura de um homem branco, da área de Exatas... é... heterossexual, cristão, cisgênero, com mais experiência, com mais títulos acadêmicos... Então, tinha muita coisa que constituía esse homem e que eu não... "Ah, nada a ver", mas tinha tudo a ver com o fato de eu nunca conseguir falar e tinha tudo a ver com o fato dele, de fato, roubar o meu momento de me posicionar. E podia ser o assunto que fosse. Podia ser "a gente compra um bebedouro branco ou um prata?" ou podia ser "vamos mudar o currículo de Matemática da escola?”, sabe? Então, sim, nesse sentido, sim. É... enquanto aluna de escola, inclusive, eu tive um momento em que eu fui... uma determinada situação, em que eu fui... na época, eu devia ter uns 15 anos; então, na época, eu não entendia, eu falava assim “isso aqui 'tá' esquisito, isso não era pra 'tá' acontecendo dessa maneira, isso não era nem pra 'tá' acontecendo". Mas o que "tá" esquisito aqui eu não sabia. Então, a minha postura foi assim: resistir e resistir, entendeu? Mas, eu não sabia nem de que maneira, porque eu não 
"tava" entendendo nem o que "tava" acontecendo. Mas, a situação foi essa, sim, de eu ser orientada em relação a um... Aaaah! Em relação a um professor de Geografia! (risos). Agora que eu lembrei! De Humanas (risos), a respeito de com quem eu deveria me relacionar amorosamente. Porque do jeito que eu "tava" fazendo não "tava" bom, não. É... então teve isso enquanto aluna. E eu senti muito no curso de Matemática que havia uma predileção pelos meninos nas matérias de Matemática Pura, matérias do ICE, especialmente, mas as mais de Matemática Pura, ministradas por professores homens, eu senti essa predileção. Eu nunca passei pelos casos que a gente sabe, também, que "tá" assim... de assédio, ou de discriminação de gênero dentro da universidade. Ou, se eu passei, eu não identifiquei, né? Mas, a gente sabe, também, que "tá" borbulhando, "tá" o tempo inteiro acontecendo, mas eu tive essas duas situações profissional e escolar.

Entrevistador: Excelente! Muito obrigado, Amanda, pelo seu tempo e pela sua disponibilidade.

\section{ENTREVISTA 2}

Entrevistador: Ivani, olha só: eu vou pôr pra gravar e eu vou fazer umas perguntas, e a gente vai só conversando assim mesmo.

É... primeiro, eu vou falar que ninguém vai saber que você que deu a entrevista, então, eu quero que "cê" se sinta bem à vontade pra falar tudo que você quer falar. Todas as falas vão ser representadas por atores, então, assim, é... todo mundo "tá" se sentindo super à vontade pra falar, porque não vai aparecer nome, não vai aparecer nada. Completamente anônimo, tem até um termo que antes de lançar o documentário a gente vai assinar.

E qual que é a ideia? Através dos depoimentos, tentar passar, de uma forma mais imparcial, os assuntos que a gente não fala dentro da sala de aula. E por que que a gente não fala? Por que deve falar? Ou, tem que falar, ou não tem que falar? A gente não "tá" aqui pra falar “Ah, tem que falar ou não tem”; a gente só quer abrir discussão. Porque tem muitos assuntos que a gente não conversa e fica por isso mesmo, assim, ou, então, tipo assim, acha que a gente não pode ouvir a pessoa falar que não concorda e já vira uma briga imensa. A gente não quer isso; a gente só quer tentar abordar tudo e tentar chegar num consenso do que é correto um professor falar e abordar na sala de aula e o que não é correto um professor abordar na sala de aula. Aí, assim, eu vou perguntar através de uns temas e eu quero que "cê" 
fale sinceramente o que "cê" pensa, sem papas na língua, pode ser, assim, do jeito que você pensa mesmo, até por esse respaldo de ninguém vai saber quem falou o quê, né?

Aí, a primeira pergunta é: você acha que um professor tem que abordar o tema, por exemplo, de racismo dentro da sala de aula?

Ivani: $\mathrm{Eu}$, sinceramente, acho todos os assuntos extremamente naturais, e isso vem naturalmente, por quê? Porque primeiro que eu acho muito difícil existir um branco nato, né? Já não existe, na sociedade, mais um branco nato.

Entrevistador: Ainda mais no país que a gente vive, né?

Ivani: Ainda mais no país que a gente vive, né? Então, assim, é muito difícil, Alexandre, não abordar ou deixar de puxar. Eu só acho que as coisas têm que ser ditas naturalmente e, principalmente, eu acho que a Educação Infantil, a primeira educação, quando as coisas começam a se formar na cabeça dos alunos, é... as diferenças têm que ser apontadas na infância. "O seu olhinho é diferente do olhinho dele"... é... a sua sobrancelha é diferente, o seu ombro é diferente, a sua altura é diferente, o tipo de rosto é diferente, os dedinhos são diferentes, entendeu? Eu acho que falta isso muito na escola básica do Brasil.

Entrevistador: Pra que se crie o respeito às diferenças desde cedo, né?

Ivani: Naturalmente às diferenças e, principalmente, com relação aos aspectos - "vão" falar assim - não são raciais, não, econômicos mesmo, financeiro e consumismo, entendeu? Porque a partir do momento que sua unha é diferente, seu dedo é diferente, por que que "cê" não vai ser igual? Então, assim, na infância não é tratado as diferenças humanas. Então, acaba as crianças e os jovens... é... daqui a pouco, o mercado coloca você num capitalismo, numa forma de competição tão grande que aí você não se toca mais que você não é diferente, aí, "cê" tem que ser igual.

Entrevistador: Sim.

Ivani: Quando você tem, você vai ter que ser igual de uma forma abrupta, agressiva, numa época que você "tá" cheio dos hormônios, jogando tudo pra fora. Se isso fosse trabalhado na infância, normalmente - não é só cor de pele, eu acho que esse é um detalhe, entendeu? - Se fosse cor do cabelo, tamanho da orelha, tamanho da perna, os seus dedinhos do pé, o seu nariz, o seu rosto, o seu olho, a cor da pele entraria naturalmente, entendeu? Tudo entraria, normalmente na infância, e, então, daqui a pouco, "cê" "tá" na juventude quando jogar tudo na sua cabeça que existe um Neymar, uma Gisele Bündchen, existe tudo, você iria falar "Mas 
eu não sou igual a ninguém". Então, você começaria a falar assim "Um tem dinheiro e outro não tem", porque eu não sou igual a ninguém. Eu não sou pior e não sou melhor. Porque também existe o melhor - que também é uma doença horrorosa, né? - Então, assim... - doença da pessoa se sentir acima de todos, né?

Então, psicologicamente, eu acho muita afetação numa hora que não poderia ter isso, porque é a hora que os hormônios "tão" todos aflorados, a hora que você já faz o que quer da vida a partir de 12 anos de idade - com mentira, com verdade, "cê" vai fazer o que "cê" quer da vida -. Aí, você pode entrar "prum" tráfico, aí você pode ser racista, aí você pode ser homofóbico. Aí, você pode tudo, porque os poderes estão soltos, né? Porque nunca foi trabalhado as diferenças. Eu acho isso crucial na educação brasileira.

\section{Entrevistador: Sim.}

Ivani: Eu nunca vi, no Ensino Fundamental, o uso das diferenças.

Entrevistador: Sim.

Ivani: Entendeu? Então, assim, vai acontecer e vai "tá" em qualquer época da vida da gente, né? O racismo na infância, o racismo na adolescência, o racismo no Ensino Superior, tudo vai ter. E as pessoas "tão" faltando com respeito porque não "entende" que não tem ninguém igual.

\section{Entrevistador: Sim.}

Ivani: Né? Então, assim, não é racismo só tom de pele. É o japonês, o índio, né? Ao mulato, ao ruivo, à loira, entendeu? Então, assim, o racismo como... é... que a gente introduz e lida como só o negro - o racismo contra o negro - ele é o mais violento e ele é muito forte no Brasil.

Entrevistador: Muito forte.

Ivani: Muito, isso é indiscutível. E se você falar de uma pessoa de 20 anos de idade, ele entende isso como muito mais violento do que se falar com uma pessoa com 40 anos de idade, se falar com uma pessoa de 60 anos de idade. Eles... o de 60 anos de idade já viu tanta coisa na vida, que hoje ele vai falar que quase não existe.

Entrevistador: É verdade. 
Ivani: $\mathrm{O}$ de 40 anos de idade já viu uma parte da vida, porque ontem foi a escravatura. Então, ele já viu uma parte tão violenta, que hoje ele vai falar "Quase não existe". E o jovem, hoje, a gente vê como uma coisa muito violenta que pra outros quase não existe.

Entrevistador: Sim.

Ivani: Então, assim, pra quem olha de fora - vamos falar, assim, uma fotografia - existe, é fato, é horroroso, tem que ser dito, falado o tempo inteiro e combatido, porém, historicamente, o avanço foi INCRÍVEL, e quem tem 60 anos vai te falar assim "Quase não existe, porque 'cê' não sabe como era na minha infância".

Entrevistador: Sim.

Ivani: Então, essa mudança "tá" muito grande, né? Essa mudança "tá" muito acelerada perto do que a gente nem imaginava de existir. Se há 60 anos atrás você falasse assim: "Eu estou sentado, eu e mais quatro negros, uma ruiva, um homem, uma mulher", vou falar "Não existe". Entendeu? Então, assim, eu acho muito rápido tudo isso, historicamente. Porém, pra educação brasileira, que a grande maioria "tá" em torno de 20 anos, - "vão" falar os 20 anos de idade - eles "tão" achando isso lento e isso muito cruel, e isso deveria ser combatido, e muito forte. É todos os dias, todas as horas, todo tempo, mas, principalmente, você partindo de você. Tá?

Entrevistador: É... outra pergunta agora, Ivani. Todas as perguntas que eu vou fazer pra você, eu fiz pra todo mundo igual, sem pôr nem tirar, tá?

Ivani: Uhum.

Entrevistador: Você acha que as cotas, o sistema de cota pra entrar na faculdade, é um sistema válido? É falho? Tem que melhorar? Já "tá" bom do jeito que "tá"? O que que você pensa sobre isso?

Ivani: Ela foi criada, Alexandre, em 1986, mais ou menos... 96, mais ou menos, né? Pra ser durante um período. Extremamente válida. Porque não existiam negros nem nas escolas particulares. As únicas escolas que ainda tinham o negro comumente com os brancos ainda eram as escolas militares. O resto não tinha negro com branco.

Entrevistador: Uhum.

Ivani: Porém, o que a política pública tinha que ter chegado num nível que ela acabasse. Como não chegou, ela tem que continuar. 
Entrevistador: Que é a equidade de ensino, né?

Ivani: É. Ela só tem que continuar por causa de uma falha da política pública de colocar em pé de igualdade as coisas. Vinte anos não deu pra fazer isso. Então, ela tem que continuar.

Entrevistador: Uhum.

Ivani: Agora, a falha é enorme. Porque onde tem ser humano, tem falha. Então, assim, entra errado, justifica errado... é... tribo indígena com duas mil pessoas com sete mil dentro da universidade... Então, a partir do momento em que existe trambique, é meio que assim, "Para tudo e 'vão' recadastrar".

Entrevistador: Sim. O branco pegando cota do negro, né, e não comprova. Aí, tira a oportunidade de um negro estudar na faculdade. Tem falhas no sistema.

Ivani: Negros riquíssimos. Então, assim, eu sou a favor da cota social, porque a cota social iria entrar todos os negros de baixa renda, entendeu? Que tivesse escalas - eu nunca estudei sobre isso, eu não sei como eu faria isso. Mas, eu sei que tem erros sérios. Do jeito que "tá", não deveria existir. Entendeu? Não é que não deveria existir a cota; não deveria ser como ela é hoje, entendeu? Por quê? Porque um branco pobre, hoje, quase que impossível de entrar numa faculdade, entendeu? Então, assim, ele não teve poder de escolha, ele não teve uma boa escola; às vezes, ele "tá" lá na roça, estudando na escolinha da roça, onde o professor mais falta do que vai. Aí, ele vai fazer, ele não é negro, ele não é nada, então, ele perde alguns direitos. Até porque, também, eu tenho que estudar hoje como estão divididas as cotas, e eu não sei, hoje, se é só escola pública; “Ah, é só escola pública”, tem que ter mais isso, mais isso. Isso eu não sei de cor pra te falar, entendeu? Mas, o que a gente vê são escândalos horrorosos, pessoas assim...

Entrevistador: Mal intencionadas...

Ivani: Filhas de médico que estão com cota de não sei o quê, ganhando bolsa de não sei quê. Então, isso assusta tanto que um errado tem que parar. Entendeu? Isso é a minha visão. Se uma pessoa morrer por alcoolismo, por uma pessoa bêbada dirigindo, que todos os motoristas sejam penalizados se ficar bêbado.

Entrevistador: Sim, entendo.

Ivani: Uma pessoa, uma família destruída, uma pessoa que se tire as possibilidades dela de evoluir na educação - não "tô" falando uma pessoa é uma pessoa - "tô" falando assim, aquelas 
pessoas não podem ser condenadas a não poder continuar por causa de um sistema que "tá" falho.

Entrevistador: Sim, verdade.

Ivani: Entendeu? Porque se você fosse uma delas, você iria sentir na pele.

Entrevistador: Sim.

Então, numa visão geral, é mais válido uma cota social do que uma cota racial?

Ivani: Sim. Sim.

Entrevistador: Porque acaba que a cota racial nem contempla o que tinha que contemplar.

Ivani: Não, até porque, quando se fala de minoria, hoje, a população brasileira tem $52 \%$ de negros.

Entrevistador: Negro é maioria.

Ivani: Então, já "tá" na maioria. Dessa maioria, qual teve como estudar? Aí, todos eles vão falar assim: “90\%, 98\% ‘tão’ em escola pública”. E todos os brancos, 98\% também “tá” em escola pública. "Tô" falando, assim, pobres. "Vão" falar assim, a classe é... econômica baixa, no Brasil, está em escola pública. Onde tem 50 e tantos por cento de negros e 40 e poucos por cento de branco.

Entrevistador: Sim.

Ivani: Passando pelas mesmas escolas.

Entrevistador: Sim.

Ivani: Onde a mãe é uma empregada doméstica que o pai abandonou e... Então, qual o critério? Vinte anos se passaram.

Entrevistador: Sim, e continua a mesma proposta de quando foi criada.

Ivani: A mesma proposta, né? Então, assim, eu não sou contra A cota, em hipótese alguma. $\mathrm{O}$ governo não fez a parte dele, nós temos que manter a cota. Tem que ser revisado o sistema de cotas.

Entrevistador: Sim, até que o governo crie políticas públicas pra contemplar todo mundo mesmo, né?

Ivani: Contemplar todo mundo socialmente falando. 


\section{Entrevistador: Sim.}

Ivani: Né? Porque eu não posso pegar um filho de um negro rico e comparar com um filho de um negro pobre simplesmente pela cor. Existe essa diferença de cota que, hoje, eu não sei quais são; também, nós estamos falando só do negro, né?

Entrevistador: Sim, é.

Ivani: Mas...

Entrevistador: Não, mas existe. Ampla concorrência, que é quem não estudou em escola pública, só estudou em escola particular; a cota racial... tem... - aí, eu também não sei se inclui a cota indígena dentro da racial, se tem algumas vagas pro índio. Tem pra pessoas com deficiência e tem renda. E tem escola pública.

Ivani: Uhum.

Entrevistador: Porque tem duas separadas, tem uma assim, ó: "Até um salário e meio mínimo na família/estudante de escola pública"; e outra, "Escola pública independente do salário da família.".

Ivani: Uhum, da renda. É. Mas, tem o que a gente vê hoje que a escola pública, que é um sistema de cota, né - o sistema de cota de escola pública de Ensino Médio - o que "tá" levando milhares de pessoas com poder aquisitivo alto ir pra escola pública pra contemplar essa cota.

Entrevistador: Sim.

Ivani: Então, nós estamos falando de sistema de cota. O que eu sei é que pessoas de poder aquisitivo alto - não "tô" falando nem cidade grande, que cidade grande já entra escola pública perigosa -. Não, eu estou falando de cidade pequena. A maioria das pessoas vão pra escola pública. "Cê" vê que o número de turmas nas escolas públicas no primeiro ano do Ensino Médio quadriplicam, porque eles já sabem da cota de ensino público.

Entrevistador: Sim, exato.

Ivani: Né? Então, é um sistema de cota? É um sistema de cota. Falho.

Entrevistador: Tem gente do Colégio Militar que compete com pessoas de Estadual, também.

Ivani: Que o nível de ensino...

Entrevistador: Cobrança, né? 
Ivani: É, é completamente incompatível.

Entrevistador: Tem muita coisa pra melhorar.

Ivani: Entendeu? Então, assim, essa é a minha opinião, assim, de quem "tá" vendo. Se foi criada pra ser combatido algum... algum... como se fosse um pedido de desculpas social de ter discriminado essas pessoas, deixou de discriminar e colocou um bando de pessoas pra ser, mentir.

Entrevistador: Sim, concordo.

Ivani: Isso é hipócrita, entendeu? Então, não.

Entrevistador: Do jeito que "tá", não.

Ivani: Do jeito que "tá”, eu sou contra. Contra a cota, não, contra o sistema.

Entrevistador: Sim

Ivani: A favor da cota eu sou.

Entrevistador: Entendi.

Agora, Ivani, mudando um pouco o tema: "cê" acha que as escolas e o professor de Matemática, pensando sempre que a gente dá aula de Matemática, tá? Pra ver se a gente tem que se incluir nesse quadro de pessoas que podem ou não falar disso. "Cê" acha que tem que abordar tema como Gênero e Sexualidade dentro da escola?

Ivani: Qualquer pessoa. Qualquer pessoa que tiver um senso de honestidade e crítica e realidade da sociedade, ela pode abordar. Né? Nós não podemos falar de uma pessoa completamente ignorante no assunto querer abordar.

Entrevistador: Sim.

Ivani: Independente se ele é professor ou não. Se ele é médico e for ignorante no assunto, ele não pode abordar.

\section{Entrevistador: Sim}

Ivani: Entendeu? Então, são todos os profissionais que podem abordar o assunto? Não. Nem professor, nem médico, nem engenheiro e nem o operário. Qualquer pessoa pode abordar o assunto desde que ele tenha conhecimento e seja justo com o que a sociedade, hoje, expressa? Qualquer pessoa. 
Entrevistador: Sim, porque a minha dúvida, na verdade... (corte/interrupção pela entrevistada).

Ivani: E a qualquer tempo. Se cometer... é a mesma coisa se falar assim: “Ô, Alexandre, toma conta de uma creche de todas as crianças de cinco anos. "Ah, não pode subir ali". Você não pode falar isso com os filhos de tais pessoas e pode falar com o de tais pessoas. Ou é pra todos, ou pra nenhum.

Entrevistador: Sim.

Ivani: Se for pra queimar o dedo mexendo na tomada, eu, como adulto... "Ah, mas isso é uma parte elétrica, eu não posso falar, que eu não sou eletricista”. Não dá, não dá.

Entrevistador: Não vai abordar, né?

Ivani: Eu tenho que chamar a atenção e tenho que expor se eu tiver conhecimento daquilo.

Entrevistador: Sim, entendi.

Ivani: Qualquer pessoal responsável pela outra ou pela sociedade. Porque o professor, pra mim, ele exerce uma função social muito maior do que dar aula.

Entrevistador: Sim.

Ivani: Só que você não precisa ter só o valor universitário pra fazer isso, entendeu?

Entrevistador: Sim.

Ivani: Agora, dentro de uma sala de aula é onde "tá" formigando e trazendo todos os assuntos sociais o tempo inteiro. É um reflexo da sociedade. É um reflexo de casa, é um reflexo do bairro, é um reflexo de qualquer lugar...

Entrevistador: Familiar... É, sim.

Ivani: Familiar... Então, ele vai borbulhar onde? Na escola. Aí, "cê" vai fingir de morto e não vai falar no assunto? Agora, qual assunto? Despejar de qualquer forma e sem conhecimento?

Entrevistador: Sim.

Ivani: Porque a maioria dos professores também não tem o conhecimento pra falar.

Entrevistador: É, verdade.

Ivani: Tanto que eles levam susto.

Entrevistador: É. 
Ivani: Entendeu? E quando fala, tipo assim, "Não aconteceu nada, não, é todo mundo igual, é todo mundo igual, é todo mundo bacana, ou, todos nós somos diferentes.”. Mas, por quê?

Entrevistador: Por que que você acha que aonde tem uma formação nesse sentido até dentro da universidade?

Ivani: Sim.

Entrevistador: Assuntos com esse, disciplinas com essa? Porque a gente que faz Matemática a gente não vê nada disso, né?

Ivani: Quais os assuntos que vão ser trazidos?

Entrevistador: Que podem surgir na sala de aula?

Ivani: Como abordar esses assuntos?

Entrevistador: Uhum.

Ivani: $\mathrm{Ou}$, pararam... Até a hora de parar um assunto até ter conhecimento?

Entrevistador: Sim.

Ivani: Abordar por abordar? Entendeu? Então, eu não tenho conhecimento, por exemplo, de transgênero. Eu não tenho conhecimento clínico, físico, emocional. “Ô, gente, 'vão’ fazer o seguinte? Eu não tenho conhecimento sobre esse assunto, mas eu exijo que tenha respeito. Vamos parar, e eu vou trazer uma pessoa pra conversar com vocês; eu vou trazer na escola quem puder, quem quiser." “Vamo"” conversar no meio de um médico, de um psicólogo, de um psicopedagogo?".

Entrevistador: Que tenha o acompanhamento necessário, né?

Ivani: E eu tenho que ser humilde o suficiente pra falar "Não entendo, não sei".

Entrevistador: Sim. Porque, na verdade, assim, a questão de gênero ficou clara a sua opinião. Agora, a questão da sexualidade, a gente escuta muito, Ivani, as pessoas falarem que, na verdade... é... a sexualidade é ensinar às pessoas como faz sexo, entendeu?

Ivani: E não é.

Entrevistador: É, e não é. Era isso que eu queria saber da sua opinião, assim, em relação a isso. 
Ivani: Se tem que falar sobre... Se tem que falar sobre homem e mulher? Sobre sexualidade? Se você tiver conhecimento e propriedade do assunto, sempre. Independente de eu ser professor da área. E as escolas têm que falar - "vão" falar assim - clinicamente... é... têm que falar fisicamente... é... têm que falar emocionalmente e familiarmente. Isso as escolas têm que falar.

Entrevistador: Sim.

Ivani: E se você tiver condição melhor ainda de preencher os assuntos, ali, de forma... Não é técnica; que, muitas vezes, é emocional, mesmo, né?

Entrevistador: Sim.

Ivani: Mas, quanto mais conhecimento você tiver... Como que a gente vai abranger todas as áreas, gente?

Entrevistador: É. Exato. Tem que ter amparo de pessoas que realmente entendem do assunto.

Ivani: Entendeu? Então, assim, é difícil pra quem nunca viveu e nunca conheceu.

Entrevistador: Sim.

Ivani: Então, você é um professor de Matemática. Já viveu, já conheceu, já se informou? Entre no assunto.

Entrevistador: Sim.

Ivani: Se você é um professor de Biologia, só sabe a parte teórica, nunca viveu, nunca passou e não tem condição, dá a parte teórica e chama quem sabe.

Entrevistador: É. Porque, senão, também, fala qualquer coisa, né, achando que sabe e não é.

Ivani: Não é. Não é. Eu sou contra abrir a boca sem um respaldo pras exceções.

Entrevistador: Sim.

Ivani: Porque "cê" vai chegar numa hora ali que o menino vai falar assim: "Pois é, mas meu pai transa com a minha irmã". "Cê" conhece esse assunto, Alexandre? "Cê" sabe isso psicologicamente? "Cê" sabe isso fisicamente? "Cê" sabe isso religiosamente?

Entrevistador: E quando você aborda com a pessoa sem saber, também, o tanto que isso vai... (corte/interrupção pela entrevistada). 
Ivani: Agredir ou incomodar a pessoa?

Entrevistador: Exato.

Ivani: Então, se você não sabe tudo, cala, para, "Olha, isso é um assunto, realmente, que eu não sei". Entendeu? Então, assim, o que eu vejo, hoje, é que todo mundo quer dar o "pitaco" e saber de tudo e não sabe.

Entrevistador: Sim, é verdade. Sem propriedade, né?

Ivani: Sem propriedade. E outra coisa: essa pessoa, o mínimo que "cê" pode dar é carinho e respeito até aonde você consegue ver. E o professor tem que ser educado pra isso.

Entrevistador: Sim.

Ivani: Entendeu? Até aonde que ele pode ir? Entendeu? E... segurar aquele menino com amparo dentro da sala de aula para que todos o respeitem, entendeu? Por isso que eu acho que o viés "tá" no respeito.

Entrevistador: Sim.

Ivani: "Tá" na criação, mas a criação não é dos pais, é uma criação educacional.

Entrevistador: Relação aluno e professor, também, né?

Ivani: A tudo. Entendeu? Porque se você pegar lá debaixo, você vai chegar aí, entendeu? Não sei como fazer, eu "tô" falando, assim, um feeling, um pedaço...

Entrevistador: Eles estão querendo, agora, colocar como se fosse uma disciplina de escola, Gênero e Sexualidade. "Cê" acha que tem que ter... tem que tirar, por exemplo, alguns assuntos que são abordados por vestibular e tal, pra colocar esse tipo de disciplina, nesse momento? Ou, você acha que é pra falar em momentos separados, assim?

Ivani: Eu... eu acho que... pra se colocar numa prova? (pausa). É, eu não sei, porque, assim...

Entrevistador: Não como uma prova, mas, como se fosse, assim... Não tem lá, sei lá, uma vez por semana não tem Artes? Vamos supor.

Ivani: Aham.

Entrevistador: Colocar, uma vez por semana, Gênero e Sexualidade pra abordar esses assuntos. 
Ivani: Pode. Eu acho útil. Sabe por que que eu acho útil? Porque, hoje, você conversa com qualquer menina de 12 anos de idade, de 11 anos de idade, que frequenta qualquer festinha, as meninas se beijam entre si e os meninos se beijam entre si.

Entrevistador: É, sim.

Ivani: Eu não sei o que que eles querem dizer e se nesse ponto ainda cabe a homossexualidade, a bissexualidade. Eu não sei em que ponto clínico, físico, psicológico cabem esses assuntos.

Entrevistador: Sim.

Ivani: Eu não tenho esse poder, entendeu? Eu não tenho capacidade.

Entrevistador: Entendi.

Ivani: Mas o que eu vejo... o que a gente vê é isso. Se vê isso, tem que ser conversado.

Entrevistador: É verdade.

Ivani: Entendeu? Então, assim, muitas vezes, eu vejo as pessoas comentando, por exemplo nas cidades menores, principalmente - "Ah, a Globo não tinha que abordar esse assunto na novela das oito que isso dissemina". Não. A Globo coloca na novela das oito o que existe.

Entrevistador: Sim.

Ivani: Existe na casa de todo mundo e o tempo inteiro, em qualquer lugar. Só que se na cidade grande isso corre primeiro... Entendeu? A visão social... eu não sei, entendeu? Então, assim, eu acho que tem que ser colocado tudo que se vê na sociedade, tem que ser colocado em assunto pra ser discutido.

Entrevistador: Sim. Agora, um exemplo que eu tenho usado nas entrevistas é um exemplo que ficou muito famoso aqui, em Juiz de Fora, que foi aquela questão daquela drag que foi fazer uma entrevista no João XXIII.

Ivani: Uhum.

Entrevistador: É... e tiveram pais que falaram que não concordam com esse tipo de abordagem. Você também acha que é válido o pensamento desses pais? De falar assim: “Olha, agora não é hora desse menino...”.

Ivani: Acho. Acho válido. 
Entrevistador: “...desse menino não ter contato com isso agora, porque ele tem, sei lá, 6 anos e ainda não precisa de...". (corte/interrupção pela entrevistada).

Ivani: Eu acho... Eu não acho que seja... O drag é sensacional, inteligente, culto e poderia ir em qualquer escola, a qualquer momento. A questão daquela época foi um assunto muito aflorado, porque foi antes de... Foi político.

Entrevistador: Foi.

Ivani: Quando há uma guerra política, eu acho que todos perdem.

Entrevistador: Uhum.

Ivani: Entendeu? A sociedade, em aprender, em conhecer. E, por exemplo, o LGBT... é... perder campo de... de disseminar uma qualidade, uma beleza, e outras coisas mais que ali teria ter trazido.

Entrevistador: Uhum.

Ivani: Então, como eu achei aquilo político - e é lógico que as coisas não "existe" hora, lugar, nem nada - mas, assim...

Entrevistador: Naquele momento...

Ivani: Naquele momento, no dia das crianças, politicamente peitar... Foi como uma forma de peitar uma sociedade, tipo assim, quer medir... medir, assim, vamos ver a aceitação ou não. Foi medir força.

Entrevistador: Sim.

Ivani: Entendeu? Então, assim, politicamente foi incorreto. Não ela ir numa escola.

Entrevistador: Sim.

Ivani: De jeito nenhum!

Entrevistador: Foi todo o contexto, né? Da época, do que tava acontecendo...

Ivani: É, foi um contexto, entendeu? Então, assim, uma drag, linda, maravilhosa, inteligente, culta, que tem tudo pra conversar, pra falar o que que ela sente, o que que ela faz e a arte de ser aquilo, foi quase que jogado como uma coisa péssima, horrorosa, mal vista, porque foi tentar medir força política.

Entrevistador: Sim. Verdade. 
Ivani: Então, assim, a hora e o lugar, todos nós temos que saber, "cê" entendeu? Então, assim, independente do assunto. É a mesma coisa que falar assim "Ah, o padre tal 'tá' no ‘puteiro', ‘vamo' lá confessar?”. Entendeu? Então, assim, para. Ele pode “tá” lá, pode? Pode não "tá" fazendo nada? Pode. Pode ser uma santidade explicando "praquelas" pessoas algumas ações, algumas coisas? É, mas, é hora lá de confessar?

Entrevistador: É, tem hora pra tudo, é verdade (risos).

Ivani: Entendeu? Então, para, pensa. Eu acho que tem outras formas de você colocar a sociedade em conversa.

Entrevistador: Porque essa forma não foi válida, né?

Ivani: Não foi...

Entrevistador: Não foi alcançada, né?

Ivani: Não foi... Não vou falar nem bonita, nem feia, nem útil, nem nada disso. Ela não atingiu o objetivo.

Entrevistador: Sim.

Ivani: E só perdeu.

Entrevistador: Uhum.

Ivani: Todas as partes.

Entrevistador: Porque foi o caso... (corte/interrupção pela entrevistada).

Ivani: A sociedade, o João, o LGBT, a drag como pessoa, "cê" entendeu? Colocou todo mundo ali, a drag como pessoa, entendeu? Então, assim, tudo que há a perder, eu não acho que deva entrar em disputa.

Entrevistador: Sim, entendo.

Aí, Ivani, "cê" chegou a falar da homossexualidade, da bissexualidade e tal. Você acha, também, que a escola tem que respeitar a opinião de um pai se ele virar pra ela e falar assim: "Olha, sou evangélico, a nossa família acredita nisso, então, eu quero criar meu filho debaixo desses parâmetros aqui pra ver se vai dar certo, e eu não quero que a escola tente influenciar ele de alguma forma.”. Entendeu? Falando sobre esses assuntos.

Ivani: Porque ele vai sempre entender como influência. 
Entrevistador: Uhum.

Ivani: O pai vai sempre entender como influência.

Entrevistador: Sim.

Ivani: Até porque chega em casa atravessados os assuntos.

Entrevistador: Sim.

Ivani: Entendeu? Então, eu não culpo um pai que entenda dessa forma. Então, assim...

Entrevistador: Até porque tem a criação dele, o jeito que ele pensa, a religiosidade...

Ivani: É, o menino vai chegar em casa e vai dizer o seguinte: "Hoje, a professora lá falou de transa, de...". Ele não vai falar de ato sexual...

Entrevistador: É, ele não vai usar os termos, né?

Ivani: Não vai usar nada.

Entrevistador: Sim.

Ivani: Então, é igual telefone sem fio. A coisa mal passada, ela vai ter reflexão diferente.

Entrevistador: Sim.

Ivani: O reflexo vai ser. Então, quando um... um... o pai nunca vai conseguir ter essa...

Entrevistador: $\mathrm{O}$ acesso ao que foi falado, realmente, dentro da sala.

Ivani: Não. E ele também nunca vai conseguir falar assim: "Eu quero criar meu filho de forma diferente". Ele não vai conseguir, porque a sociedade não vai deixar. Então, é ignorância do pai querer isso, né?

Algumas escolas, eu vejo, hoje, que eles falam o seguinte: "Dia tal, tal, tal, irão ser conversadas com as crianças tais, tais, tais assuntos"...

Entrevistador: Aí, fica a critério da...

Ivani: Quem não concorda... "Cê" não pode obrigar uma pessoa a concordar. Ao mesmo tempo, você vai falar com o pai o seguinte - na reunião, por exemplo: "O que vai ser dito 'tá' escrito nessas folhas.”. Entendeu?

Entrevistador: Sim. 
Ivani: Tipo assim, passar uma aula pros pais primeiro quando o assunto for... é... que possa haver constrangimento ou chegar como telefone sem fio, de forma diferente.

Entrevistador: Sim.

Ivani: Se você vai falar de gênero, se você vai falar de... transa, se você vai falar de relação sexual, se você vai falar de qualquer assunto, eu acho que tem que ser colocado pros pais antes.

Entrevistador: Sim.

Ivani: Pro telefone não chegar errado.

Entrevistador: Uhum. Ou, então, convida o pai a participar de uma aula experimental, né?

Ivani: Desse assunto. Vai ser mostrado esse slide...

Entrevistador: Deixa o pai lá um do lado do outro...

Ivan: Ou, às vezes, pra não constranger, assim, a primeira aula com os pais...

Entrevistador: "Olha, a gente vai falar exatamente isso", quem concorda?

Ivani: Tem alguma coisa demais em ser dito? Alguma coisa física, emocional, clínica que você não queira que seus filhos saibam?

Entrevistador: Sim, é válido.

Ivani: Entendeu? Aí, vai falar "Não, se for aula desse tipo, a gente concorda, a gente quer" ou "Não, meu filho, realmente, eu prefiro vocês falarem do que...". Eu preferiria uma pessoa falar tecnicamente um assunto normal do que meu filho me pegar com uma pergunta esquisita no meio do almoço com a vovó (risos).

Entrevistador: É, verdade.

Ivani: Então, coloca isso pros pais, entendeu? É muito melhor. Eu acho que "cê" tem sempre que colocar o ponto positivo de certos assuntos.

Entrevistador: Sim.

Ivani: Se você pensar do lado positivo, que ele vai "tá" aprendendo entre todas as idades, que vai ser dito isso, que vai ser conversado sobre isso, que pode surgir possíveis dúvidas. Em caso que nós vamos, inclusive, falar qualquer coisa, conversar com o pai, com a mãe, com a avó, com tio. Escolher uma pessoa adulta que eu tenho mais intimidade dentro da sua casa pra 
você ser capaz de tirar suas dúvidas. Ou, que vocês venham até tal, tal, tal pessoa dentro da escola pra acabar de tirar suas dúvidas. Ou, sempre vai haver dúvidas, vocês podem confiar no fulano, eles vão te contar as exceções. Falar o todo e deixar uma pessoa aberta. Tem tantos psicólogos nas escolas, gente!

Entrevistador: Sim.

Ivani: Entendeu? Então, assim, coloca uma pessoa pra discutir isso.

Entrevistador: Ou, então, se não tem, convida, né? Faz um cronograma, tipo assim...

Ivani: Convida, faz um cronograma. Quem tiver dúvida, coloca numa caixinha, se "tá" precisando conversar com alguém. Isso não vai tornar público, "cê" não vai precisar fazer essas perguntas na frente dos seus colegas.

Entrevistador: Sim.

Ivani: Entendeu? Por quê? Surgir vai surgir.

Entrevistador: Vai surgir. Agora, me veio uma coisa... (corte/interrupção pela entrevistada).

Ivani: Porque o colega do lado não vai falar "duma" forma legal, né? (risos). Ou vai ser super sacana, ou vai levar pro lado dele, ou vai passar...

Entrevistador: Ou, vai ser irônico pra todo mundo rir na sala e não vai levar a sério, né?

Ivani: É. Aí, vai constranger muita gente de perguntar. Pra quê que valeu aquela aula? Nada. Uma palhaçada, um circo?

Entrevistador: É verdade. Sim.

Ivani: Entendeu? Então, "vão" dar aula? Vamos. Os pais, ó, "Quarta séria primária vai ser falado isso, isso e isso. Quarta série do Ensino Fundamental vai ser falado isso, isso e isso.”.

Entrevistador: E "cê" acha que tem um mínimo de idade pra criança começar a ter essa concepção de sexualidade?

Ivani: Aí, eu não sei a parte clínica, psicológica. Mas, eu acredito que é nove anos de idade, né?

Entrevistador: Aham. Sim, aí tem que ver mais o viés psicológico, né, pra saber.

Ivani: É, eu não saberia. Eu sei que é... no... com nove anos de idade, dez anos de idade, que entra isso nos livros. Se hoje já passou pra oito, pra sete... 
Entrevistador: Não, é, eu acho que é mais ou menos isso, sim. No sentido de conhecer o corpo, né, de ver as diferenças... Acho que é mais ou menos isso, sim.

É... ô, Ivani, agora, assim, o último assunto que tem que entrar aqui é sobre cultura, incentivo à cultura dentro da escola. Por que que cinco aulas de Matemática é mais importante que uma aula de Artes, por exemplo? Que é uma aula por semana.

Ivani: Não é mais importante. Desconsidero isso, até porque eu gostava muito mais de esporte, de ficar dentro da quadra, do que ficar dentro da sala de aula.

Entrevistador: Mas, acho que socialmente, a gente vê que dá muito mais importância pra Matemática e Português, e menos importância pras outras áreas, assim.

Ivani: Sim. Porque são as profissões que eles consideravam - isso é época, né, isso é cíclico. Tanto que antigamente as mulheres bordavam, faziam... Então, assim, isso é cíclico, né? A gente pode ir mudando isso aos poucos.

Entrevistador: Uhum.

Ivani: Hoje, eu vejo a briga do pessoal de Literatura, de não sei o quê, querendo mais horários nas aulas e tudo. Por quê? Porque a Redação se tornou uma coisa importante no ENEM.

Entrevistador: Sim, exato.

Ivani: Né? Então, assim, daqui a pouco a Matemática não é tão importante, acho até que deveria diminuir muito essa quantidade de forma aleatória que vem sendo dada. Mas, é um assunto que, profissionalmente, são as pessoas mais inteligentes, são as que sabem Matemática. Se a cultura ainda é essa, né? A fama ainda é essa, os pais ainda exigem isso.

Entrevistador: Uhum.

Ivani: Não são só os professores que querem dar. Os pais ainda exigem, os filhos ainda querem porque querem ser mais bem sucedidos. Né? Então, assim, a pessoa que faz Artes, tirando alguns mega talentos internacionais, né, não são ricas. Então, você vai querer que seu filho aprenda uma coisa que ele não vai ter dinheiro?

Entrevistador: Sim.

Ivani: É só isso que eles ainda aprendem.

Entrevistador: E a sociedade capitalista, também, coloca a gente nessa posição, né? 
Ivani: É, é só o capitalismo, mesmo, né?

Entrevistador: Aquela coisa da fazer algo por prazer, é melhor que se faça algo por prazer que ganhe dinheiro.

Ivani: Que ganhe dinheiro. Se você conseguir conciliar as duas coisas, aí, você será muito feliz.

Entrevistador: Sendo professor de Matemática "tá" um pouco difícil (risos).

Ivani: É (risos). Entendeu? Mas, as aulas de Matemática, por exemplo, o que a gente escuta é o seguinte: por exemplo, o pessoal da Humanas, se quiser fazer um bom concurso, ele tem muita dificuldade na Matemática. Já uma pessoa da área tecnológica, da área da Matemática, da área das Exatas, se quiser fazer qualquer concurso, ele aprende o Direito rapidinho.

Entrevistador: Uhum, é verdade.

Ivani: Entendeu? Então, assim, parece que tem um QI, tem uma ponta do cérebro melhor do que os demais. Não é de gosto. Olha o que que eles alegam, né? Aquilo não é de gosto, igual pintar; eu não sei pintar nada. Então, pra “mim” pintar deveria ser um mérito exorbitante.

Entrevistador: Sim.

Ivani: Né? Quem pula de não sei quantos metros, que faz não sei o quê, deveria ganhar muito mais do que eu.

Entrevistador: É engraçado pensar que a Matemática, ela rege a vida, assim, né? Porque a gente tem muito mais aula de Matemática no currículo do que todos os outros.

Ivani: Mas, o número de profissões bem sucedidas que ainda dependem da Matemática...

Entrevistador: É muito grande.

Ivani: Ela é muito maior que o número de profissões bem sucedidas que não dependem da Matemática.

Entrevistador: Sim, verdade.

Ivani: Entendeu? Então, por exemplo, se "cê" quer ser um bom economista, um bom não sei o quê, um bom não sei que lá, "cê” depende da Matemática. A parte da Física, "A Matemática está em todo lugar, gente”. Entendeu?

Entrevistador: Sim. 
Ivani: Então, quer dizer... Por isso que a Matemática ainda tem muitas aulas dentro "duma" escola, MAS, não acho que a Matemática dada nas escolas tem valor pra isso.

Entrevistador: Verdade, concordo.

Ivani: A Matemática dada nas escolas não tem esse valor. Pra que as pessoas sejam felizes ou... Entendeu? Ou, que "tá" em todas as profissões.

Entrevistador: Sim, verdade.

Ivani: Não é essa.

Entrevistador: E essa... O governo, ele tinha um projeto, não sei em que pé "tá" o projeto, às vezes, você deve saber até melhor do que eu, de ter um ensino de manhã e de tarde. Esqueci o nome desse projeto...

Ivani: É o integral.

Entrevistador: É, é tipo o ensino integral. "Cê" acha que é uma solução para que se aborde outros tipos de área na parte da tarde? Por exemplo, "cê" tem o ensino regular de manhã; de tarde, quem quer fazer Artes vai estudar mais Artes, quem quer Humanas, vai fazer mais Humanas... É uma solução, né?

Ivani: Eu acho. Eu acho, porque... Não a escola que a gente tem hoje. Não é dobrar a carga horária dos meninos pra fazer...

Entrevistador: Não tem nem merenda.

Ivani: Fazer o que eles fazem na escola, hoje, dobrado, é tortura.

Entrevistador: É tortura. Concordo.

Ivani: Agora, hoje, os meninos... que que acontece: aí, eu vou falar pela classe média. Se você pegar uma comunidade no Rio de Janeiro, ali tem esporte, tem isso; os meninos ficam o dia inteiro nas escolas.

Entrevistador: Sim, ficam.

Ivani: Entendeu? E dali sai bailarinos, dali saem atletas, dali saem jogadores de futebol, dali sai isso, sai aquilo. Na... no... na classe média não sai nada (risos). Na classe média "cê" "tá" é "fudido" (risos). Porque você sai de uma escola, você tem que pagar um inglês, você tem que pagar um curso de Artes, "cê" tem que pagar um violão, "cê" tem que pagar isso. Pra quê pagar isso tudo? Entendeu? Então, se isso existisse enquanto educação... 
Entrevistador: E funcionasse.

Ivani: E primeiros socorros... Qualquer coisa, teatro, quer coisa melhor do que um teatro, do que um esporte, gente?

Entrevistador: Sabe o que uma aluna falou hoje de manhã comigo no João XXIII? Que ela falou assim... é... "Ô, Alexandre, por que que a gente vê logaritmo, que a gente raramente vai usar, a gente só vai usar se a gente for pra uma área de Exatas mesmo, e não vê, por exemplo, - isso aí que 'cê' falou - é... como lidar com uma pessoa que 'tá' passando mal, os primeiros atendimentos". Ela me fez essa pergunta hoje, Ivani, sem brincadeira.

Ivani: Pois é, aí...

Entrevistador: Aí, eu falei, “Olha, eu também não sei, eu acho que 'cês' tinham que ver as outras coisas mesmo".

Ivani: Só que se você, por exemplo, no Colégio Militar que eu estudei, tinha.

Entrevistador: Aí, olha aí, que excelente.

Ivani: Aí, quando os outros falam assim “Colégio Militar é muito bom!”. Aí, os outros não entendem o porquê. Não é que "cê" quer bater continência pra ninguém, não.

Entrevistador: Sim.

Ivani: É porque aquilo era uma delícia, porque você tinha as possibilidades, você tinha quinhentos instrumentos musicais.

Entrevistador: Uhum.

Ivani: E você escolhia fazer.

Entrevistador: Sim.

Ivani: Então, você fazia por gosto. Você tinha todos os esportes, tinha quadras e pista de atletismo...

Entrevistador: Tem uma estrutura pra isso, né? Uma equipe que ensine isso também, né?

Ivani: Entendeu? Então, se as escolas públicas não conseguem fazer isso, mas que tivessem pontos assim pras escolas públicas usarem.

Entrevistador: Sim. 
Ivani: Porque fisicamente, não irão caber dentro das escolas públicas. Mas, se você tivesse pontos na sociedade que você... Tipo assim, uma escola tal aluga isso aqui de manhã de segunda-feira. A escola tal terça à tarde, a outra... você teria, entendeu? Como fazer isso.

Entrevistador: Sim.

Ivani: Logisticamente, não me faça essa pergunta, porque hoje é impossível tudo.

Entrevistador: É. Não, eu concordo.

Ivani: Se fossem bairros, não sei...

Entrevistador: Sim.

Ivani: Entendeu? A gente já pensou algumas coisas.

Entrevistador: E não é só isso, né, Ivani. Eu acho que, assim, o contexto do nosso país não permite fazer isso agora, né?

Ivani: Não permite. Agora, uma mãe que vai trabalhar é... "vamo" falar assim... de manhã até à noite, o filho saindo da escola e ela não sabe aonde é que "tá". Ainda mais que ninguém tem telefone fixo, todo mundo só tem celular.

Entrevistador: Sim.

Ivani: "Cê" consegue falar com um filho? Mas, "cê" nunca vai saber onde que ele está, o que ele está fazendo. Isso é mentira.

Entrevistador: É verdade.

Ivani: Antigamente, "cê" pelo menos ligava pra casa, tinha que "tá" em casa. Hoje, não tem que “tá" em casa. Quer dizer, a sociedade é um depósito de menino? Não, mas “cê” não tem que formar "cidadões"? Cidadãos. (correção pela entrevistada).

Como é que você vai formar se ele não fica nem perto de você? E quando chega, "tá" naquele formato um atrás do outro prestando atenção e comendo logaritmo.

Entrevistador: É.

Ivani: Bháskara e o "cacete". Então, assim, não sou a favor da escola que nós temos em horário integral. Eu sou a favor de uma reformulação e ter... Se você consegue escola pública, que são as escolas militares, com isso, que diminua o número de escola pública que façam 
megas escolas. Que não seja militar, que o nome não seja esse. Mas, não era a mesma coisa? "Cê" num ficava lá o dia inteiro, "cê" não tinha regra, não tinha tudo, senão "cê" saía?

Entrevistador: Toda escola tem regra, né? Todas as escolas têm regra.

Ivani: "Cê" saía, "cê" não conseguia fazer um esporte, "cê" não conseguia fazer o seu balé... Tinha balé clássico dentro do Ciep.

Entrevistador: Sim.

Ivani: Cadê esse formato, então?

Entrevistador: É verdade. Desapareceu.

Ivani: Entendeu? Então, se desapareceu "Ah, não deu certo". Não deu certo por quê? Porque é um gasto muito grande, né? Não dá...

Entrevistador: E o acesso à educação aumentou muito, né, Ivani, assim... Antigamente, poucas pessoas terminavam o Ensino Médio, muitas ficavam até o quarto ano, ali, depois faziam o supletivo. Então, assim, acho que esse crescimento populacional fez crescer muitas escolas sem o aparato necessário pra ter o básico que as escolas têm que ter.

Ivani: Falando de... Pra falar que você é melhor que o outro, meio que unificando as pessoas.

Entrevistador: Sim.

Ivani: Você estuda com poucos, você... Gente, eu moro com o mundo!

Entrevistador: É, sim.

Ivani: Eu vivo com o mundo! Aí, numa escola tem que ter pouquinho? Olha que loucura do ser humano! Onde é que vai chegando. E o pai vai achando bonito. Entendeu? Não interessa que seja o maior marginal da sociedade, podre de rico do seu lado. Mas, são poucos.

Entrevistador: Sim.

Ivani: Então, assim, eu quero uma escola com muitos. Com todas as cores, raças, credos. E o credo? Entendeu? Então, assim, dentro das escolas...

Entrevistador: Porque essa questão de credo é engraçada. Porque, por exemplo, Ensino Religioso, na minha época, eu aprendi Catolicismo.

Ivani: Catolicismo, é. 
Entrevistador: Porque a minha professora era católica. E eu acho que isso influenciou muito, por muito tempo. A pessoa Evangélica ia mais pra um lado, a pessoa de Umbanda ia mais pro outro lado. Só que o Ensino Religioso, na verdade, é você mostrar as religiões que existem no país.

Ivani: Que existem.

Entrevistador: Que existem no mundo.

Ivani: É eclético, o negócio tem que ser de uma forma solta. E até porque o que que a Umbanda acha, o que que Candomblé acha, entendeu? Quais são as referências. É uma história das religiões.

Entrevistador: Sim, é, exato.

Ivani: Entendeu? E cada um segue o que quer. Isso aí é de casa, da educação, sei lá “daonde”. Mas, aprender que existe? Como que as pessoas não podem aprender que existe? Agora, nós temos muito Budismo? Não temos, infelizmente. (risos). Agora, vamos colocar na história lá que existe.

Entrevistador: Sim. Ou, então, "Faz um trabalho aí, gente, sobre todas as religiões do mundo". Aí, cada um faz uma religião... (corte/interrupção pela entrevistada).

Ivani: Cada um faz uma. Como eles se comportam, o que que eles vestem, o que que eles aceitam, o que que eles acreditam. Olha que trabalho lindo!

Entrevistador: É legal, lindo mesmo. Sim.

Ivani: Entendeu? Não, não pode, não pode. Ou, senão, vai puxar sardinha pra um lado. Eu estudei em escola católica, estudei em escola de freira. É lógico que era católica. É a mesma coisa que "cê" colocar seu filho numa escola adventista e não querer que se fale do adventista.

Entrevistador: Não, mas, aí, as pessoas, elas sabem que naquele espaço é isso que rege.

Ivani: É aquilo que rege, entendeu? E esse negócio de... Agora, quando foi mais eclético? Quando eu estava na Escola Militar. Por quê? Porque lá tinha todas... Eu tenho fotos, ali, de dança de Candomblé, e nós todos, a escola vendo e aplaudindo. Quando que eu vi isso em outra escola? Nunca. “Ah, Escola Militar é ruim”. Por quê? Se você "tá” vendo aquilo?

Entrevistador: Sim. 
Ivani: Ai de você que faltasse com respeito a qualquer colega. Independente da cor, raça, credo, opção sexual.

Entrevistador: Sim, é verdade.

Ivani: Entendeu? Você era chamado atenção, atenção mesmo, "cê" era suspenso. Você tinha uma punição pela falta de respeito, não era... não era preconceito com nada, não.

Entrevistador: Era respeitar tudo e todos, né?

Ivani: E todos, e era obrigatório. "Cê" não tinha outra chance. Então, se eu tinha todos os esportes, tinha coral, tinha música, tinha... Tinha tudo, gente. Tinha tudo. Primeiros socorros, todos os bonecos - te mostro foto- todos os bonecos deitados, os outros aprendendo não sei o quê, não sei que lá. Tinha laboratórios e laboratórios de Física, de Química, de tudo. "Cê" tinha acesso, "cê" ia pra profissão e pro lado que você tivesse dom. Agora não, "cê" tem que ir pra onde? Que que leva uma criança descobrir algo diferente pra sequer querer alguma outra coisa? Nada.

Entrevistador: Sim.

Ivani: Nada. Ele não foi apresentado a nada. Que que uma escola apresenta "prum" jovem?

Entrevistador: Uhum.

Ivani: NADA! "Cê”’ sabe que que é nada? É nada. Hoje, o que eu vejo dentro das escolas não precisa ser pública, não, particular, também - é uma apresentação do nada.

Entrevistador: É, são raras as escolas que têm esse misto de coisas que despertam interesse nos alunos.

Ivani: Não vai ter tudo. Lógico que não vai ter tudo. Tanto que aí, depois, dentro de uma grandeza, você falar assim: "Não, eu gosto mais daquela escola, porque lá dá muito mais música, lá tem muito mais show, né, tem muito mais coisa.". Ou, "Eu gosto da escola tal porque tem muito mais esporte".

Entrevistador: Uhum.

Ivani: Quem dera você escolher uma escola por isso, né?

Entrevistador: Sim. Hoje em dia não tem mais isso, não. 
Ivani: Tem muito mais dança, tem muito... né? "Cê" escolhe escola por nada. Como que "cê" escolhe uma escola? Se você tivesse que colocar o filho, hoje, numa escola, qual critério que "cê" usaria? Nenhum. A não ser que o meu vizinho falou que era melhor, ou lá é mais caro...

Entrevistador: Status, né?

Ivani: Ou, lá estuda o filho do prefeito e do médico tal, do doutor fulano. Então, é lá que a minha filha vai estudar, seu critério é esse. É podre, é fraco.

(Barulho no ambiente).

Entrevistador: Achei que era chuva de novo.

Ivani, agora pra terminar mesmo, até porque eu queria te agradecer pela entrevista, foi ótima! É... esse projeto, acho que... é, realmente, pra gente conversar sobre essas coisas, porque o que que eu percebi na faculdade: todo mundo é diferente, todo mundo pensa diferente. E todos os diferentes vão entrar numa sala de aula. Então, eu acho que a gente tem que chegar num consenso de como abordar os assuntos que vão surgir. Porque enquanto um fala assim "Ah, eu acho que não é assim que funciona", o outro fala assim "Não, mas eu acho que é". Então, o menino que pega o que acha que é, é diferente a realidade dele, como ele vai se desenvolver dentro da escola, que se ele pega um cara que acha que não tem que falar sobre vários assuntos. Então, assim, eu acho que é válido e eu queria saber de você se você também acha que é válido a gente conversar sobre essas coisas.

Ivani: Qualquer assunto eu acho válido conversar.

Entrevistador: Dentro do... do contexto de Matemática, de escola, e não simplesmente "Ah, não concordo com a sua posição política, então, nem vou olhar na sua cara”. Sabe? Assim...

Ivani: Eu acho falho, acho pobre - da mesma forma que eu acho as escolas onde você não tem como colocar um filho pela pobreza, hoje, que elas estão - é... eu acho pobre é você não poder conversar e participar de qualquer assunto independente do quanto você viveu sobre aquele assunto. Então, por exemplo, se for falar de aborto, existem pessoas que fizeram aborto de certas formas, outras de outras formas, algumas de umas religiões, outras, de outras religiões. Uns eram pais que não tiveram nem poder de opção; outros são os pais que exigiram e quiseram. Então, qualquer assunto, eu acho que ele é social.

Entrevistador: Sim. 
Ivani: Esse negócio, assim, "Só pode falar quem passou e quem viveu”. Só pode falar quem passou e quem viveu pra dar o depoimento do que passou e do que viveu, mas, o assunto é público. O assunto é um problema social.

Os remédios são uma droga. "Vão" falar dos remédios que são uma droga? Isso é um problema social. "Mas eu nunca tomei esse, eu não sei qual que é esse". Não existe isso. Entendeu? “Ah, eu não vou falar sobre racismo?”. Não, eu tenho que estar num debate com preto, branco, amarelo, roxo, abóbora. Eu tenho que estar num debate de racismo. Eu acho que parece que as pessoas querem ficar entre elas pra ganhar força. E quando elas estão publicamente, elas têm medo de ganhar conhecimento.

Entrevistador: Sim.

Ivani: Elas têm medo de descobrir que, às vezes, aquela não é a verdade absoluta. Essa clausura é colocada muito socialmente, hoje. Eu queria sentar e discutir sobre Umbanda e posso nunca ter ido a um centro de Umbanda.

Entrevistador: Sim.

Ivani: Qual o problema de eu ver uma discussão dessa? Ou, colocar uma opinião bíblica em cima daquilo?

Entrevistador: Por que que tem que ser isso OU isso? Não E, né?

Ivani: Só pode discutir e falar sobre? Não...

Entrevistador: Quem já viveu.

Ivani: Quem já viveu. Eu vou morrer sem saber isso, sem entender isso. Eu posso nunca ter vivido, mas eu tenho curiosidade.

Entrevistador: Sim.

Ivani: Eu posso perguntar, eu posso dar uma opinião contrária, baseada em alguma coisa que eu conheço e que eu "tô" vendo que ali é o oposto. Eu posso falar... é... espiritualmente de uma pessoa que fez um aborto sem eu nunca ter feito, e ela achar completamente diferente de $\operatorname{mim}$.

Entrevistador: Verdade, sim.

Ivani: Qual o medo? De falar "É minha culpa, minha grande culpa"? Um aumento das religiões... Qual o problema "deu” falar do aumento das religiões? “Ah, mas eu sempre fui 
católico apostólico romano, eu não vou falar de aumento de religião nenhuma". "Cể não notou que a sua igreja esvaziou?"

Entrevistador: Verdade. E “tá” acontecendo muito isso.

Ivani: Ou, não notou um movimento católico completamente diferente pra tentar não perder ou pra tentar ganhar?

Entrevistador: Sim.

Ivani: Qual o problema de "cê" saber que, de repente, seu pastor falou com você um "trem" que não "tá" escrito em lugar nenhum na bíblia?

Entrevistador: Se contestar, né, tipo assim...

Ivani: "Cê" contestar a religião pensada, sem ser dogmática, em qualquer assunto social?

Entrevistador: Sim, exatamente, sim.

Ivani: Gente, eu sou diferente de tantas pessoas nesse mundo. Mas é milhares, entendeu? E adoro conversar e nunca briguei com ninguém por causa disso, não. Quem quiser que ataque, mas, eu, brigar com uma pessoa porque ela pensa diferente?

Entrevistador: Sim. Mas, o intuito desse projeto, Ivani, que o Marco Aurélio até gostou muito, tanto é que até aceitou orientar - o primeiro que a gente "tá" fazendo na Matemática sobre esses assuntos - é justamente isso: a gente não vai lá só pra dar disciplina. Então, a gente tem que saber falar sobre as coisas e conversar, mesmo que um concorde e um discorde. Porque, senão, a cabeça desse menino lá dentro da escola fica como? Se um fala o que tem que falar e outro fala o que não tem que falar? Então, assim, eu não sei se "cê" entendeu bem o projeto, mas, é mais isso; eu "tô" coletando entrevistas de diversos pontos diferentes e eu vou falar "Gente, os professores são diferentes". Que que a gente vai fazer com isso?

Ivani: Os alunos são diferentes, as famílias são diferentes, os professores são diferentes. Eles podem até querer... quem... esse pai que, por exemplo, que não concorda e não aceita que seja dado determinados assuntos, "vão" chamar, "vão" dar uma aula pra ele do que vai ser dito?

Entrevistador: Sim, quem sabe ele não desconstrói o mundo na cabeça dele, né?

Ivani: Não é nem mudar a opinião dele, mas ele aceitar...

Entrevistador: Não, sobre abordar o assunto. 
Ivani: É melhor que seu filho aprenda de uma forma, de um adulto responsável falando, com respaldo clínico, ético, moral, sei lá quantos - o que o cara quiser escutar, do ouvido que ele escuta - do que pelo coleguinha, no meio da rua, indo pra casa só os dois. Que o senhor vai falar assim: "Da casa ele vai pro colégio, do colégio ele vai pra casa, o senhor sabe o que que eles conversam no meio do caminho? 'Cê' sabe o que é dito dentro da sala de aula?".

Entrevistador: Sim.

Ivani: "Se o senhor não sabe o que que é dito, deixa alguém da confiança do senhor tentar, pelo menos, dizer a ele o que 'tá' se passando".

Entrevistador: Sim.

Ivani: "Ou, se o senhor acha que tem que casar virgem depois de 30 anos de idade, me dá um respaldo pra eu conversar com seu filho, pra dizer o que que existe sobre isso". "Eu não posso deixar seu filho solto aqui dentro, jogado aqui dentro."

Entrevistador: Uhum.

Ivani: É uma conscientização mesmo, assim, social, sabe? Eu não sei se daria certo, como que iria fazer, de que forma iria fazer. Não sei, nunca parei pra pensar isso; em escolas menores, maiores, as concepções sociais e tudo. Não sei como fazer, mas deixar um aluno solto, ou fora, ou dentro de um assunto simplesmente porque TEM que ser assim... É violento, né?

Entrevistador: É, é verdade.

Ivani: Aí, vem suicídio... Vem estresses....

Entrevistador: Vem aluno que entra na escola e sai atirando nos outros...

Ivani: Olha a quantidade de remédio que esses meninos "tão" tomando, Alexandre.

Entrevistador: É verdade. Muito.

Ivani: Isso é mais droga do que muita droga na vida junto.

Entrevistador: Sim.

Ivani: Isso é crime, gente.

Entrevistador: E quando não conversa aluno, escola e família, gera isso tudo, né? Depressão, ansiedade... 
Ivani: E qual valor que é pra ser dado a cada assunto?

Entrevistador: Sim.

Ivani: Por que que tem que ter um glamour social pra tantos assuntos que, às vezes, poderia ser em outra época, de outra forma, de uma forma mais natural?

Entrevistador: Sim.

Ivani: Não é que eles não venham, entendeu? Por que também valorizar "taaaanto" umas coisas, às vezes, tão pejorativas pra sociedade, tão ruins?

Entrevistador: Sim.

Ivani: Entendeu? "Ah, 'vamo' jogar pedra na cruz, agora virou moda. 'Hahaha', é pedra na cruz, é pedra na cruz". Aí, "cê" entra é pedra na cruz, "cê" sai dali é pedra na cruz, e o assunto vira só esse?

Entrevistador: É.

Ivani: Um modismo, gente. Que que isso? "Vamo" falar sobre modismo.

Entrevistador: Hoje em dia "tá" tudo muito explosivo, assim, né? Ainda mais com rede social que todo mundo fica sabendo tudo que "tá" acontecendo.

Ivani: É, e como combater isso de uma forma assim, "Ô, gente, isso é moda, isso é o quê? 'Vão' trabalhar isso". É um assunto, assim...

Entrevistador: Muito relevante?

Ivani: Muito relevante? Pouco relevante? É todo mundo que "tá" saindo por aí jogando pedra na cruz? Então, "vamo" dar menos valor, "vamo" ver que essa pessoa, às vezes, não "tá" equilibrada, e vamos, nós, colocar a gente pra pensar, pra, né, pra tentar ponderar, ver as necessidades. Eu acho que tem que botar muita gente na real, também, né?

Entrevistador: Com certeza.

Ivani: Parece que "tá” vivendo num mundo...

Entrevistador: É, o toque.

Ivani: Então, assim, não sou dona da razão, em hipótese nenhuma, "tô" falando pela experiência de vida que, no mínimo, tem que ser respeitada pela idade.

Entrevistador: Sim. 
Ivani: Entendeu? Assim, qualquer... Não como vivência, porque eu vou aprender com um menino de cinco anos de idade sentado no meio fio na rua.

Entrevistador: É, mas o que você viveu também tem um respaldo, né?

Ivani: E tem um pouco, pelo menos, visão social a mais de muitos homens e outras pessoas.

Entrevistador: É verdade.

Ivani: Só. Isso merece respeito, querendo ou não. "Cê" entendeu? Como qualquer pessoa merece. E as pessoas, às vezes, não entendem. E a forma, tipo assim, “É porque eu já passei da idade, da cor e do peso" pra ser agredido, entendeu? Religiosamente falando, caguei e andei (risos). Mas, isso é feio.

Entrevistador: Sim.

Ivani: Sabe? As pessoas, o tempo inteiro, elas querem te provar.

Entrevistador: Ter razão em cima de você.

Ivani: Ter razão. Não é ser feliz, não. Ter razão. O negócio é ter razão. "Eu 'tô' certo". Ah, vai com a sua razão, com a sua certeza, eu vou com a minha razão e com a minha certeza, e vou seguir a vida, mas pode cumprimentar, pode abraçar, pode rir.

Entrevistador: Pode conversar, pode discordar.

Ivani: Posso precisar de você e você de mim.

Entrevistador: Sim, exato.

Ivani: Olha, "daonde" que as pessoas estão tirando que não podem, né?

Entrevistador: É puxado...

Ivani: Eu acabo, pessoalmente - agora, vou falar pessoalmente - matando, parece que matando, alguns preconceitos e alguns conceitos com a minha forma de ser. Entendeu? Porque eu entro em ambientes, assim, onde as pessoas faltam muito com respeito, e me veem respeitando; então elas, tipo assim: "Ela que pensa diferente de mim consegue ter muito mais respeito e educação". Aí, a pessoa meio que "Uai, será que eu sou tão certo assim?". Eu acho que eu questiono algumas pessoas por dentro, entendeu? Mas, não... É por simplicidade, ou por caridade, ou por atenção, ou por olhar, ou por mão na mão, ou por solidariedade, ou por qualquer coisa. Porque, aí, é individual e no que a pessoa acredita, né? 
Entrevistador: Sim. Ótimo.

Ivani: E deixa as pessoas seguirem do jeito que elas quiserem. Nunca eu vou deixar de ter as pessoas ao meu lado por elas pensarem o que quiserem pensar.

Entrevistador: Sim. Ivani, muito obrigado, foi muito produtivo, muito bom. Quero agradecer seu tempo e... é isso. Espero que você tenha gostado do bate papo.

\section{ENTREVISTA 3}

Entrevistador: Primeiro, Marcelo, a gente vai falar sobre racismo. Quando você escuta sobre racismo, o que você pensa sobre esse assunto?

Marcelo: Bom, uma coisa que eu percebo muito é que se fala - hoje, assim, atualmente -se fala muito do feminismo, se fala muito... - não tanto quanto feminismo, a questão da LGBTfobia - mas, ainda é muito tabu se falar sobre racismo. É muito tabu, ainda é muito mal visto; quem fala, quem se posiciona. E é uma coisa que é recorrente, assim, "tá" no imaginário brasileiro. E, assim, as pessoas acham que são casos isolados, mas não são casos isolados. É uma coisa constante, é uma coisa que, tipo assim, você foi criado numa sociedade racista, você é automaticamente racista, do mesmo jeito que você é LGBTfóbico e, também, machista. Você foi criado na sociedade, você é. Então, tem que haver um esforço pessoal de desconstrução. Em todos esses aspectos. E eu, pessoalmente, assim, a minha desconstrução, ela veio muito por conta do meu cabelo. E, aí, foi quando eu comecei a me entender - porque também acontece isso, às vezes, a gente não se entende como indivíduo preto - a gente demora quando a gente não é retinto, quando a gente é mais claro. Então, às vezes, a gente demora a se colocar nessa posição de sempre perceber... Eu sempre percebi as diferenças de tratamento, as atitudes, às vezes, as agressões que aconteceram. Mas, é uma coisa que é um processo, e foi um momento que eu consegui me entender como um indivíduo preto.

Entrevistador: Achei massa a gente começar sobre esse assunto, porque você milita, né? Dentro da Matemática, você militou muito sobre esse assunto, né?

Ô, Marcelo, no nosso país, como que esse assunto é tratado? Como o racismo é tratado?

Marcelo: Como eu "tava" falando, é uma coisa que ainda é bem difícil de falar. É bem difícil, assim. Eu vejo... No meu local de trabalho, eu já vi situações; já vi situações em sala de aula, 
muitas situações - tanto comigo, quanto com outras pessoas - e é isso, assim. Até, por exemplo, motorista de Uber. Qualquer lugar, em qualquer momento. Como é uma sociedade extremamente racista, então, é mais fácil você encontrar... a probabilidade de você encontrar um racista no meio da rua é muito grande. Então, é algo como uma subjetividade coletiva que paira, né, a partir de uma cultura que foi construindo essa ideia. Então, é por aí...

Entrevistador: E nas escolas, como você acha que é esse tema, assim?

Marcelo: Então, há muita evasão, né, assim, eu já percebi - pelo menos, assim, pelas coisas que eu já li e tals - uma grande evasão, principalmente, de sujeitos pretos. E, assim, acho que vale ressaltar a questão de eu estar falando "sujeitos pretos", não "negro", porque, assim, a partir das literaturas que eu busquei e tals, eu descobri que a origem da palavra negro, assim... Existem duas possibilidades: ou a gente desconstrói, ou a gente muda o significado da palavra. Em vários lugares, essa palavra... Porque teve uma mesma origem e é, basicamente, pra poder denominar um ser humano inferior. E não há muito... Tanto que, assim, todo contexto que a gente usa negro, não é um contexto positivo. Nós somos a mesma espécie. Não existe esse negócio de raça, né, nós somos a mesma espécie. Eu até "tava” pesquisando sobre evolução humana, e a gente é uma das espécies mais irmãs que existe, porque a gente teve um gargalo - acho que foi a partir do Homo Erectus, se eu não me engano - que restaram dez mil indivíduos e, a partir daqueles dez mil indivíduos, é que foram havendo as combinações de DNA e genética que... é... origem de todos os indivíduos que existem hoje. Então, assim, nós somos espécies, somos da mesma espécie, então, não faz sentido essa... No máximo cor mesmo, nós temos cores diferentes. E, em alguns lugares, é até proibido essa terminação. Mas, assim, eu tento... É que a gente tem vários termos pra aprender, a gente vai aprendendo até de cada parte, porque a gente vê que o preconceito, ele vai se disseminando em várias vertentes, né? Não é só... não é racial, não é só sexual ou de gênero, não é só... - vai se disseminando - de etnia, de origem, de lugar onde "cê" vive. Então, é muito válido sempre procurar aprender.

Entrevistador: Sim. "Cê” já falou que presenciou e já viveu racismo, até relacionado ao seu cabelo, né?

Marcelo: Sim, também constante. Já é um lugar, é uma caixinha que sempre te colocam. Não tinham serviços de cabeleireiro, por exemplo, que entendessem de cabelos crespos e cacheados. Não tinham, eles não sabiam mexer com isso, e o que que eles faziam? Alisavam, porque eles sabiam mexer no cabelo liso. Sabe mexer com cabelo liso. Não existiam lugares 
que... Hoje, começou um movimento pra isso, "tá" tendo muito mais coisas voltadas pra isso, porque, agora, existe um comércio, existe uma demanda, né? Até o governo Lula, inclusive, que abriu bastante e... Existe essa demanda, porque muitos conseguiram entrar na faculdade, conseguiram... Então, existe essa demanda por conta disso.

Entrevistador: "Cê” está trabalhando em alguma escola, Marcelo, atualmente?

Marcelo: Não, não trabalho. Mas, assim, de experiência de escola, eu já tive estágios e bolsas. E, também, já vi preconceitos com alunos...

E é interessante, porque é uma construção social, então, é muito...

Entrevistador: Dentro do estágio?

Marcelo: Sim, sim, eu vi, eu vi com uma aluna, especificamente. Saiu chorando... Relacionado, também, ao cabelo. Comigo também, "Seu cabelo não mexe.". Porque, assim, a gente alisa, né? Eu nem conhecia meu cabelo virgem durante muito tempo. Desde muito nova que eu alisava o cabelo. E, né? As piadinhas, as perguntas; e, por exemplo, as pessoas, elas não têm problema em tocar, em... é... lidar constantemente com você, porque você... Não tem ninguém pra te defender; ““foda-se', é só um sujeito preto.”. Então, as pessoas... Tanto que rolou, também, no meu local de trabalho, uma colega que todo dia de manhã vinha e dava uma "afofada" no meu cabelo (risos). Todo dia de manhã ela vinha no meu cabelo. Ela não fazia isso com mais ninguém, ela fazia comigo. Aí, chegou um ponto que eu tive que falar: "Poxa, então, não tenho essa intimidade com você, não te dei essa intimidade". E, assim, na rua, lugares que "Ai, que bonito!", e vai pegando. E, também, na própria faculdade já aconteceu de professor falar assim: “Ah, então, depois vou te contar porque que eu não gostei do seu cabelo".

\section{Entrevistador: Sério?}

Marcelo: Sério! Sério. Entre outros, assim...

Quando eu era mais novo, também - quando eu era bem mais novo - também rolou agressão por parte da família, porque a minha família por parte de mãe, ela é branca. A maioria é branca. E, por parte de pai, tem negro, tem índio. Acho que até tem, na minha família por parte de mãe, negros, porque tem algumas características. Mas, assim, toda a história... Essas pessoas, esses indivíduos, eles foram apagados. Não existe uma história, assim, que eu possa, sei lá, fazer uma árvore genealógica, porque fica... Não tem como. 
Entrevistador: Marcelo, você fez Matemática, Licenciatura. Você acha que o professor de Matemática tem que falar sobre racismo?

Marcelo: Não necessariamente, talvez, falar sobre racismo. Talvez, como o momento pede, eu acho que é fundamental que se fale. Mas, pensando, assim, numa sociedade que já superou isso, eu acho que o ideal seria, simplesmente, sempre contextualizar momentos históricos, contextualizar dados, sabe? Contextualizar as coisas e discutir, abrir sempre discussão sobre isso.

Entrevistador: Trazer representatividade.

Marcelo: Isso. Representatividade também, lógico. Porque é, desde novo, assim, as pessoas que eu conhecia, negras - pretas - elas não estavam em lugares de destaque, em lugares de... em posições sempre subservientes. Inclusive, hoje, em palestras, em congressos, em lugares que eu vou, a grande parte da população preta "tá" servindo. Então...

Entrevistador: Se um aluno sofre racismo, assim... Agora, uma hipótese. "Cê" acha que esse tipo de coisa pode influenciar positivamente ou negativamente o aprendizado da Matemática com esses alunos?

Marcelo: Com certeza, o aprendizado, em geral. Da Matemática mais ainda, porque a Matemática é uma ciência elitista, é uma ciência elitista, então... E, assim, se você vê os dados, você vê que a grande parte da população pobre, ela é preta. Então, é uma ciência elitista e é dada por pessoas que têm uma concepção, também, muito racista; então, é complicado. Não é geral - encontrei muitas pessoas muito boas, acho que tive muita sorte, também, na vida, de encontrar muitas pessoas que me deram muita força - acho que só concluí, também, porque existiam essas pessoas na minha vida. E, com certeza, com certeza influencia. Como até o Marco Aurélio falou, ninguém aprende quando "tá" triste, ninguém aprende quando "tá" depressivo, ninguém aprende ansioso, ninguém aprende quando não se sente minimamente à vontade no ambiente que "tá". E, a maioria, assim - em questão de escola - essa evasão acontece porque as pessoas se sentem... Sabe? Elas são agredidas, não são compreendidas, não têm fala, não têm voz. Os professores não conhecem seus alunos. Então, hoje, a escola acaba sendo um ponto de interrogação: "Por que eu vou pra escola se eu vou passar por isso?".

Entrevistador: Tranquila essa parte? Podemos passar para outro tema?

Marcelo: Sim! 
Entrevistador: Gênero e sexualidade têm que ser falado na escola?

Marcelo: Com certeza, com certeza. Com certeza e, assim, com as denominações que "tão" sendo usadas e... E é interessante, de fato, porque nós não somos... O ser humano é muito complexo, ele é muito complexo, sabe? E muito plural. E ninguém cabe nas caixinhas que sempre nos deram de ser homem, de ser mulher, de família, de... Ninguém cabe nessas caixinhas, sabe? E, aí, tentam constantemente aparar as arestas pra que você encaixe naquele lugar. Isso não existe. E, hoje, a gente sabe que, na ciência, a diversidade é fundamental; é fundamental pra pensamentos diferentes, visões diferentes, experiências diferentes que enriquecem muito. Pesquisas e, né? Todo o conhecimento científico. É fundamental a diversidade. Então, sim, com certeza.

Entrevistador: Mas, falar sobre sexualidade não é ensinar os alunos a fazerem sexo? (risos). Marcelo: Risos do entrevistado.

Só que não! (risos). Só que não, né? Porque é uma coisa bem diferente, o fazer, né, o ato sexual, da sexualidade. E a sexualidade, ela abarca a questão do corpo, do conhecimento do seu próprio corpo e, também, de saber se defender, de saber o que que pode e o que que não pode, sabe? A gente vê, aí, também, por exemplo, quantas crianças... Então, casos de abuso que são denunciados justamente porque a criança não sabe o que que... E é aquela coisa, gente, criança não é de pai e de mãe, não é de família. Criança não é... Criança é do mundo, somos seres do mundo, sabe? A gente tem que ser criado pro mundo. E muitos valores familiares, muitas vezes, estão completamente deturpados e errados, e isso afeta toda uma sociedade. Então, é muito fundamental, também, falar de gênero e sexualidade.

Entrevistador: E com que idade você acha que pode começar a falar sobre esse assunto?

Marcelo: Então, eu não sou especialista, mas, pelo que eu já pesquisei, é por volta dos seis anos, quando começa a desenvolver a questão de se tocar, de se conhecer, de saber algumas coisas básicas. Então, acho que é mais ou menos isso, pelo que eu pesquisei, uns seis anos.

Entrevistador: Se você é professora de Matemática, e você vê uma criança que está com uma tendência transgênero, por exemplo, quais seriam as atitudes?

Marcelo: Bom, inicialmente, eu vou recomendar pros pais "procurar" um psicólogo. 
Entrevistador: Vamos supor que você seja a primeira pessoa a perceber isso. Ou, então, a própria criança chegou a se abrir com você, falar que é menino, mas se identifica com "coisas de menina", está começando a não se identificar com seu próprio corpo... O que você faria?

Marcelo: Bom, com certeza, não julgamentos. Julgamento é um negócio que ninguém merece, né? De nada. A gente não tem poder sobre a vida do outro. Então, é... E, também, a questão de acompanhamento psicológico, porque, assim, se eu falar no tempo de hoje, no tempo atual, acho que é fundamental um acompanhamento psicológico, porque a sociedade "tá" doente e aquele ser humano vai ter que viver numa sociedade doente. Então, vai precisar de um acompanhamento psicológico. E até, também, porque... Pra poder se conhecer, de saber se é aquilo mesmo, se entender como, né? Então, assim, não tenho tantos conhecimentos também pra poder falar sobre, mas, o que eu também já conheço e tal, seria um acompanhamento psicológico. Mas também, né, tem que acolher, tem que acolher da melhor forma que "cê" puder e tals; e, também, eu acho que, como professora de Matemática, eu acho que eu ia trazer essas questões pra sala de aula, sabe? Tentar trazer alguns dados, algumas assim, sabe? Abordar esse tipo de coisa, porque tem um aluno, ali, que precisa ouvir certas coisas, saber que existe.

Entrevistador: Seriam atividades voltadas para a estatística, né?

Marcelo: Isso. Isso, com certeza.

Entrevistador: Marcelo, feminismo. Como que ele influencia na escola, nos direitos que as mulheres têm hoje? Tem que falar ou não tem que falar? Tem representatividade?

Marcelo: Então, hoje, eu acho que o movimento feminista é muito forte. Do mesmo jeito que eu acho que em alguns momentos históricos também foram muito fortes, mas, não foram televisionados, não foram levados pra história, assim, e mostrado, mas, o movimento feminino "tá" muito forte. Muito forte, muito forte. E há que se falar, porque são coisas que também são constantes, sabe? São constantes na sociedade - é uma coisa cultural, também - e, por exemplo, coisas básicas, coisas simples, e que... Inclusive, mulheres, sabe? Elas corroboram, criam esse ciclo, ainda, de continuar tentando... A gente tenta se encaixar, porque “Ah, não posso sair muito, não posso...", assim, sabe? Eu continuo tendo que seguir algumas regras sociais pra poder... E, por exemplo, eu acho que eu saí do departamento da Computação por conta disso. Foi muito mais isso do que qualquer outro tipo de... Foi muito isso, porque “Mulher não sabe programar”. Né? Assim, essa é a máxima. 
Entrevistador: Você ouviu essa frase?

Marcelo: É. E, também, de atitudes. Atitudes, assim, como, por exemplo, se vai separar um grupo, a mulher fica com a parte de visual da coisa. Não... né? A parte grossa, a parte... A gente sempre tratada como enfeite. Então, assim, não é legal. Não é nem um pouquinho legal. Só que "tá" forte esse movimento e eu acho, assim... - eu tenho muita esperança mais nas mulheres do que... (risos).

E, assim, por exemplo, eu vi um documentário, também, chamado "Espero a tua revolta", que fala sobre as ocupações das escolas. E, assim, foi um movimento, também, muito feminista. Foi um movimento assim... Tanto que em algum momento do vídeo fala assim... Tem um narrador, um homem que narra durante um bom tempo. Aí, de repente, fala assim: "Então, mas, assim, a maioria que movimentou foi uma mulher, foram mulheres, então...”. Aí, tipo assim, "Dá licença que agora as mulheres vão falar". Então, eu tenho muita fé, muita fé nas mulheres, nesse aspecto. Apesar de que, também, rola muito machismo, inclusive, de mulher com mulher. "Ah, celulite!”, “Ah, não pode usar certa roupa!”, “Ah, não pode fazer isso!", “Ah, a gente tem que se encaixar naquele lugar.”. E, como eu falei inicialmente, o ser humano é muito plural, inclusive, mulheres e homens. Generalizações, em sua maioria, são burras, são... sabe? Não dá pra encaixar, não dá pra criar um padrão, senão, não cabe todo mundo.

Entrevistador: Você sofreu machismo na Matemática? $\mathrm{Na}$ área da Matemática, especificamente?

Marcelo: Eu acho que também rolou uma certa condescendência, acho que isso é clássico. É uma condescendência, um paternalismo de, tipo assim, "Você não é capaz o suficiente", sabe? Você não... "Ah, não foi você que fez isso", sabe? Umas coisas, assim, meio complicadas nesse aspecto. Mas, eu acho que isso é muito mais - como eu vou dizer? - uma coisa... Rolou muito na Computação, na Matemática, nem tanto. Acho que na Matemática foi um pouco mais tranquilo. Mas...

Entrevistador: Sentiu isso mais na Computação, né?

Marcelo: Na Computação. Na Computação. Na Matemática rolou o lance do racismo, o racismo rolou. Agora, na Computação foi mais o machismo. E são os dois lugares de fala que eu tenho, mais, assim, de... né? Da pele que habito (risos). 
Entrevistador: Você acha importante, nas escolas, já mostrar pras mulheres que elas ainda não têm os mesmos direitos? Que existe uma diferença muito grande salarial...

Marcelo: Salarial, representatividade, por exemplo, em cargos de poder, né?

Sim, com certeza tem que ser mostrado, tem que ser dito, tem que ser debatido. E, assim, eu também vejo muito que essas próximas gerações, aí, também "tão" vindo bem afiadas, assim, pelo menos o que eu vejo. Eu não tenho muita noção, mas, desde o que tem acontecido, aí, politicamente e tals, tenho visto muita militância, principalmente, nos jovens.

Entrevistador: Agora, Marcelo, Bullying. A Andreza, num vídeo, sabe... Ela falou que Bullying é besteira...

Terceira pessoa: Não era a Andreza! (risos de várias pessoas no ambiente).

Entrevistador: A gente fez um teaser, eu te mostrei o teaser? Não lembro se eu te mostrei...

Marcelo: Não, acho que não...

Entrevistador: Depois te mostro. Aí, a Andreza foi a “Ah, não, Bullying é besteira!”.

Mas, vamos falar sobre Bullying.

Marcelo: É muito complicado, porque assim: depende, também, acho que muito da... da etapa. Porque, assim, crianças, elas podem ser muito cruéis. Naturalmente, muito cruéis. Já também aconteceu comigo, por exemplo, em escola de um aluno que tentou me beijar à força. Então, assim... E Bullying constante. Só que é muito complicado, porque tem que ter um direcionamento, mas também, tem que tomar muito cuidado pra que não haja um silenciamento, sabe? Porque, muitas vezes, a pessoa que pratica o Bullying também tem muitos problemas em casa, de agressividade... Porque se a criança ou o adolescente "tá" se posicionando daquela forma, é porque é aquela linguagem que ele conhece. Então, assim, é muito complicado.

Entrevistador: É a forma de ele expressar uma coisa que ele não "tá” sabendo lidar, né?

Marcelo: É, e o papel do professor é ser o mediador nessas situações. Tem que ter a representatividade, tem que abordar esses assuntos e contextualizar, mas, essas questões de conflito, elas são muito complicadas, porque tem que haver uma mediação e tem que ser tratado tanto quem "tá" sofrendo o Bullying, mas também, quem "tá" fazendo o Bullying, de uma forma muito cuidadosa. Assim, eu, particularmente, assim, não tenho muito conhecimento. Assim, o que eu já estudei - e que eu acho muito interessante - é a pedagogia 
positi... não, criação positiva? Não lembro exatamente o nome, mas, voltado mais pra afetividade, pra, né, pra uma criação mais amena.

Entrevistador: O professor de Matemática, ele ajuda uma pessoa ou não? Direciona essa pessoa para um tratamento especializado? Às vezes, até na escola, né, tipo, projeção, encaminhar pra um psicólogo e tal. Porque ele só “tá” preocupado em passar matéria, ele não faz isso, você acha que pode corroborar pra que aconteçam coisas piores?

Marcelo: Sim, sim, é aquela tal coisa: o não posicionamento é um posicionamento. Você não se posicionar é um posicionamento. Se você... É que nem aquela história da bola: se você vê uma bola descendo o morro - as crianças "tão" lá brincando - vê a bola descendo o morro e você não para a bola, você teve um posicionamento ali; você teve um posicionamento, não tem como. Então, é fundamental, eu acho que... se tratar disso, falar sobre isso. É fundamental. Acho que eu não vejo um futuro melhor - até, inclusive, pra educação - sem isso.

Entrevistador: Acho que "tá” ok esse assunto, também, né? Senão, a gente começa a repetir, né?

Entrevistador: Então, segunda parte. Agora, a gente vai falar sobre a comunidade LGBT+. O que "cê" conhece sobre esse assunto, Marcelo?

Marcelo: Tenho me inteirado o máximo que eu posso. Porque assim: um, que eu "tô" cercada de pessoas lindas e maravilhosas que são, que fazem parte desse grupo, e que fizeram parte da minha história constantemente - que, aliás, também, são pessoas que, né, foram fundamentais na minha formação. Acho que não sei tanto quanto eu gostaria, mas - digamos assim - eu já "tô" aprendendo muitos termos em questão... é... diferenciando gênero de sexualidade, nomes e, tipo, algumas questões específicas. Mas, assim... Como não é a minha pele, eu... é muito mais difícil de falar, sabe? Eu sempre procuro dar o lugar de fala pra quem...

Entrevistador: Aprender com quem sabe.

Marcelo: Isso, isso. Já aconteceu, por exemplo - porque, assim, é que nem eu falei: se a gente nasce numa sociedade que é, a gente naturalmente é, a gente tem que fazer um esforço pra deixar de ser. E, assim, já aconteceu, por exemplo, de, algum momento, eu usar a palavra "viado" como uma coisa pejorativa. E já aconteceu de amigos meus falarem e me chamarem a atenção. "Tá" certíssimo, certíssimo. Eu sou... Eu procuro ficar sempre atento e aberto a essas questões. E uma coisa, também, que eu estudei recentemente sobre - gosto muito da parte da 
Biologia, a parte da evolução - que eu descobri, por exemplo, que existem os traços genéticos específicos dessas... - que não é uma escolha, né? - dessas variabilidades. E... e, também, existe a parte externa - que também é formado pela parte externa. Mas, a gente acha que é social, mas não é, necessariamente, social, porque grande parte dessa mudança, ela acontece dentro da barriga da mãe. Então, assim, é externo, existe uma variação externa, mas, não "tá" na escolha da pessoa. Não "tá" no... Né? Ela "tá" dentro da barriga da mãe, é um momento que acontece muito isso. Tem a parte genética e isso, também. Então, assim, é complicado você tipificar algumas coisas. Então...

Entrevistador: E esse assunto, no país, ainda é mais tabu?

Marcelo: Sim, e, assim, eu acho que "tá" rolando um enfrentamento muito grande, muito grande. E... é triste, também, porque... As pessoas, elas se posicionam, mas elas sofrem por isso. E eu acho que, atualmente, é um dos preconceitos que "tá" sofrendo mais embate, "tá" sofrendo mais perseguição. E é triste. O caso da Bienal... A gente pode citar vários casos, aí, que são muito complicados.

Entrevistador: "Cê" acha que é mais tenso, nas escolas, de abordar esse assunto?

Marcelo: Sim, com certeza. Com certeza, sempre foi. E, assim, é interessante, também - que eu já percebi na minha atuação, também, nos estágios e bolsas - que esses indivíduos, geralmente, muitas vezes, são afastados, são excluídos. E, né? Isso também influencia na aprendizagem, influencia na forma de se encontrar como aluno, como estudante. Então, são questões que são fundamentais pra se tratar em sala de aula.

Entrevistador: Na faculdade, você viu alguma coisa relacionada a isso? Diretamente ligado a esse tema?

Marcelo: Não, não. Acho que em momento nenhum foi tratado isso, assim... Nunca... Em momento nenhum foi dito, em momento nenhum foi discutido. Talvez, alguns comentários, algumas coisas assim, mas... Isso.

Entrevistador: E a gente comentou sobre o professor de Matemática levar representatividade, né, em relação ao tema do racismo. "Cê" acha que também tem que ter uma representatividade nesse tema? Comunidade LGBT+?

Marcelo: Sim, sim, e, assim, eu vi coisas muito interessantes; tem uma Youtuber, uma Youtuber que também dá aula e é uma travesti, acho que é Rita Von... alguma coisa. Ai, gente, nossa! Paixão! (risos). E... é isso. 
Entrevistador: E quem sofre esse tipo de opressão, isso também pode influenciar na aprendizagem?

Marcelo: Sim, com certeza, com certeza. Acho que não tem como. Qualquer tipo de opressão. Aí, a gente vai e pega e cita Paulo Freire, lindo e maravilhoso, também, né? Quando a educação, ela não é libertária, né, o sonho do oprimido é se tornar o opressor. E isso eu vi constantemente. Eu vi, assim, claramente, alunos que falavam que, tipo assim, “Ah, ótimo, tranquilo, uma hora vai ser a minha vez de oprimir". E isso se torna um ciclo, né, vicioso.

Entrevistador: Pode passar pro próximo assunto? As perguntas são muito parecidas, só que tem umas perguntas que eu abordo mais, umas que eu abordo menos... Só pra gente...

Escola sem partido.

Marcelo: Risos do entrevistado.

Então, então... Ô, meu Deus! (risos).

$\mathrm{Ai}$, é aquela tal coisa, né? É uma ferramenta, é uma ferramenta de opressão. É uma ferramenta pra que... é... Porque é muito mais fácil você dominar um povo burro, um povo ignorante. Um povo ignorante você consegue dominar, você consegue...

Entrevistador: Não critica, né?

Marcelo: Exatamente, não critica, não tem uma opinião formada, não tem uma voz. Então, né? É, simplesmente, uma ferramenta de opressão, porque não existe, não é uma coisa sem partido; não existe esse negócio de escola sem partido. Não existe.

Entrevistador: Não tomar um partido já é um partido, né?

Marcelo: É, exatamente. E aquela coisa, não existe esse negócio de não ter partido, sabe? Que nem eu falei, não existe isenção de uma coisa. Não existe. Você ser isento, ali, você "tá" tomando uma posição diante daquilo ali. Se você não faz nada, você "tá" fazendo alguma coisa.

Entrevistador: Sim, verdade. Então, você é contra a escola sem partido, né?

Marcelo: Não, toda certeza. Completamente. Eu acredito numa escola livre, numa escola onde não apenas os professores tenham voz, mas os estudantes, também. Estudantes também têm que ter voz. E eu não vejo isso, sabe? Professor tem medo, também, dos alunos. Professores têm medo dos alunos, de dar voz aos alunos, de ouvir a opinião deles, de saberem 
o que eles querem da escola, sabe? Grêmios, por exemplo. Caramba, cara! Isso é uma coisa tão fundamental, sabe? Tipo assim, os alunos vão respeitar muito mais regras em que eles votaram pra que fosse, pra que eles entendessem. Eles discutiam as regras pra depois poder seguir essas regras - quando ela é um consenso - sabe?

Entrevistador: Acho que é uma questão que foge também da imposição. É uma questão de construir um espaço.

Marcelo: Construir, exatamente. Porque é aquela coisa: escola são os estudantes. Não são os professores, não é da secretaria, não é do governo, não é... São dos estudantes, são dos estudantes.

Entrevistador: E a Matemática cria cidadãos críticos, pensantes nesse sentido?

Marcelo: Não.

Entrevistador: Críticos, pensantes... principalmente na matemática, né ?

Marcelo: No máximo, críticos em relação ao conteúdo.

Entrevistador: As pessoas acham que a matemática não faz o aluno pensar nesses temas sociais.

Marcelo: Pois é, durante muito tempo, eu achei que a Matemática, em si - as pessoas da Matemática, em si - todas tinham muito conhecimento e eram muito inteligentes. Poxa, tá, né? Havia aquele endeusamento da coisa, porque "pô", Matemática, querendo ou não, é uma matéria que...

Entrevistador: Supervalorizada, né?

Marcelo: Isso. Não apenas só supervalorizada, mas, de fato, é muito extensa. E, também, uma coisa que o Marco Aurélio falou, que ela entra em qualquer debate, ela "tá" em tudo; ela entra em qualquer debate, ela fala de Artes, ela cabe em tudo. Sabe? Só que não é explorado. Não é explorado.

Entrevistador: Porque o professor de Matemática tem que ensinar a fórmula de Bháskara, tem que ensinar Funções...

Marcelo: Exatamente. A repetir. Que, tipo assim, é complicado, porque isso, também, poda o pensamento crítico.

Entrevistador: Sim. 
Marcelo: Então, é complicado...

Entrevistador: Marcelo, pra encerrar, como você acha que a escola incentiva a cultura?

Marcelo: Então, é complicado, né? Bem complicado. Se você for pensar no âmbito artístico, constantemente não é uma profissão de futuro, porque não é valorizada, não tem valor, assim. Não se vive de arte, principalmente, aqui, no Brasil. Tem até um colega, um amigo da minha mãe, que ele pintava aqui no Brasil - porque ele tinha inspiração aqui no Brasil - mas, ele ia lá pra Austrália pra poder vender as obras dele. Então, assim... Não sei muito sobre o contexto fora daqui, mas, aqui, não se vive, assim... é... Meu marido, ele é tatuador e é complicado. É bem complicado. Você viver da arte é bem complicado. E é muito triste, porque tem tanto potencial. A gente vê, em várias áreas, pessoas que abriram mão daquele potencial, daquela vocação, pra viver uma outra realidade que pode ser opressora; pode não ser o lugar que a pessoa quer e, talvez, ela nem produza tanto. Talvez, ela não consiga produzir tanto, porque não é aquilo que traz paixão, sabe? Não é aquilo que dá “tesão”. Então, é complicado.

E, sim, nas escolas, também, a questão cultural, ela é muito pouco abordada, sabe? Ela é muito pouco abordada. E uma riqueza cultura é fundamental, sabe? Eu vejo, assim porque eu, também, dei uma "roletada" aí, no Brasil. Morei no Sul, morei, também, no Nordeste, e vim morar aqui, também -. E é interessante você... Porque é assim que você consegue abarcar a realidade. São bolhas, né? A gente vive em bolhas sociais que a gente não... a gente só sabe daquela realidade. As pessoas não têm consciência disso e não conseguem sair dessas bolhas. Então, é fundamental a gente quebrar, começar a quebrar essas bolhas, e ter mais noção da realidade. E, isso, a cultura é fundamental pra isso. Traz críticas políticas, traz potencial de resistência. Sem a cultura, acho que a gente nem sobreviveria resistindo sem as músicas, sem a arte, no geral. E ela é muito plural e muito rica. Aqui, no Brasil, caramba! Tenho conhecido cantores e atores e pessoas que eu não conhecia antes, porque não eram pauta da escola e... poxa! Tanta coisa rica, aí, que a gente pode trazer pras crianças, pros adolescentes. E é isso.

Entrevistador: E, só pra fechar, uma última pergunta: o que você acha, assim, da Matemática ter oito aulas por semana e Artes, por exemplo, ter só uma?

Marcelo: Risos da entrevistado.

Essa é complicada, essa é polêmica! (risos).

É “foda”, porque, assim... 
Entrevistador: Você como formada em Matemática, assim...

Marcelo: Eu, particularmente, eu acho que a gente aborda muita coisa de Matemática desnecessária para, assim... Porque, teoricamente, assim... A gente, primeiro, precisa pensar: "O que que a gente quer do Ensino Fundamental?", "O que que a gente quer do Ensino Médio?" pra, então, a gente conseguir...

Entrevistador: Elaborar uma estrutura curricular.

Marcelo: Isso, exatamente. A gente tem que pensar numa estrutura curricular pra, então, conseguir delinear isso melhor. E, assim, também existem vários tipos de escolas, várias escolas que seguem metodologias diferentes. Assim, a maioria segue a padrão, né? Mas, tem coisas diferentes, aí, surgindo. Mas... é... e coisas essenciais que deveriam ser abordadas na Matemática que a gente não aborda; Educação Financeira, prática mesmo. "Pô, eu não sei fazer imposto de renda!". Eu vou ter que fazer, eu não sei fazer imposto de renda! (risos). Eu não sei coisas básicas que poderiam ser abordadas, que seriam muito mais fundamentais socialmente, são necessárias, mas, não são abordadas. E, em compensação, a gente também aborda coisas que também não são tão úteis, digamos assim. Mas, é complicado delinear isso. Agora, Artes? Poxa, é questão cultural mesmo, eu acho que é muito rica. Tem muita coisa pra ser abordada, muita potencialidade. E eu também acho que seria muito interessante, também, haver um direcionamento mais individual, sabe? As pessoas que têm mais vocação, mais tato "praquela" área, também. Não só seguir aquilo - porque eu acho que tem coisas que são fundamentais e todo mundo, né, tem que ter - mas, também, ser uma coisa mais individual e cada um seguir um caminho... Apesar de, também, ter um conteúdo geral, aí, que tem que ser abordado.

Entrevistador: Muito obrigado, Marcelo, pelo seu tempo. 


\section{ANEXO B - DOCUMENTÁRIO TRANSCRITO}

Escola, sala de aula. Grande misto de barulhos ao fundo. Muitas pessoas conversando. Nessa sala, um aluno, nitidamente desconfortável, por ser alvo constante de piadas e de brincadeiras maldosas.

Gabi: Professor, você não vai fazer nada?

Professor Marcelo: Eu até gostaria de falar sobre esse assunto, mas a diretora não gosta, não vou entrar nesse tipo de assunto agora, tá bom, gente? Por favor.

O aluno sai da sala, fortemente abalado pela situação e pela fala do professor.

Entrevistador (Alexandre): Professor, agora, as pessoas estão discutindo mais sobre a comunidade LGBTQIA+. Você tem alguma coisa pra falar em relação a esse tema? Você já abordou esse tema em sala de aula? Conhece algum aluno que é da comunidade LGBTQIA+?

Professor Henrique: É... eu não, eu não... O que que acontece: são assuntos que rodeiam nossa cabeça desde que a gente é criança, né, desde que a gente é menino, porque a gente identifica os afeminados desde sempre, né? Então, é... Na minha sala tem também, mas eu tento... eu tento... a gente luta tanto por igualdade, né, eu tento tratar todo mundo igual.

Professora Ivani: Olha, antes de falar desse assunto, eu queria dizer que nós não somos, nós, professores, não somos preparados pra isso. Para isso existe médico, psicólogo... Eu não tenho aparato psicológico, físico, clínico pra abordar isso com o aluno. Isso aí tem que ser um profissional da área.

Professora Amanda: Chegando pra dar aula, eu encontrei um menino, tive uma conversinha, assim, de dois minutos com ele, ele perguntou se eu dava aula lá, eu falei que dava, ele me contou que 'tava' tentando uma vaga, aí, eu falei ‘que legal!' e tal, e entrei. Quando eu entrei lá, a diretora me chamou pra conversar e falou: 'olha, a gente vai ter que lidar com uma situação um pouco delicada, aqui, agora, porque tem um menino que era menina e 'tá' entrando na escola, e os outros alunos não podem saber... é... Isso me fez entender e ver, né, de perto, o quanto a escola não sabe receber. 
Professora Ivani: Pra você ter uma ideia, teve um acontecimento, né, aqui, na cidade de Juiz de Fora, numa escola muito conhecida, em que uma drag queen foi lá, no dia... foi dia das crianças? (a professora para e pensa um pouco). Acho que foi... E foi uma abordagem interessante? Foi uma ideia interessante? Sim, mas num momento nada interessante, né? Criou-se toda uma situação desagradável, né, não estávamos vivendo um momento político propício 'praquela' situação toda acontecer. Então, aí, gerou foi um desconforto pros pais, pros alunos, né? Pensa nas questões das famílias, como é que encararam aquela situação? Então, eu acho que não era o momento, sabe? Existem outras ocasiões pra isso ser abordado, levado pras crianças.

Professor Henrique: Mas eu não tenho uma formação, uma... uma... porque os meus amigos, eles sempre foram héteros, eu não convivi com esse tipo de... com essas... com esses outros segmentos, né, então, eu não sei nem te falar direito. A gente sabe muito superficialmente, quando a gente não vive com essas pessoas direito, né?

Professora Amanda: Porque tem a questão do nome, tem a questão do banheiro... que a escola tem que estar pronta pra lidar. E essa escola não soube receber. A diretora queria esconder, é... os alunos não podiam saber, não sabia como encaminhar pra qual banheiro que ia, não sabia se ia conseguir receber... E aí, você pensa, pra ele, pra esse rapaz, como que é? 'Tá' passando pela terceira escola e encontrar essa dificuldade pela terceira vez. Enfim, a escola não sabe receber...

O aluno do começo do vídeo, que sofria Bullying no ambiente escolar, caminha pelas ruas da cidade até chegar em casa:

Felipe: Pai? Mãe?

O aluno fecha a porta de casa, deixa sua mochila na sala, entra em outro cômodo da casa e começa a mexer em algumas gavetas.

Entrevistador (Alexandre): Agora, em relação à Gênero e Sexualidade, eu queria que você falasse pra gente se você já viveu alguma situação em que já precisou abordar esse assunto, se você acha que deve ser abordado esse assunto dentro da escola. O que você pensa sobre isso? 
Professora Amanda: O tempo todo, a gente se depara com temas, dentro da sociedade, que eles gritam por atenção. É... Vou te dar um exemplo: 'tô' lembrando aqui, uma sala de aula, foi pra uma turma do Ensino Médio. Isso não acontece só Ensino Médio, mas foi uma coisa que eu lembrei aqui, agora. É... que 'tava' tendo um embate de meninos e meninas, né, eles estavam brigando, e foi colocado, ali, os meninos colocaram como se as meninas fossem quaisquerzinhas; foi até essa palavra que ele usaram, ali, dentro da briga deles. Eles usaram essa palavra, quaisquerzinhas. É... eu não pude deixar passar, eu não tinha tido que passar por uma situação dessa, até o momento, mas, quando isso aconteceu, tive que parar pra pensar; eu, infelizmente, no momento, eu não tinha ouvido, mas as meninas falaram 'professora, você viu? Aconteceu isso...' e eu procurei uma forma de resolver. Eu fiz um trabalho em que eles tinham que estudar, pesquisar a importância da mulher na sociedade.

Professor Henrique: Então, relacionado a essa questão do feminismo, né, eu acho lindo essa luta toda, mas assim, tem algumas da classe que fica até difícil levar em consideração. Tem uma colega de trabalho - vou abrir, aqui, pra vocês - é... você precisa de ver como ela se veste. Eu não sei nem como os alunos levam ela em consideração, sabe?

Professor Marcelo: Eu concordo, acho que deve tratar, sim, Gênero e Sexualidade na escola, é... não é ensinar a criança a fazer sexo. Não! É explicar, né, falar pra criança, pra ela entender o próprio corpo dela, o que que 'tá' acontecendo, principalmente aí, se a gente for trabalhar com adolescente, né? No caso de um abuso, ela entender que aquela área, ali, o parente, o tio ou quem for, qualquer estranho que for, que ali é errado tocar... é... pra criança não ser vítima, parar com esse tipo de situação, pra ela aprender a denunciar. Essas são as propostas de você tratar isso dentro de sala de aula, e eu acho isso muito válido.

Professora Amanda: Inclusive, como professora de Matemática, eu, quando eu 'tava' na faculdade ainda, eu sempre... na faculdade nada! Quando eu 'tava' na escola, eu sempre via essa predileção, em relação a meninos, pra ser... que eram mais inteligentes, tinham mais facilidade com Matemática... Tinha uma escola que eu trabalhava e tinha uma outra figura lá, vou definir como "figura"; era um homem, branco, heterossexual, super certinho, com um currículo muito extenso... E todas as vezes que a gente ia fazer uma reunião, eu começava a desenvolver alguma coisa, a falar alguma coisa, e ele me interrompia, ele falava mais alto, eu nunca conseguia concluir um raciocínio... e isso me incomodava muito. 
Entrevistador (Alexandre): Professora Ivani, quando a gente fala de Racismo na sala de aula, o que a senhora pensa a respeito desse tema?

Professora Ivani: Olha, eu penso que é um assunto ainda tratado com... com muita parcimônia, entendeu? As pessoas tratam de forma pontual; isso tinha que ser uma forma generalizada desde a Educação Infantil, né? É... você não tratar só do tema racismo, vamos pensar, cor da pele, que hoje é tão falado? Não. 'Cê' tem que tratar cor do cabelo, tamanho do nariz, altura, cor dos olhos... Tem que ser uma coisa geral, não pode ser uma coisa específica, entendeu? Tem que ser uma coisa desde criança e generalizado, por que esse negócio de ficar falando só da cor da pele, parece que só existe essa diferença.

Professor Marcelo: As pessoas falam que racismo é uma coisa distante, mas não é, a escravidão foi logo ali, meu bisavô, tataravô foi escravo. 'Cê' vai falar que escravidão não existe hoje em dia? Não 'vamo' falar assim, 'A escravidão', mas o lugar em que os negros estão inseridos; e são lugares de servir as pessoas. Eu vou num restaurante, eu vejo pessoas negras; os negros ainda são, dentro do gráfico social, na pesquisa, hoje, as pessoas mais pobres são as pessoas mais negras, e isso é muito complicado.

Professor Henrique: É igual a gente falando sobre mérito, né, a questão da meritocracia, a questão das cotas na universidade. Eu sou totalmente contra. Eu acho que: não quer igualdade? A gente tem que bater de igual pra igual. Eu não sei se é interessante pro negro ser visto de 'ah, tá aqui, na cota'. Eu acho que seria interessante pra ele 'ah, eu tô aqui, porque eu passei igual todo mundo'.

Entrevistador (Alexandre): Entendi...

Um homem negro é abordado, andando na rua, por um policial que diz:

- Ei, ei, encosta aí, rapaz, encosta aí.

- Que isso, não tenho nada, não, sou estudante, ou!

O policial encosta o rapaz em um muro, aponta uma arma e diz:

- Você 'tá' achando que 'tô' brincando? 'Cê' fica quieto aí.

- Eu sou estudante, cara. 
- 'Vamo' ver se é estudante mesmo, todos são.

Os policiais revistam o rapaz e seus pertences.

- É, não tem nada, não...

- Não falei?

O rapaz vai embora, mas senta na calçada muito abalado. Em seguida, levanta e continua andando pelas ruas, ainda muito abalado.

Professor Marcelo: 'Cê' vai nos lugares, por exemplo, 'cê' vê, 'cê' é atendido por médicos negros? Não. Engenheiros negros, arquitetos negros que vão reformar uma casa? Não. São pessoas brancas. Por que que as pessoas são contra negros ocupando esses espaços, né? Porque tem gente que fala assim 'ah, tem que melhorar a educação', mas também não é assim, 'vamo' olhar dentro do jogo político, social, é... 'vamo' fazer essa justiça, nós queremos construir uma população mais justa, vamos dizer assim, então precisa, sim, das cotas, a gente precisa colocar negros na universidade. Eu entrei por cotas na universidade, eu sei a importância que isso teve pra mim.

Professora Ivani: Penso em Brasil, hoje, só existe negro pobre? Não. Existe uma diversidade de pessoas, é branco, negro, amarelo, índio. Então, 'cê' falar do negro, separar cotas pro negro, acho que aí, isso sim, é um preconceito.

Entrevistador (Alexandre): O senhor já presenciou alguma cena de racismo na sua sala de aula? Como que foi? O senhor tem algum relato pra dar pra gente?

Professor Henrique: Eu já presenciei muitas vezes, mas... o meu pai era professor também, então, eu acho que eu vim com isso meio que de casa, né, ele me passou várias coisas. Como eu falei, a minha sala de aula é meu campo. Lá, quem dita as regras sou eu. Quando eu vejo isso acontecendo, é direto: 'Opa! Aqui quem manda sou eu, esse assunto não se fala aqui, vamo focar na aula'. É isso que eu acredito.

Professor Marcelo: Já fui ‘dum’ cabelo da menina, um menino implicou 'ah, porque o seu cabelo é bombril'. A menina começou a chorar, e é até um pouco assim... eu 'tô' falando de racismo, é uma coisa muito pessoal, né, porque eu sou negro, e ver esse tipo de coisa, cara, dá vontade de prender o menino, mas você tem que ser ético, né? Mas a menina começou a chorar e... como é que 'cê' sai? 'Cê' leva a menina, 'cê' conversa... o que 'cê' tem que fazer é 
levar o menino pra secretaria, são essas coisas que ‘tão' no nosso alcance. Mas isso... o cabelo é uma forma de resistência, principalmente da mulher, né, a mulher preta. E essas coisas acontecerem dentro de sala de aula é uma coisa que fere a mim, pessoalmente.

Professora Ivani: Pra você ver uma coisa - vou até usar um argumento de verdade pra isso: existe branco no Brasil? Ninguém é branco, no Brasil. Todo mundo é negro, todo mundo é... é uma mistura isso aqui.

Professora Amanda: A gente toca muito nessa coisa de 'nossa, eu senti na pele, doeu tanto', e quando é com o outro, a gente não tem essa mesma sensibilidade; eu acho que o que 'tá' faltando, nas pessoas, é essa sensibilidade, porque quando é com o outro - às vezes, você vê uma situação de racismo, de intolerância religiosa perto de você - e você deixa passar batido, porque aquilo não 'tá' te doendo. 'Cê' não sentiu na sua pele. E passa batido.

Rodrigo, que anteriormente foi abordado pelos policiais esbarra em Gabi na rua:

- Desculpa.

- Oi!

- Oi, Gabi.

- Como você 'tá'? Você não tem ido na aula...

- Aconteceu umas coisas aí, mas 'tá' tudo bem agora.

- Tá mesmo? 'Cê' viu o Felipe?

- Não não, também não sei onde ele 'tá'.

- Se você souber de alguma coisa, você me fala, tá?

- Tá bom, beleza. Tchau.

- Tchau.

Cena da Gabi escrevendo e cantando.

- Felipe, 'tô' preocupada com você, 'cê' não mandou nada. O que 'tá' acontecendo? Manda alguma coisa, 'tô' preocupada mesmo. 
Professora Amanda: As pessoas veem a escola, assim, como um sacro-lugar; que é, assim, santificado, tem que ser separado, uma coisa distante, ali, e não é assim. Hoje, eu vejo que a escola é como se fosse um recorte da sociedade.

Professor Marcelo: Escola sem partido é absurdo. É uma forma de opressão sem igual, e os professores, dependendo do tipo de escola, o professor já não tem o controle...

Professor Henrique: Eu acho que falta os princípios, a moral... Eu era uma pessoa que cantava o hino nacional na escola, eu olhava pra bandeira, sabe? Hoje, a galera não sabe nem o hino. Então, assim, eu acho que a gente 'tá' preocupando com outros assuntos, de outras áreas, e esquecendo o primordial, que é aprender, que é valorizar a família, entendeu? Eu acredito nisso.

Professor Marcelo: Qual o papel da escola? Por que o êxodo escolar, hoje em dia, né? Que escola é obrigatório pra todo mundo, por que tem muitas crianças negras fora da escola? Elas se sentem humilhadas de alguma forma, repreendidas, não se sentem pertencentes àquele ambiente. Então, a escola, principalmente, a escola pública, é um ponto de interrogação; qual que é o papel da escola?

Professora Ivani: Pensando em questões financeiras, idade, tudo vai se alinhar quando você pensar no Capitalismo. Então, a Matemática tem que ser vista de cima, essa é a verdade.

Cena: rapaz, anteriormente abordado pelo policial, em casa, no computador, comemorando Gabi: A professora mandou mensagem, deixa eu ver.

Olá, meninos e meninas, tudo bem com vocês? Eu espero que sim.

Então, eu já tive a oportunidade de confirmação aqui e, realmente, a gente não vai mais ter aula, né, eu não vou dar mais aula pra vocês, por enquanto. Mas, mesmo assim, eu queria fazer uma reuniãozinha com vocês, hoje, às sete, fica bom pra vocês? Todo mundo pode? Me mandem aí...

Gabi: Ai, tá bom, né... 
Uma pandemia surgiu e ninguém sabia qual era a gravidade desse vírus. Com ela, algumas situações, que pareciam pequenas e inofensivas, pioraram.

Música de fundo.

Cena da professora, espancada, chorando.

- Alô, é da delegacia da mulher?

Professora Amanda: Oi, gente, desculpa, eu 'tava' com uns pensamentos aqui, mas 'vamo' voltar pra aula... Cadê o Felipe? Alguém sabe dele aí?

Cena do Felipe se maquiando. Música final. 


\section{ANEXO C - Termo de autorização de uso de imagem e voz \\ TERMO DE AUTORIZAÇÃO DE USO DE IMAGEM E VOZ MESTRADO PROFISSIONAL EM EDUCAÇÃO MATEMÁTICA}

Neste ato, e para todos os fins de direito, autorizo o uso da minha imagem e da minha voz para fins de pesquisa e divulgação do trabalho do mestrando Alexandre Jenevain Junior na produção do seu documentário na instituição Universidade Federal de Juiz de Fora - UFJF, em caráter definitivo e gratuito.

As imagens e voz poderão ser exibidas: parcial ou total em apresentação audiovisual, publicações e divulgações para fins acadêmicos e festivais com ou sem premiações remuneradas nacionais e internacionais, assim como disponibilizadas nos bancos de dados resultantes de pesquisas e em outras mídias futuras, fazendo-se constar os devidos créditos à produção do Mestrado Profisssional em Educação Matemática.

Por ser esta a expressão de minha vontade, nada terei a reclamar a título de direitos conexos à minha imagem e voz ou qualquer outro.

de de 20

Assinatura

Nome:

RG: CPF:

Telefone 1: Telefone 2:

Endereço

Cidade: Estado: 


\section{TERMO DE AUTORIZAÇÃO DE USO DE IMAGEM E VOZ MESTRADO PROFISSIONAL EM EDUCAÇÃO MATEMÁTICA}

Neste ato, e para todos os fins de direito, autorizo o uso da minha imagem e voz para fins de pesquisa e divulgação do trabalho do mestrando Alexandre Jenevain Junior na produção do seu documentário na instituição Universidade Federal de Juiz de Fora UFJF, em caráter definitivo e gratuito.

As imagens e voz poderão ser exibidas: parcial ou total em apresentação audiovisual, publicações e divulgações para fins acadêmicos e festivais com ou sem premiações remuneradas nacionais e internacionais, assim como disponibilizadas nos bancos de dados resultantes de pesquisas e em outras mídias futuras, fazendo-se constar os devidos créditos à produção do Mestrado Profissional em Educação Matemática.

Por ser esta a expressão de minha vontade, nada terei a reclamar a título de direitos conexos à minha imagem e voz ou qualquer outro.

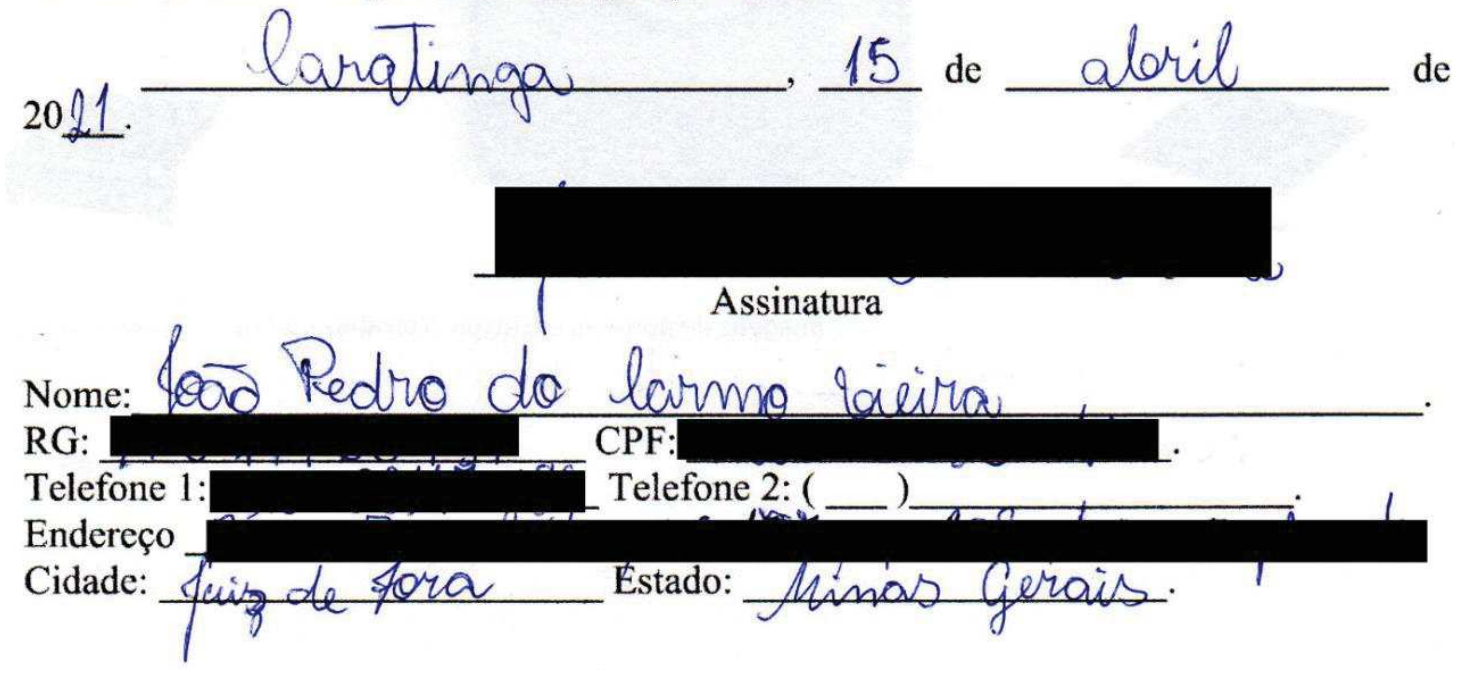


TERMO DE AUTORIZAÇÃO DE LSO DE IMAGEM E VOZ MESTR IDO PROFISSIONAL EM EDECACẢO MATEMATICA

Neste ato, e para todos os fins de dirvito, autorizo o uso da minha imsgem e voz para fins de pesquisa e divulgaçato do trabatho do mestrando Alexandire Jenievain Jurior sa produça do seu documentario na instituiçăo Universidade Federal de Juiz de Fora UFHF, em cardter definitiso e gratuito.

As imagens e voz poderăo ser exibidas: porcial ou total em apresetitacio aedioxistal, pablicaches e divulgaçes para fins actadémices e festivais com ou sem premaçōes remuneradas nacionais $\mathrm{e}$ internacionais, assim como disponibilzzadas nog bancos de dados resultantes de pesquisas e en outras midias fusuras, faxendo-se constar os devidos créditos ù prođução do Mestrado Profissional em Educaça Matera tica. Poy ser esta a expressảo de minha vontade, nada terei a reclamar a título de direitos

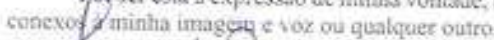

208

Cuig de Fora- MG 08 is Outuber de

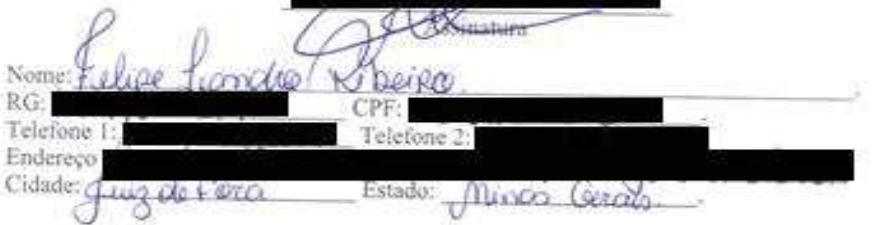


TERMO DE AUTORIZACIO DE LSO DE IMAGEM E YOZ MESTRADO PROFISSIONAL EM EDUCAÇÃO MATEMATICA

Neste ato, e para todos os fins de direito, autorizo o uso da minha imagem e voz para fins de pesquiss e divulgasalo do trabaltho do mestrando Alexandre Jencwain Junior na produçào do seu documentario na instituişào. Universidade Federal de Juiz de Fora UEJF, $\mathrm{em}$ caraiter definitivo e gratuito.

As imagens e vor poderìo set exibidas: pancial ou total em apresentaçào

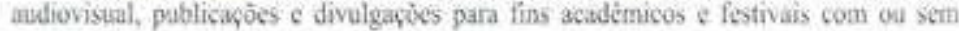
premiaçes remuneradas nacionais e internacionaik, assim como disponibilizadas nos bancos de didos resultantes de pesquisas e em outras midias futuras, fazctodo-se constar

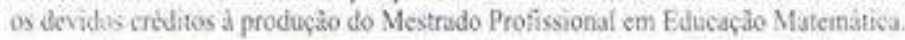

Por ser esta a expressão de minta vontade, nada terei a reclumar a titulo de fireitos conexos a minha intagen e vol ou qualquer outro.

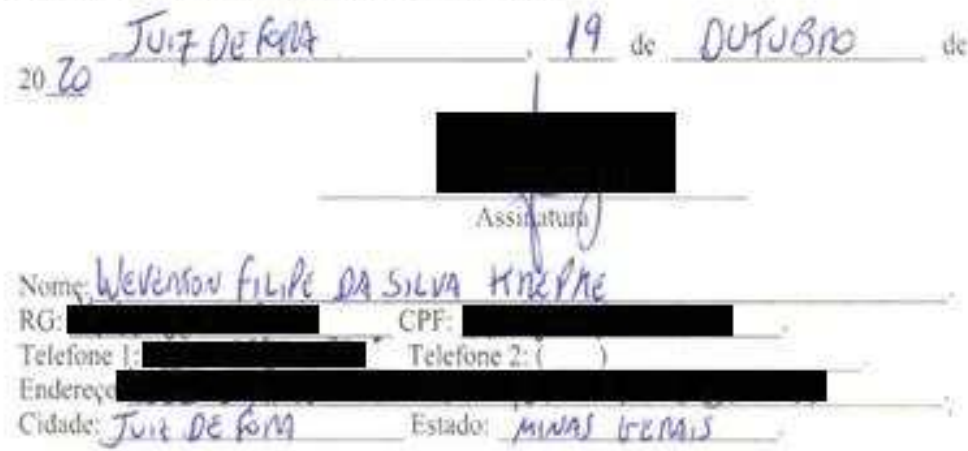




\section{TERMO DE AUTORIZAÇÃO DE USO DE IMAGEM E VOZ MESTRADO PROFISSIONAL EM EDUCAÇÃO MATEMÁTICA}

Neste ato, e para todos os fins de direito, autorizo o uso da minha imagem e voz para fins de pesquisa e divulgação do trabalho do mestrando Alexandre Jenevain Junior na produção do seu documentário na instituição Universidade Federal de Juiz de Fora UFJF, em caráter definitivo e gratuito.

As imagens e voz poderão ser exibidas: parcial ou total em apresentação audiovisual, publicações e divulgạ̧̄es para fins acadêmicos e festivais com ou sem premiaçōes remuneradas nacionais e internacionais, assim como disponibilizadas nos bancos de dados resultantes de pesquisas e em outras midias futuras, fazendo-se constar os devidos créditos à produção do Mestrado Profissional em Educação Matemática.

Por ser esta a expressão de minha vontade, nada terei a reclamar a título de direitos conexos à minha imagem $\mathrm{e} v \mathrm{z}$ ou qualquer outro.

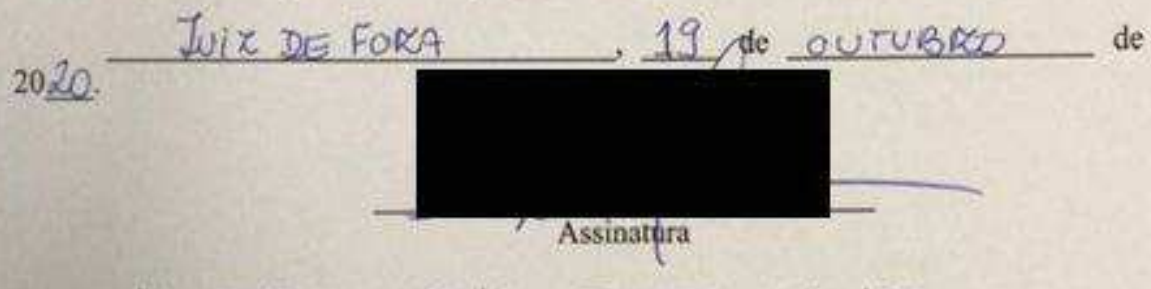

Nome: LISANDKA FERREIRA DANTAS MOREIKA

RG:

Telefone 1:

Endereço

Cidade: WULE FERA

CPF:

Telefone 2: ( )

de 


\section{TERMO DE AUTORIZAÇĀO DE USO DE IMAGEM E VOZ MESTRADO PROFISSIONAL EM EDUCAÇÃO MATEMÁTICA}

Neste ato, e para todos os fins de direito, autorizo o uso da minha imagem e voz para fins de pesquisa e divulgação do trabalho do mestrando Alexandre Jenevain Junior na produção do seu documentário na instituição Universidade Federal de Juiz de Fora - UFJF , em caráter definitivo e gratuito.

As imagens e voz poderão ser exibidas: parcial ou total em apresentação audiovisual, publicações e divulgações para fins acadêmicos e festivais com ou sem premiações remuneradas nacionais e internacionais, assim como disponibilizadas nos bancos de dados resultantes de pesquisas e em outras mídias futuras, fazendo-se constar os devidos créditos à produção do Mestrado Profissional em Educação Matemática.

Por ser esta a expressão de minha vontade, nada terei a reclamar a título de direitos conexos à minha imagem e voz ou qualquer outro.
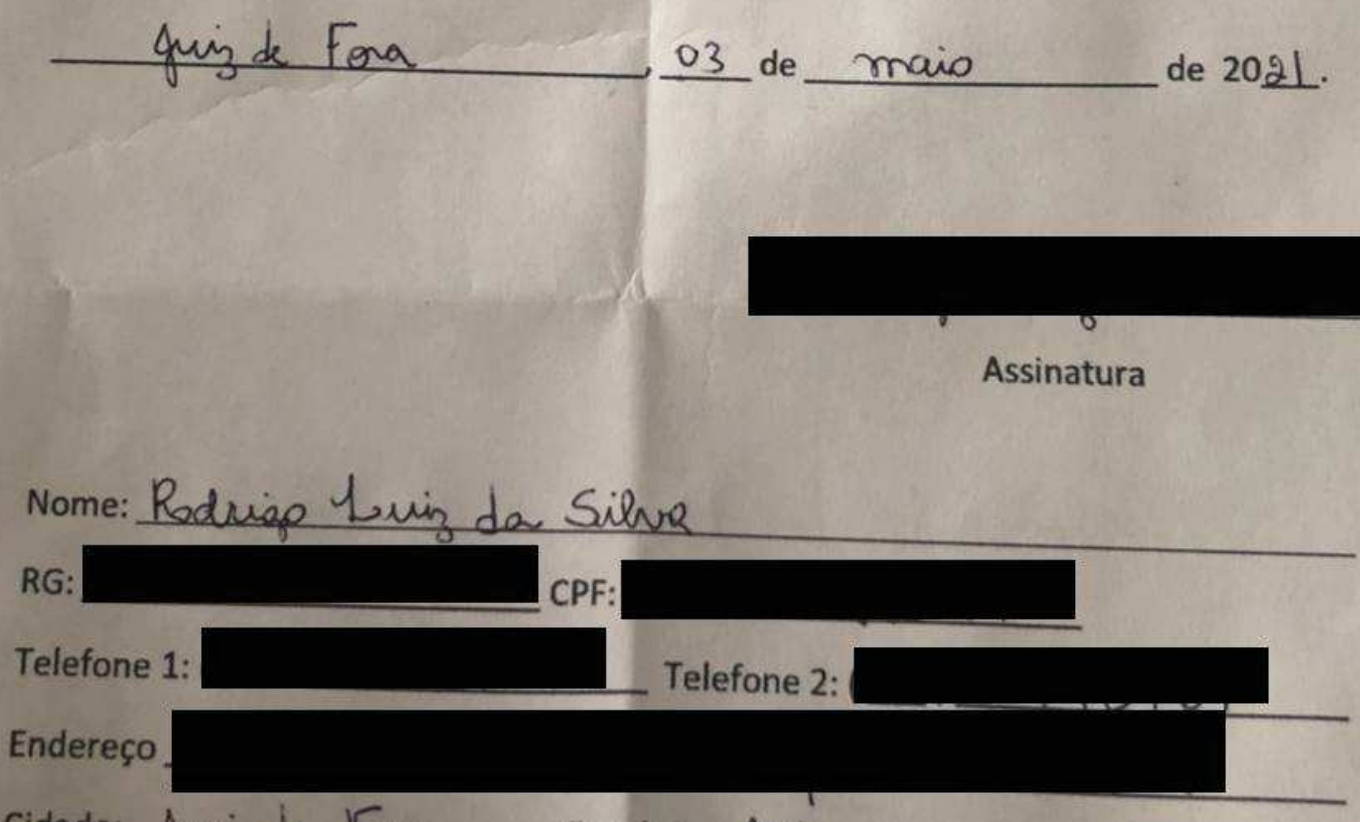

Cidade: Juiz de Fona Estado: MG 


\section{IIERMO DE AUTORIZAÇÃO DE USO DE IMAGEME VOZ MESTRADO PROFISSIONAL EM EDUCAÇÃO MATEMATICA}

Neste ato, e para todos os fins de direito, autorizo o uso da minha imagem e voz para fins de pesquisa e divulgacio do trabalho do mestrando Alexandre Jenerain Junior na produção do seu documentírio na instituiç̄o Universidade Federal de Juiz de Fora UESF, em carater definitivo e gratuito.

As imagens e voz poderão ser exibidas: parcial ou total em apresentaçào audiovisual, publicaçōes e divulgaçōes para fins acadèmicos e festivais com ou sem premiaç̧es remuneradas nacionais e internacionais, assim como disponibilizadas nos bancos de dados resultantes de pesquisas e em outras midias futuras, fazendo-se constar os devidos créditos à produçào do Mestrado Profissional em Educação Matemática.

Por ser esta a expressảo de minha vontade, nada terei a reclamar a titulo de direitos conexos à minha imagem e voz ou qualquer outro.

Juiz de Fora, 08 de outubro de 2020.

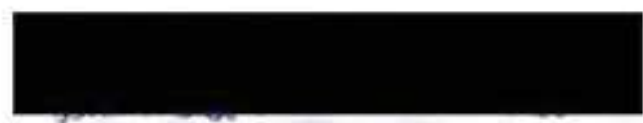

Assinatura

Nome: Luan Pedretti de Castro Ferreira

RG: ICPE:

Telefone 1:

Endereço

Telefone 2:

Cidade: Juiz de Foca. Estade: Minas Gerais. 


\section{TERMO DE AUTORIZAÇÃơ DE USO DE IMAGEM E VOZ MESTRADO PROFISSIONAL EM EDUCAÇÃO MATEMÁTICA}

Neste ato, e para todos os fins de direito, autorizo o uso da minha imagem e voz para fins de pesquisa e divulgação do trabalho do mestrando Alexandre Jenevain Junior na produção do seu documentário na instituiçăo Universidade Federal de Juiz de Fora UFJF, em caráter definitivo e gratuito.

As imagens e voz poderঝ̊o ser exibidas: parcial ou total em apresentação audiovisual, publicaçōes e divulgações para fins acadêmicos e festivais com ou sem premiaçōes remuneradas nacionais e internacionais, assim como disponibilizadas nos bancos de dados resultantes de pesquisas e em outras mídias futuras, fazendo-se constar os devidos créditos à produção do Mestrado Profissional em Educação Matemática.

Por ser esta a expressão de minha vontade, nada terei a reclamar a título de direitos conexos à minha imagem $\mathrm{e}$ voz ou qualquer outro.

$20 \underline{20}$

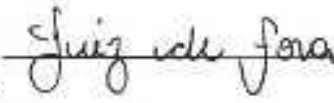

,$O B$ de

Qudubro de

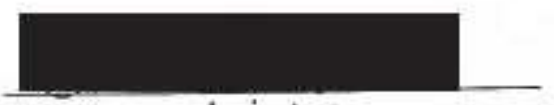

Assinatura

Nome: Śtalo Brumg de Paula Pontes

RG: CPF:

Telefone 1: _ _ Telefone 2:

Endereço

Cidade:

Juif de fone. Estado: Mimon geran 


\section{TERMO DE AUTORIZACÃO DE USO DE IMAGEM E VOZ MESTRADO PROFISSIONAL EM EDUCACÃO MATEMÁTICA}

Neste ato, e para todos os fins de direito, autorizo o uso da minha imagem e voz para fins de pesquisa e divulgaçào do trabalho do mestrando Alexandre Jenevain Junior na produção do seu documentário na instituiçăo Universidade Federal de Juiz de Fora UFJF, em caráter definitivo e gratuito.

As imagens e voz poderâo ser exibidas: parcial ou total em apresentaçăo audiovisual, publicaçóes e divulgaçōes para fins acadêmicos e festivais com ou sem premiaçōes remuneradas nacionais e internacionais, assim como disponibilizadas nos bancos de dados resultantes de pesquisas e em outras midias futuras, fazendo-se constar os devidos créditos à produçāo do Mestrado Profissional em Educação Matemática.

Por ser esta a expressảo de minha vontade, nada terei a reclamar a titulo de direitos conexos à minha imagem e voz ou qualquer outro.

2020

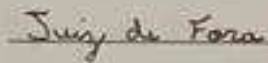

Q8 de outubroe de

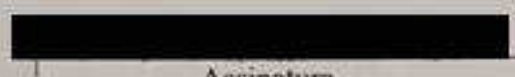

Assinatura

Nome: Harrana Hackade Junurim

RG:

Telefone 1: CPE:

Endereç

Cidade:

Juy de Fara

Telefone 2:

Estado: Rimat Gerove 


\section{TERMO DE AUTORIZAÇÃO DE USO DE IMAGEM E VOZ \\ MESTRADO PROFISSIONAL EM EDUCAÇÃO MATEMÁTICA}

Neste ato, e para todos os fins de direito, autorizo o uso da minha imagem e voz para fins de pesquisa e divulgaçăo do trabalho do mestrando Alexandre Jenevain Junior na produça do seu documentário na instituição Universidade Federal de Juiz de fora - UFJF, em caráter definitivo e gratuito.

As imagens e voz poderăo ser exibidas: parcial ou total em apresentaçăo audiovisual, publicaçōes e divulgaçōes para fins académicos e festivais com ou sem premiaçōes remuneradas nacionais $e$ internacionais, assim como disponibilizadas nos bancos de dados resultantes de pesquisas e em outras midias futuras, fazendo-se constar os devidos créditos à produçăo do Mestrado Profissional em Educaçăo Matemática.

Por ser esta a expresstâo de minha vontade, nada terel a reclamar a título de direitos conexos à minha imagem e voz ou qualquer outro.
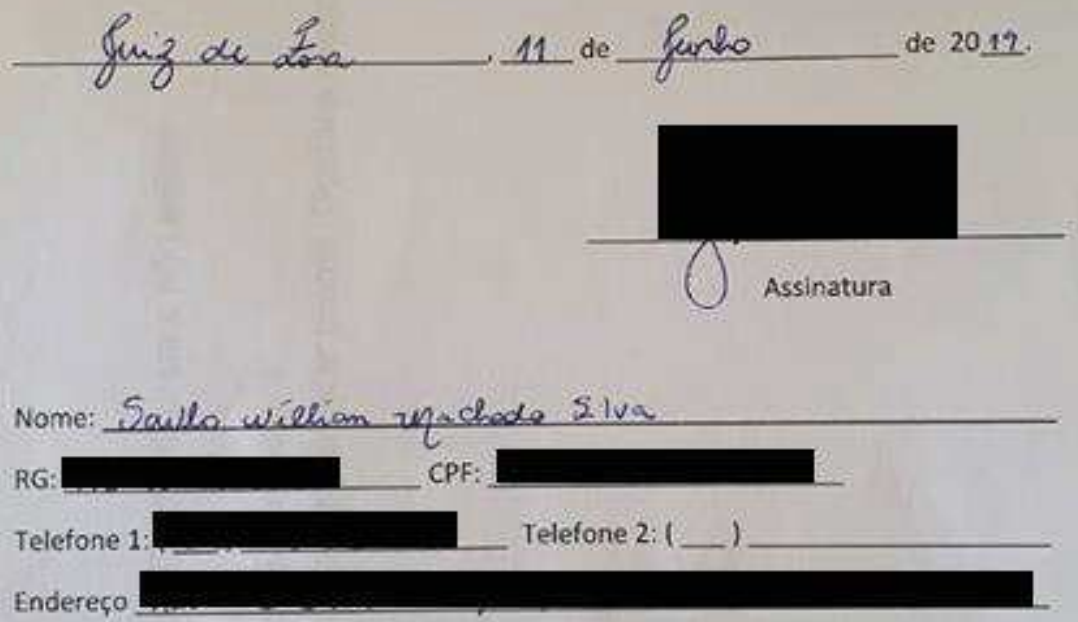

Cidade: $\operatorname{Qug}$ or Far Estado: Imines Guin 


\section{TERMO DE AUTORIZAÇÃO DE USO DE IMAGEM E VOZ MESTRADO PROFISSIONAL EM EDUCAÇÃO MATEMÁTICA}

Neste ato, e para todos os fins de direito, autorizo o uso da minha imagem e voz para fins de pesquisa e divulgação do trabalho do mestrando Alexandre Jenevain Junior na produção do seu documentário na instituição Universidade Federal de Juiz de Fora UFJF, em caráter definitivo e gratuito.

As imagens e voz poderão ser exibidas: parcial ou total em apresentação audiovisual, publicações e divulgações para fins acadêmicos e festivais com ou sem premiações remuneradas nacionais e internacionais, assim como disponibilizadas nos bancos de dados resultantes de pesquisas e em outras mídias futuras, fazendo-se constar os devidos créditos à produção do Mestrado Profissional em Educação Matemática.

Por ser esta a expressão de minha vontade, nada terei a reclamar a título de direitos conexos à minha imagem e voz ou qualquer outro.

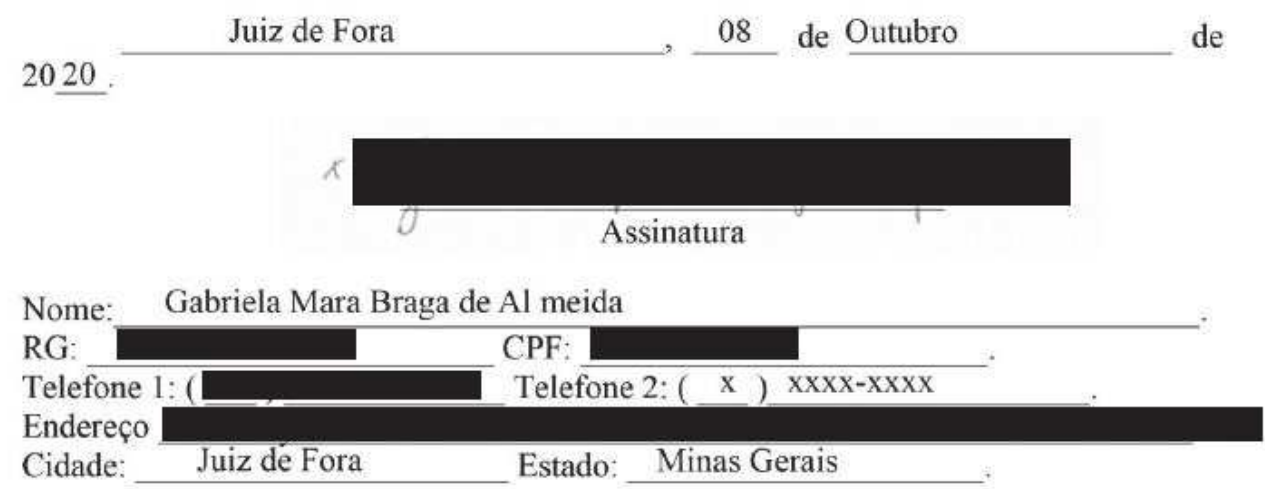




\section{TERMO DE AUTORIZAÇÃO DE USO DE IMAGEM E VOZ MESTRADO PROFISSIONAL EM EDUCACC̄O MATEMÁTICA}

Neste ato, e para todos os fins de direito, autorizo o uso da minha imagem e voz para fins de pesquisa e divulgaçăo do trabalho do mestrando Alexandre Jenevain Junior na produção do seu documentário na instituiçāo Universidade Federal de Juiz de Fora - UFJF, em caráter definitivo e gratuito.

As imagens e voz poderăo ser exibidas: parcial ou total em apresentaçăo audiovisual, publicaçōes e divulgaçōes para fins acadêmicos e festivais com ou sem premiaçōes remuneradas nacionais e internacionais, assim como disponibilizadas nos bancos de dados resultantes de pesquisas e em outras midias futuras, fazendo-se constar os devidos créditos à produçăo do Mestrado Profissional em Educaçăo Matemática.

Por ser esta a expressăo de minha vontade, nada terel a reclamar a título de direitos conexos à minha imagem e voz ou qualquer outro.

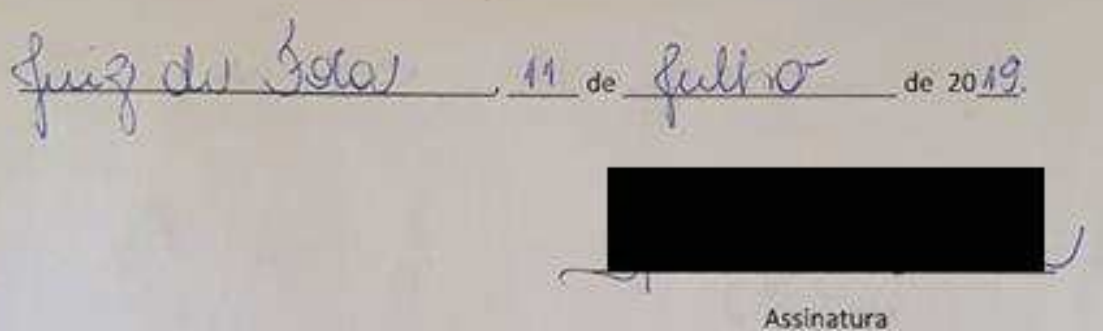

Assinatura

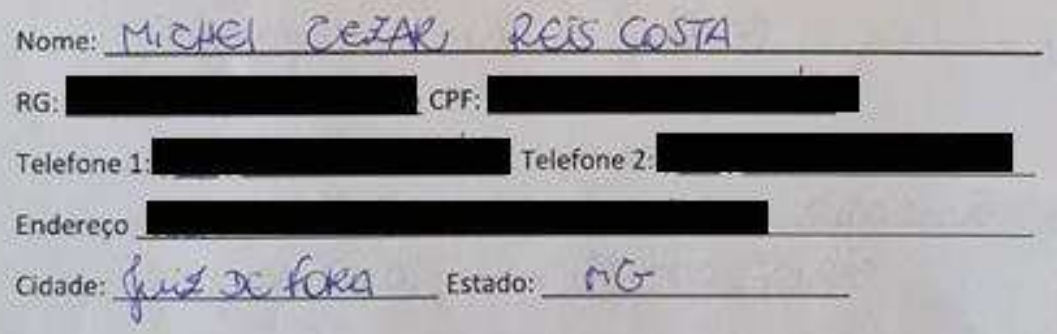




\section{TERMO DE AUTORIZAÇÄO DE USO DE IMAGEM E VOZ MESTRADO PROFISSIONAL EM EDUCAÇÃO MATEMÁTICA}

Neste ato, e para todos os fins de direito, autorizo o uso da minha imagem e voz para fins de pesquisa e divulgaçăo do trabalho do mestrando Alexandre Jenevain Junior na produçäo do seu documentário na instituiç̧ăo Universidade Federal de Juiz de Fora - UFJF, em caráter definitivo e gratuito.

As imagens e voz poderăo ser exibidas: parcial ou total em apresentaç్̧̄o audiovisual, publicaçōes e divulgaçóes para fins académicos e festivais com ou sem premiaçōes remuneradas nacionais e internacionais, assim como disponibilizadas nos bancos de dados resultantes de pesquisas e em outras mídias futuras, fazenda-se constar os devidos créditos à produção do Mestrado Profissional em Educaçăo Matemática.

Por ser esta a expressāo de minha vontade, nada terei a reclamar a título de direitos conexos à minha imagem e voz ou qualquer outro.
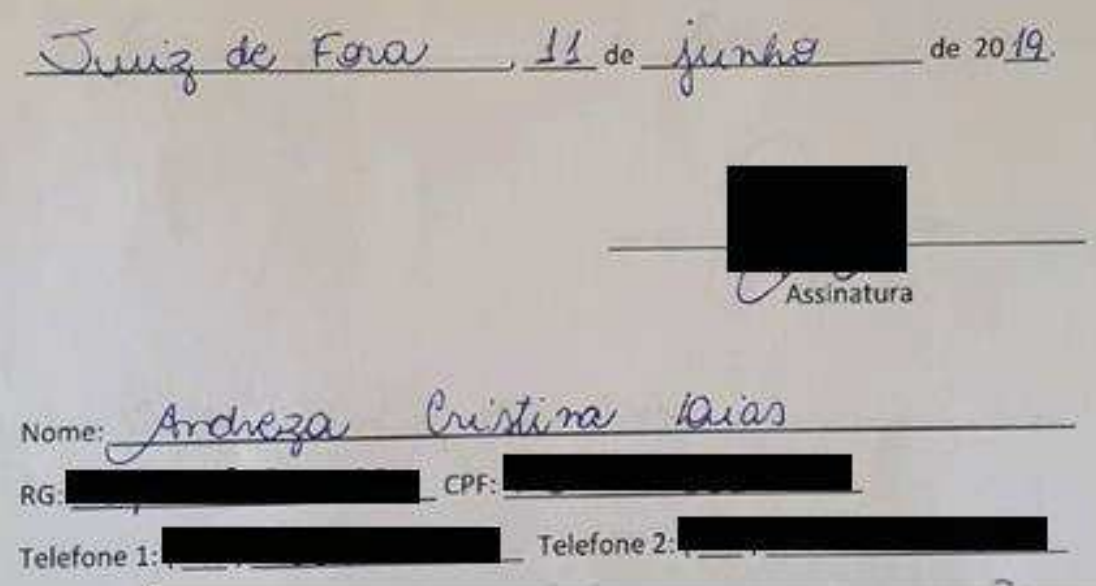

Endereço

cidade: Luif de Fora Estado: Minas Gerais 
ANEXO D - Direitos Autorais das Músicas

\section{Maria da Vila Matilde - Elza Soares}

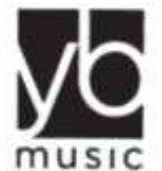

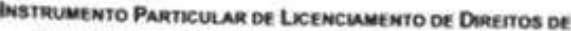

Sincronizacao de Fonogramas Musicaus eu Vloeo

Pelo presente instrumento particular, as partes abaixo qualficadas:

LICENCIANTE: ALTERNETMUSIC PRODUCAAO E GRAVACAO LTDA., empresa com sede no Municipio de SAo Paulo, Estado de Såo Paulo, na Rua Purpurina, $n^{\circ} 430$, Vila Madalena, inscrita no CNPJMF sob o $n^{0}$ 03.441.018/0001/17, neste ato representada na forma de seu estatuto social:

LICENCIADO: ALEXANDRE JENEVAIN JUNIOR, inscrita no CPF sob o residente no Municipio de luz de Fora, Estado de Minas Gerais, na Rut

Considerando que:

(a) O LICENCIADO realizará, produzira e explorard um VIOEO provisoriamente inttulado "As visóes do professor de matematica na sala de auta", a ser dirigido por Alexandre Jenevain Junior doravante designado simplesmente VIDEO, a ser realizado como trabalho academico do curso de mestrado em Educaçalo Matematica na Unigorsidade Federal de Juzz de Fora (UF.JF)

(b) A LICENCIANTE of titular dos direltos patrimoniais fonograficos of ou de negociaclo sobre as obras relacionadas no Anexo l: doravante designadas aimplesmente FONOGRAMA; e

(c) O LICENCIADO tem interesse em udizar o FONOGRAMA acima mencionado no viDEO incicado no Considerando (a)

Resolvem as partes ajustar o presente instrumento, de acordo com as clausulas a condiçen a seguir exposas

CUAUSULAI

O presente instrumertio tem como objeto o licenciamento de direitos de sincronizacto do FONOGRAMA sem carbier de exclusividade, para uticuacho no VibEO.

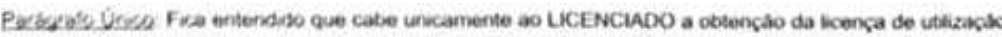

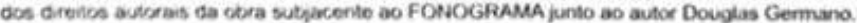

CLAUSULAH

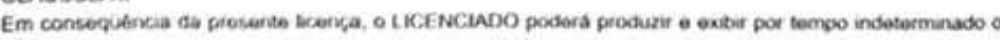

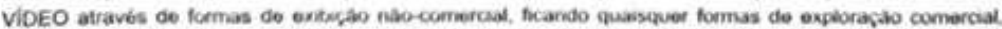

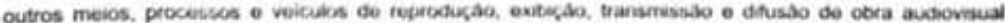
existentes ou que ventiam a exster. no brasd e no Extenor, sujeitos a obtencato se nova autoricaça.
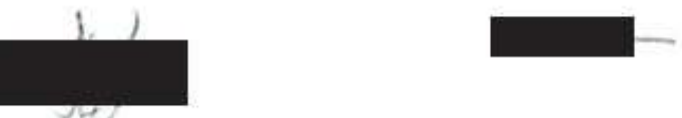

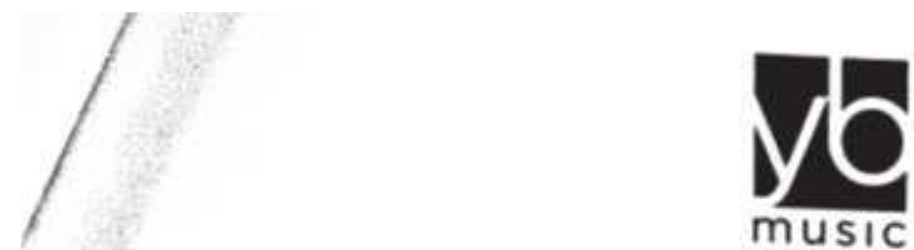

CLAUSULA III O presente bicenciamento de direitos se da em carater náo-oneroso, observadas as limitapdes descritas na
CLAUSULA II acima. Pardgrafo Únice o LICENCIADO compromete-se, ainda, a fazer constar dos creditos do viDEO a inscricalo
constando respectivamente o titulo da müsica, artistaintêrprete, autores editora.

CLAUSULAN A presente autorizacalo es especifica, nominal o intransferivel, quanto ao FONOGRAMA e VíEO aqui espe-
cificados.

\section{CLAUSULAV}

O presente contrato obriga as partes e seus herdeiros e sucessores e nao podera ser transferido nem alterado senbo mediante instrumento escrito.

\section{CLAUSULAVI}

Fica eleito o Foro da cidade de Săo Paulo, com expressa renùncia de qualquer outro, por mais priviegiado que seja. para nele serem discutidas as questides emergentes da presente contratacla.

E, por estarem justas e contratadas as partes assinam o presente contrato em 02 (duas) vias de igual teor e forma, para um 30 efeito, na presenca de duas tostemunhas para que produza seus efeitos legais.

Slio Paulo, 20 de janeiro de 2020
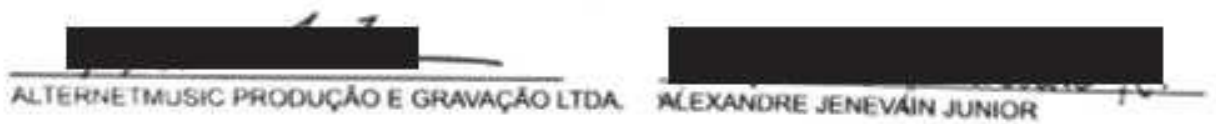

Testernunhas:
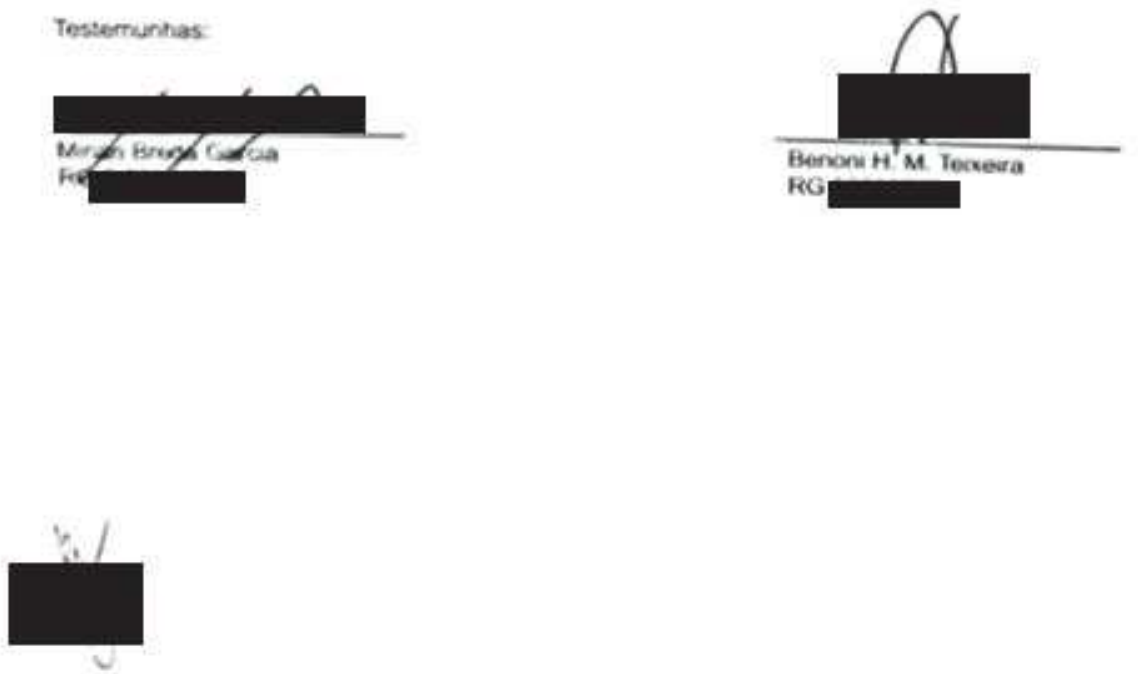
music

ANEXOI

RELACAO DE FONOGRAMAS LICENCIADOS PARA O VIDEO INTITULADO "AS VISOES DO PROFESSOR DE MATEMÁRICA NA SALA DE AULA"

\begin{tabular}{|c|c|c|c|c|}
\hline ISRC & Titulo & Artista & Autor(es) & Editora \\
\hline BRGK41500002 & $\begin{array}{c}\text { Maria da Vila Matide (Porque se a } \\
\text { da Penha é brava, imagine a da Vila } \\
\text { Matilde) }\end{array}$ & Elza Soares & Douglas Germano & $\begin{array}{c}\text { Direto como } \\
\text { Autor }\end{array}$ \\
\hline
\end{tabular}
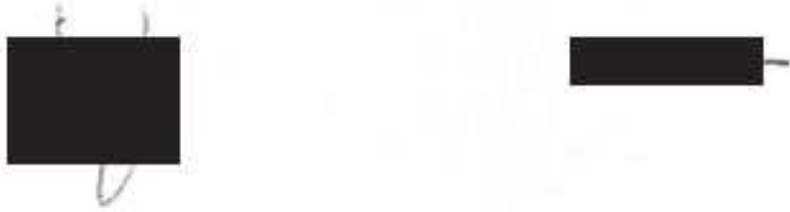

Criolo - Etérea 


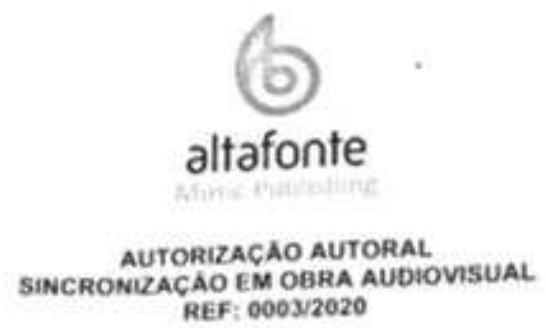

POMMELO DISTRIBUiCOES E EDTORACOES LTDA - ME NOb o CNPJ 15.811.6650001-52 - Rua iperoig. 756 , Petdizes SA0 Paylo SP CEP 05016-000 desinnada EOITORA na qualdade de mandatana dos diretos autorais da(s) OBRA(S) citadas no ANEXO I desta autorizaçio, autorua a suncronizaçao sem ônus e sem exclusividade. da(s) madsma(s) ną CBRA AUDiOVISUAL abaoxo mencionada, medianto as. seguintes condipbes:

OBRA AUDIOVISUAL; As visóes do professor de matematica na saia de aula PRODUTOR Alexandre Jenevain Junior

CNPJ /CPF:

ENDERECO

a) Qualquer texto a ser inserido na molodia que venha a alterar a letra original nâo ế permitida sem a prévia anuéncia da EDITORA.

b) A aprovaçalo dada neste instrumento refore-se apenas acs direitos de sincronizaçăo da(s) OBRA(S) ctadas no ANEXO I com a OBRA AUDIOVISUAL, sendo que os direitos de execupào publica nabo estio sendo liberados, devendo os responsaweis etetuarem o pagamento destes direitos sempro que necessario ao ECAD (Escritorio Central de Atrecadacalo e Distribuiçlo):

c) Esta sutorizaça nalo exime o PRODUTOR de ser o único e exclusivo responsalvel pelo texto da OBRA AUDIOVISUAL perante qualquer autoridade;

d) Esta autorizaçào é vallida para o Brasil e exterior.

e) Esta autorizaça e restrita a OBRA AUDIOVISUA, através da exibiço pelas midias YOUTUBE / REDES SOCIAIS, podendo ser utilizada para criacklo de produtos de divulgaça desde que sempre restntos â OBRA AUDIOVISUAL:

f) Esta autorizaçio 6 vátida peio periodo de proteçào legal da obra:

9) A utilzaçlo da(s) OBRA(S) objeto desta autorizaçâo somente podera(âo) ser difundida(s) nas midias citadas na alinea "e)" durante a vigencia desta autorizaçbo;

h) Esta autcrizacào refere-se exclusivamente a parte relativa aos direitos autorais controlados pela EOITORA, devendo o PRODUTOR liberar os direitos dos demais autores se houver, bem como a utilizagao do fonograma diretamente com os titulares dos direitos de produtor fonografico se necessário:

i) Compromete-se o PRODUTOR a entregar a EOITORA, em decorrência desta autorizaça, uma cópia da obra audionsual para seus arquivos, sendo vetada sua utilizaçáo pela EDITORA para quaisquer outros fins:

i) Obriga-se a PRODUTOR a entregar em ate 30 dias da assinatura desta autorizaçalo a respectivs "cue. sheer' da OBRA AUDIOVISUAL: k) Obriga-se o PRODUTOR a mencionat nesta OBRA AUDIOVISUAL, os créditos relativos ao titulo da
OBRA(S), autor(es) e EDITORA:

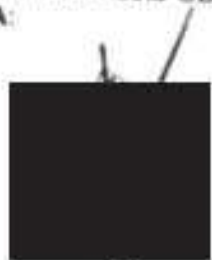


1) Eege-se o toro da codade de Sap Pavo gara acbes judicia que decorrerem desta ausonzacbo

Sao Paus, 31 de janero de 2020

POMMELO DISTRIBUICOES E EOITORACOES LTOA - ME

DE ACORDO
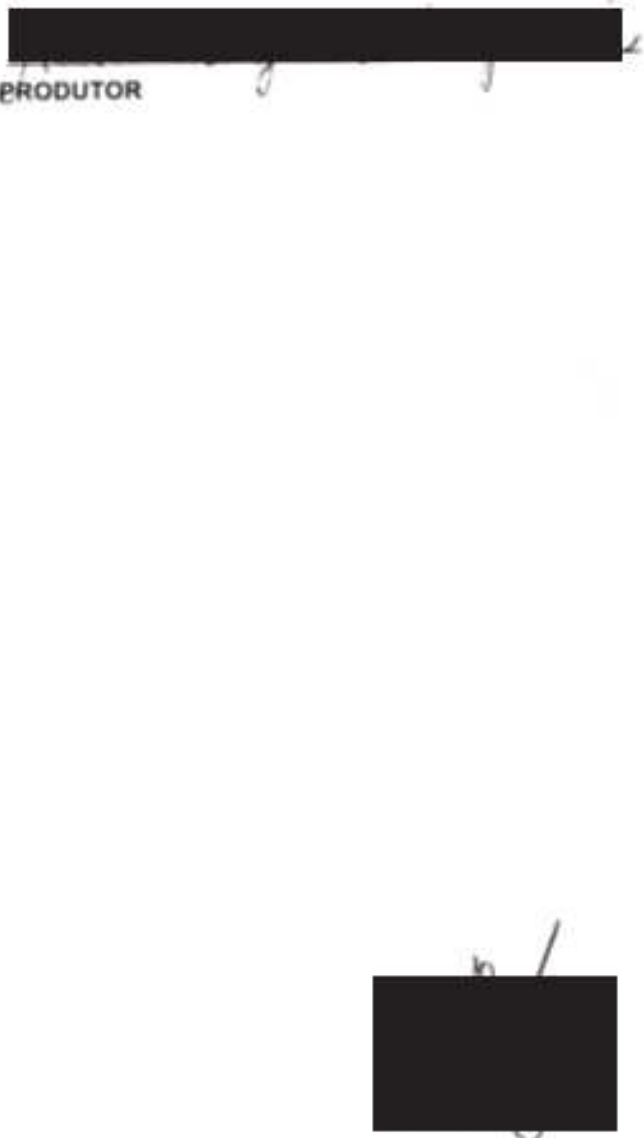

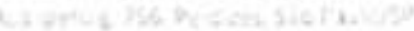




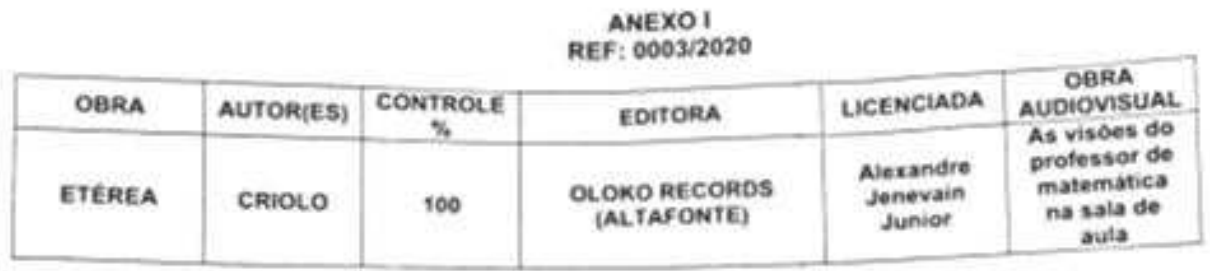

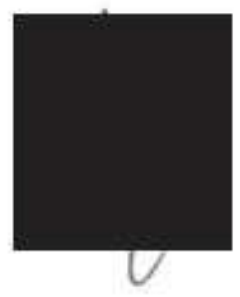

João Gama part. Mc Xuxu - Às Escuras 


\section{TERMO DE AUTORIZAÇÁO DE USO DE MÚSICA MESTRADO PROFISSIONAL EM EDUCACÄO MATEMÁTICA}

As. tranas

Neste ato, e para todos os fins de direito, autorizo o uso da minha obra musical intitulada para fins de pesquisa e divulgaçă do trabatho do mestrando Alexandre Jenevain Junior na producsio do seu documentario na instituiçāo Universidade Federal de Juiz de Fora - UFJ, em caráter definitivo e gratuito.

A obra poderá ser reproduzida: parcial ou total em apresentaçăo audiovisual, çōes para fins acadêmicos $\mathrm{e}$ festivais com ou sem premiaçōes remuneradas

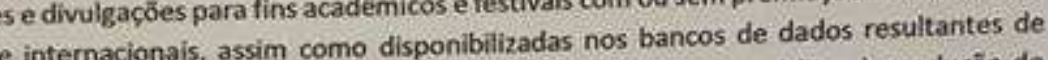
nacionals e internacionais, assim como disponibilizadas nos bancos de códitos à produçio do pesquisas e em outras midlas futuras, fazendica

Por ser esta a expressão de minha vontade, nada terei a reclamar a titulo de direitos autorais conexos à obra ou qualquer outro.

$$
\text { Tuiz de Fora Og de agasto de } 2012
$$

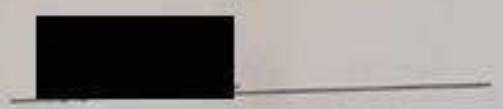

Assinatura

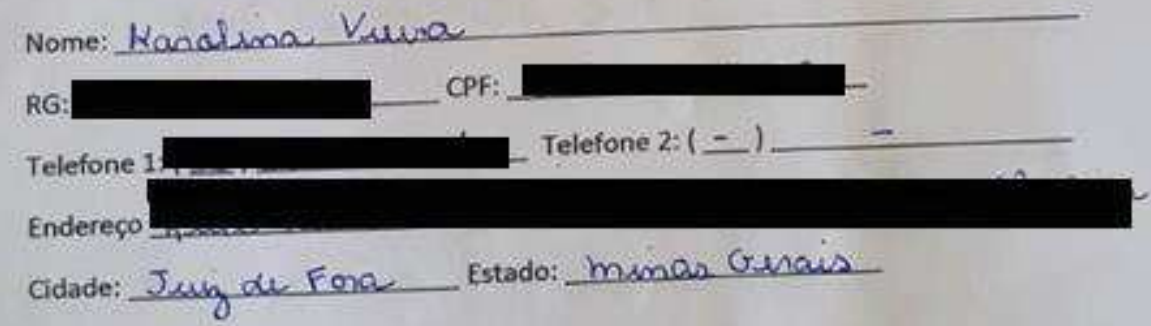




\section{TERMO DE AUTORIZAÇÃO DE USO dE MÚSICA MESTRADO PROFISSIONAL EM EDUCACĞO MATEMÁTICA.}

Neste ato, e para todos os fins de direito, autorizo o uso da minha obra musical intitulada

Ao Enowitas para fins de pesquisa e divulgaş̄o do trabalho do mestrando Alexandre Jenevain Junior na produçäo do seu documentário na instituição Universidade Federal de Juiz de Fora - UFJF, em carster definitivo e gratuito.

A obra poderá ser reproduzida: parcial ou total em apresentaçào audiovisual, publicaçöes e divulgaçōes para fins acadêmicos e festivais com ou sem premiaç̄es remuneradas nacionais e intemacionais, assim como disponibilizadas nos bancos de dados resultantes de pesquisas e em outras midias futuras, fazendo-se constar os devidos créditos à produça do Mestrado Profissional em Educaçäo Matemática.

Por ser esta a expressăo de minha vontade, nada terei a reclamar a titulo de direitos autorais conexos à obra ou qualquer outro.

Jusig de Fona O9 de agasto de 2019 .
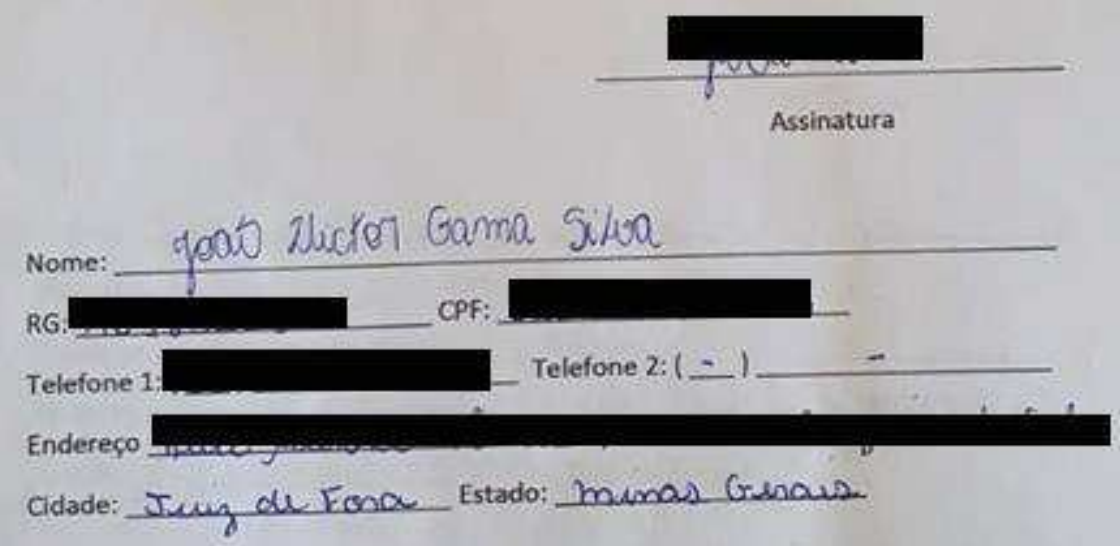

Eu Sou - WD 
Oi Alexandre,

Que legal que ele já autorizou. Como somos a distribuidora do conteúdo dele, precisamos apenas formalizar a autorização, já que nós respondemos por toda a renda gerada pelo uso da música de nosso artista. E mesmo que a autorização não gere nenhum tipo de custo para você, precisamos saber se haverá a distribuição através do YouTube ou outras plataformas

Caso seja distribuído no YouTube, precisamos seguir os seguintes passos:

1) Seja incluida na descrição do vídeo o seguinte texto:

Música "Eu Sou - WD" gentilmente cedida pela ONErpm.

2) Nos envie o link do vídeo para desabilitarmos a função de reivindicação da música e evitar que a plataforma retire seu vídeo do ar.

Um abraço,

\section{Douglas Almeida}

Head of Publishing Operations

skype: douglas.aasp

YouTube | Facebook I Instagram | Twitter

\section{Cng MUSIC IS POWER AMPLIFY IT}


Gabriela Mara

\section{TERMO DE AUTORIZAÇÃO DE USO DE IMAGEM E VOZ MESTRADO PROFISSIONAL EM EDUCAÇÃO MLATEMÁTICA} intitulada

Neste ato, e para todos os fins de direito, autorizo o uso da obra musical Siga em Frente - Gabriela Mara

divulgação do trabalho do mestrando Alexandre Jenevain Junior na produção do seu documentário na instituição Universidade Federal de Juiz de Fora - UFJF, em caráter definitivo e gratuito.

A obra poderá ser exibidas: parcial ou total em apresentação audiovisual, publicações e divulgações para fins acadêmicos e festivais com ou sem premiações remuneradas nacionais e internacionais, assim como disponibilizadas nos bancos de dados resultantes de pesquisas e em outras midias futuras, fazendo-se constar os devidos créditos à produção do Mestrado Profissional em Educação Matemática.

Por ser esta a expressão de minha vontade, nada terei a reclamar a título de direitos conexos à minha imagem e voz ou qualquer outro.

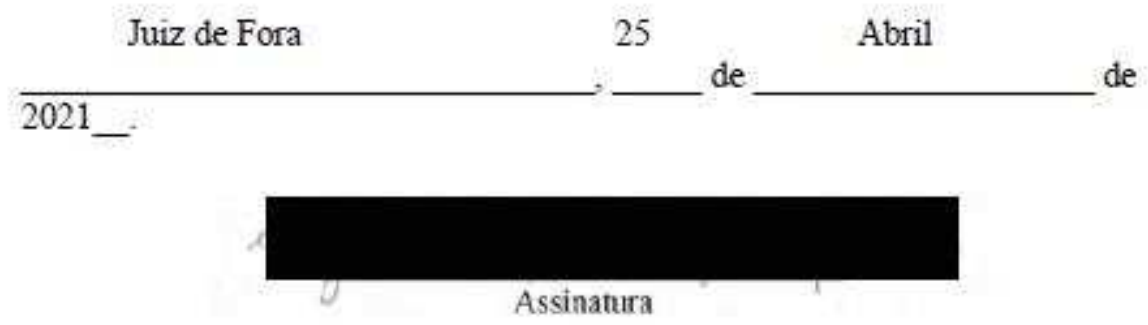

Nome: Gabriela Mara Braga de Almeida

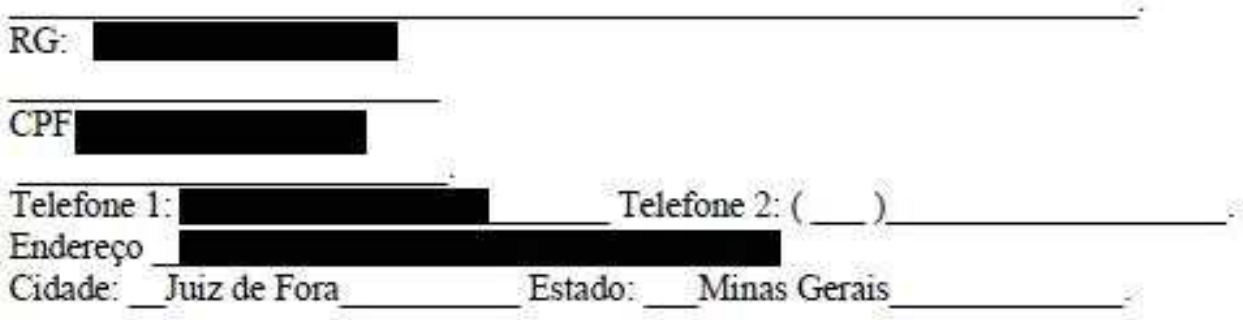

